\title{
Evolution of New Zealand's Marine Caddisflies: A Phylogenetic and Phylogeographic Assessment of the Chathamiidae (Insecta: Trichoptera)
}

\section{Alexander Peter Boast}

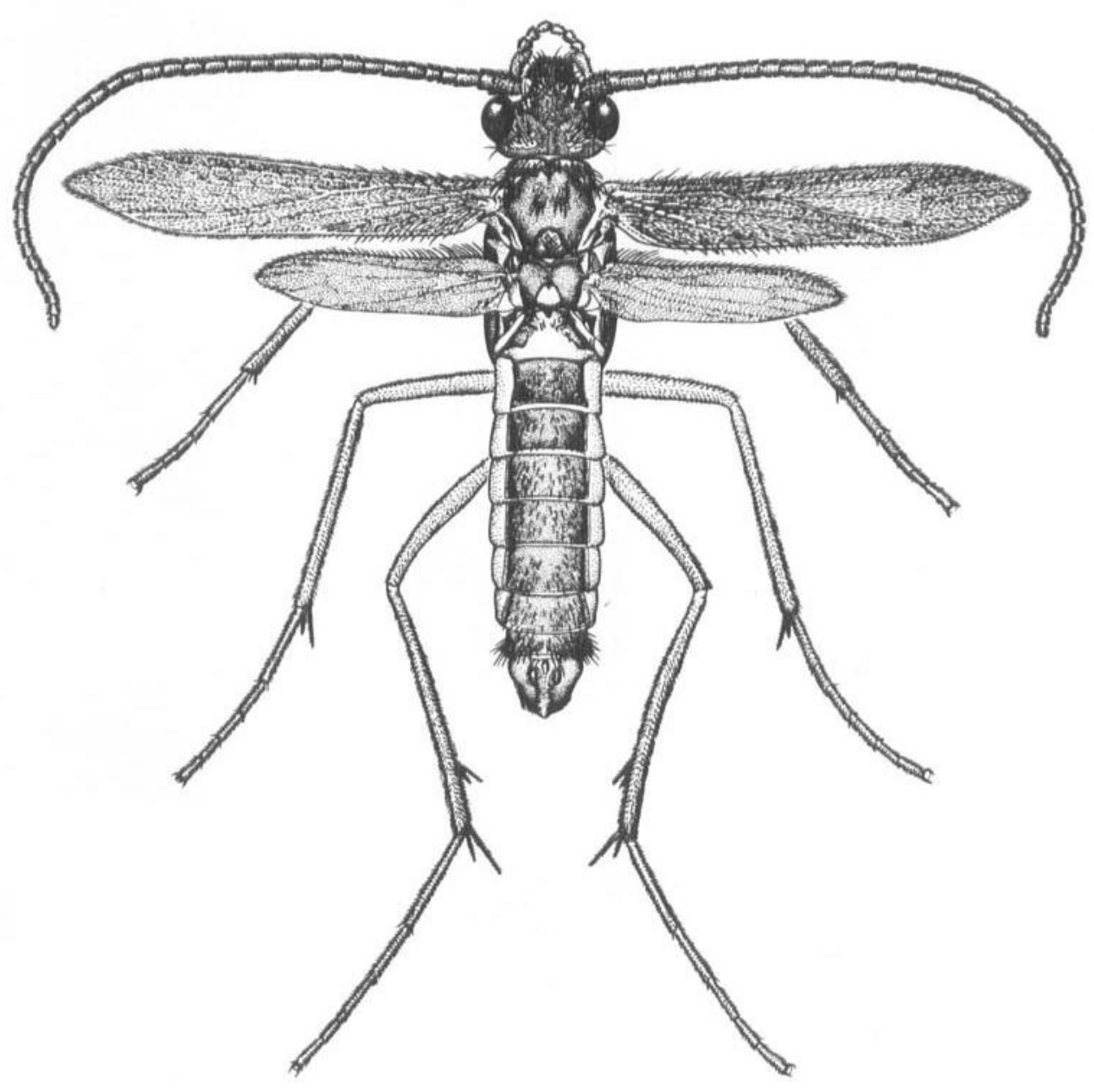

A thesis submitted in partial fulfilment of the requirements for the degree of Masters of Science in Ecology and Biodiversity.

Victoria University of Wellington.

December 2010. 


\section{Acknowledgments}

This study would not have been possible without the considerable level of assistance and contribution others have provided to this study. Firstly I would like to thank my supervisor Dr Peter Ritchie who has helped and guided me through this thesis every step of the way, almost three years in the making. Pete willingly took me on long before caddisflies even crossed my mind as a research topic, and his patience with a student in ecology attempting a thesis on genetics has been extraordinary. My co-supervisor Dr Ian Henderson has also been of invaluable assistance, not only going out of his way to collect a considerable number of samples specifically for my study and donating his own specimens, but also willingly providing his formidable expertise to shape and steer this thesis. I am indebted to you both.

I cannot thank enough those who were willing to help with my sampling in this study. I must give special thanks to Dr Alice Wells who provided me with samples collected from three different areas in New South Wales Australia. I also must thank Karen Baird for her readiness and willingness to collect for me samples from the almost untouchable Kermadec Islands, for which I am still immensely grateful to have had the fortune to have obtained! Michelle Jenkinson at Department of Conservation was of considerable help and patience for helping me to secure permission for use of the Kermadec material, of whom her and Karen both stepped out of protocol to make up for my own disorganisation! I must also extend my gratitude to the entomological society of New Zealand who provided me with a $21^{\text {st }}$ anniversary grant to facilitate my travel to the Chatham Islands for collection. I also must thank my parents Richard Boast and Deborah Edmunds, who among the endless support they both offered, were also amazingly willing to help endure sometimes interminable nights of (often unsuccessful) light trapping on obscure coasts throughout New Zealand with me. For this I must also thank my uncle, David Edmunds for his help in finding collection sites in Tauranga. This thanks also extends to two of my close friends, James McLean and Nina van der Voorn, whom endured numerous searches through streams in the remote New Zealand wilderness, including after dark on occasion, all that I might possibly obtain samples of obscure species of caddisfly!

As a student with a limited background in any genetics, without the assistance of Monica Gruber and Sebastien Rioux Paquette I would have been sorely lost in the workings on the laboratory. You two both helped out enormously, and took out much of your own time when you both had so much to do yourself, thank you. I also must thank Neville Higgison for helping with my numerous light-trap and battery issues, Lesley Milicich for helping me secure equipment, and Dr Phil Lester for allowing access to his entomology lab. I must also give (long overdue) thanks to Phil Garnock-Jones, Chris Simon, and George Gibbs who helped steer this thesis onto its current course long ago. I must also extend one special thanks to Patricia Stein who has always been of incredible assistance through my (numerous) issues of enrolment, building access and otherwise on countless occasions. I would also like to thank my fellow students and partners of the molecular ecology lab KK612, especially Surrey Scott and Brenton Hodgson who have helped out on uncountable occasions in the past. Finally I would like to thank all my friends and family, who have always been there to help me through the worst of times, I would have never completed this work without your support. 


\section{Abstract}

The Chathamiidae are an interesting family of caddisflies, unusual as all of the five known species are believed to breed entirely within the marine intertidal, comprising one of very few known marine insect groups. Additionally the family approaches almost complete endemicity status in New Zealand, and may represent an ancient lineage representative of ancient vicariance from Gondwana. However one species, the common and widespread Philanisus plebeius is also known to have a disjunct population in New South Wales Australia, hypothesised to represent a recent anthropogenic dispersal. This thesis, using DNA information, examined the Chathamiidae at varying phylogenetic levels.

Firstly the species Philanisus plebeius was incorporated into a thorough intraspecific phylogeography, including samples from both New Zealand and Australia. The population as a whole was genetically diverse, with the population divisible into two major haplogroups, each restricted to discrete geographic areas with no overlap being observed. One of these groups was restricted to just two localities in the central eastern North Island, whereas the remainder included most remaining samples from both Islands of New Zealand, and also Australia. All Australian samples were found to comprise a single haplotype, differing by a single base pair from the most common haplotype in New Zealand. It was decided that the Australian population therefore represents a recent dispersal event from New Zealand, although unless the Australian haplotype remains undiscovered in New Zealand the level of divergence found is not congruent with a human introduction. One sequence intermediate between the two major haplogroups was identified from a single haplotype from Tauranga. It seemed that much of the population of Philanisus plebeius has been affected by recent demographic expansion, likely due to the effects of the last glacial maximum (LGM).

The five species of the Chathamiidae were then analysed in a phylogeny. It was found that the genus Chathamia was polyphyletic, with the species $C$. integripennis nested within the genus Philanisus. The remaining species, C. brevipennis from the Chatham Islands, was basal to all the remaining members of the family. A strict molecular clock found a recent Pleistocene age (roughly $0.5 \mathrm{Ma})$ for divergence of the Kermadec Island species Philanisus fasciatus, and a PliocenePleistocene age (roughly $3 \mathrm{Ma}$ ) for the Chatham Island species Chathamia brevipennis. For a comparison with the species $C$. brevipennis, the other Chatham Island caddisfly taxa Oecetis chathamensis, and Hydrobiosis lindsayi were compared with New Zealand relatives; indicated to have late and early Pleistocene ages respectively. A short sequence of the gene COI was amplified for the species Philanisus mataua, however this was found to contain two sequences reflecting either heteroplasmy or sample contamination, inhibiting confident phylogenetic placement. Additionally a larval sample from Sydney was demonstrated to represent $C$. integripennis, recorded outside of Northern New Zealand for the first time. Finally the Chathamiidae was included in a higher level phylogeny with related families, and was show to comprise a monophyletic group, sister to the Australasian family of the Conoesucidae. A relaxed molecular clock estimated a Cretaceous (roughly $90 \mathrm{Ma}$ ) age for the Chathamiidae, congruent with a vicariant age in New Zealand. 


\section{Contents}

\section{Chapter One: General Introduction:}

1.1 The Chathamiidae, the world's only marine caddisflies 1

1.2 An overview of caddisflies and their biodiversity in New Zealand 5

$\begin{array}{lll}1.3 & \text { Marine Insects } & 8\end{array}$

1.4 The natural history and biogeography of New Zealand 10

1.5 Aims and structure of this thesis 15

$\begin{array}{lll}1.6 & \text { References } & 16\end{array}$

Chapter Two: Genetic structure of an intertidal insect: phylogeography and cryptic speciation of the marine caddisfly Philanisus plebeius (Trichoptera: Chathamiidae) from New Zealand and Australia.

$\begin{array}{lll}2.1 & \text { Introduction } & 22\end{array}$

2.1.1 The study organism: Philanisus plebeius. 24

$\begin{array}{lll}2.1 .2 & \text { The Aims } & 26\end{array}$

2.2 Materials and Methods 27

$\begin{array}{lll}\text { 2.2.1 Sample Collection } & 27\end{array}$

2.2.2 DNA sequencing and alignment 28

$\begin{array}{lll}2.2 .3 & \text { Genetic analyses } & 28\end{array}$

$\begin{array}{lll}2.3 & \text { Results } & 30\end{array}$

2.3.1 Sample Collection $\quad 30$

$\begin{array}{lll}2.3 .2 & \text { Sequence data } & 31\end{array}$

2.3.3 Haplotypic and phylogenetic structure 31

2.3.4 Phylogeographic Structure 32

2.4 Discussion 34

2.4.1 Internal Relationships of Philanisus plebeius 34

2.4.2 Phylogeography of Haplogroup A \& B localities and origin of the
Australian population

2.4.3 Cryptic diversity in P. plebeius: the origin and identity of haplogroup C 39

2.4.4 Inferred molecular ecology of Philanisus plebeius and conclusions.

$\begin{array}{lll}2.5 & \text { Figures } & 46\end{array}$

$\begin{array}{lll}2.6 & \text { References } & 60\end{array}$ 
Chapter Three: Phylogeny of the Chathamiidae and origins of the species Hydrobiosis lindsayi and Oecetis chatamensis (Insecta: Trichoptera) with regard to the formation of the Kermadec and Chathams Islands:

$\begin{array}{lll}3.1 & \text { Introduction } & 70\end{array}$

$\begin{array}{lll}3.1 .1 & \text { The Chatham Islands } & 72\end{array}$

$\begin{array}{ll}\text { 3.1.2 The Kermadec Islands } & 75\end{array}$

$\begin{array}{lll}3.1 .3 & \text { Aims } & 76\end{array}$

3.2 Materials and Methods $\quad 76$

3.2.1 Sample collection $\quad 76$

$\begin{array}{ll}\text { 3.2.2 DNA sequencing and alignment } & 76\end{array}$

$\begin{array}{lll}\text { 3.2.3 Genetic analysis and phylogenetic reconstruction } & 77\end{array}$

$\begin{array}{ll}\text { 3.2.4 Estimating divergences and molecular clock } & 79\end{array}$

$\begin{array}{lll}3.3 & \text { Results } & 79\end{array}$

$\begin{array}{lll}\text { 3.3.1 } & \text { Sample collection } & 79\end{array}$

$\begin{array}{lr}\text { 3.3.2 } & \text { Sequences and sequence statistics } \\ 3.3 .3 & 80\end{array}$

3.3.3 Phylogency of the Chathamiidae 81

3.3.4 Phylogenetic placement of Philanisus mataua 82

3.3.5 Phylogeny of Hydrobiosis and Oecetis $\quad 82$

3.3.6 Divergences and Age assumptions 83

3.4 Discussion $\quad 83$

3.4.1 Phylogeny and taxonomy of the Chathamiidae 83

3.4.2 Phylogenetic placement of Hydrobiosis lindsayi and Oecetis chathamensis $\quad 86$

3.4.3 Philanisus fasciatus and the Kermadec Islands 87

3.4.4 Chathamia brevipennis, Oecetis chathamensis, Hydrobiosis lindsayi and
the Chatham Islands

$\begin{array}{lll}3.5 & \text { Figures } & 92\end{array}$

$\begin{array}{llr}3.6 & \text { References } & 104\end{array}$

Chapter Four: Are New Zealand's marine caddisflies a 'ghost of Gondwana'? Phylogenetic placement of the Chathamiidae

$\begin{array}{lll}4.1 & \text { Introduction } & 115\end{array}$

$\begin{array}{ll}\text { 4.2 Materials and Methods } & 119\end{array}$

$\begin{array}{lll}\text { 4.2.1 Taxon sampling } & 119\end{array}$

$\begin{array}{ll}\text { 4.2.2 Alignment, phylogenetic analysis and molecular clock } & 121\end{array}$

$\begin{array}{lll}4.3 & \text { Results } & 123\end{array}$

$\begin{array}{lll}\text { 4.3.1 Phylogenetic Analysis } & 123\end{array}$

4.3.2 Molecular Clock \& Saturation Tests 123 
4.4 Discussion

4.5 Figures

4.6 References

\section{Chapter Five: General Discussion and Conclusions}

5.1 Major results of this study

5.2 Limitations of this study and future research

5.3 References 


\section{List of Figures}

2.1
Collection records of Philanisus plebeius

Mismatch distribution chart of pairwise distances in Philanisus plebeius

Network Analysis of haplotypes in Philanisus plebeius $\quad 54$

Maximum parsimony tree of haplotypes of Philanisus plebeius

Maximum likelihood tree of haplotypes of Philanisus plebeius 56

Bayesian tree of haplotypes of Philanisus plebeius $\quad 57$

Map of haplotypes in New Zealand and collection sites 58

Inferred past and present distributions of Philanisus plebeius

Estimated distribution of the Chathamiidae in New Zealand 92

Chromatogram sample of the Philanisus mataua sequence 96

Maximum likelihood tree of the Chathamiidae based on COI 97

Maximum parsimony tree of the Chathamiidae based on COI 98

Bayesian tree of the Chathamiidae based on COI 99

$\begin{array}{ll}\text { Bayesian tree of the Chathamiidae based on 16S } & 100\end{array}$

Neighbour-joining tree of Oecetis 101

Bayesian analysis tree of Hydrobiosis 101

Neigbour-joining trees regarding to the placement of Philanisus mataua. $\quad 102$

$\begin{array}{ll}\text { Bayesian analysis tree of the Chathamiidae and ougroups. } & 131\end{array}$

Bayesian tree as analysed in BEAST $\quad 132$ 


\section{List of Tables}

2.1 List of all samples used for sequencing in Chapter Two and collection details. 47

2.2 Primers used for amplification and sequencing in Chapter Two. 48

2.3 All Philanisus plebeius haplotypes found and frequency in each locality. 49

$2.4 \quad$ List of all Philanisus plebeius haplotypes found in this study and base pair composition. 50

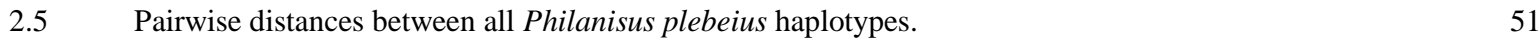

2.6 Mean distances between and within groups, and within all of Philanisus plebeius. 52

2.7 List of sequence statistics calculated for between Philanisus plebeius haplotype groupings. 53

2.8 List of all AMOVA statstics calculated in Arequin.

3.1 Full list of taxa, specimens and sequences used in Chapter Three. 93

3.2 List of primers used for amplification and sequencing in Chapter Tree. 95

3.3 Interspecific divergence means for COI for all species sequenced for this study (except P. mataua) 95

3.4 Intraspecific pairwise divergence means for COI between species of the Chathamiidae 95

3.5 Intraspecific pairwise divergence means for 16S between species of the Chathamiidae 95

3.6 Intraspecific pairwise divergences between all Hydrobiosis and Epdercivalia sequences 96

$\begin{array}{lll}3.7 & \text { Estimated age divergences for relevant taxa in Ma as inferred by molecular clocks. } & 103\end{array}$

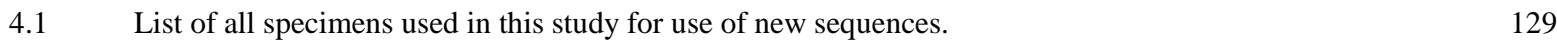

$\begin{array}{lr}\text { 4.2 List of all primers used for amplification and sequencing in Chapter Three. } & 129\end{array}$

$\begin{array}{lr}4.3 & \text { List of all sequences used in Chapter Three. } \\ \end{array}$ 


\section{Chapter One: General Introduction}

\subsection{The Chathamiidae, the world's only marine caddisflies.}

New Zealand is well known for its unique and apparently ancient biota, and several lineages of its flora and fauna have undergone evolutionary trajectories not seen anywhere else in the world. One particularly interesting and little known group, are a small family of case-making caddisflies, the Chathamiidae. Chathamiid caddisflies are especially unusual as almost uniquely among all insects they develop entirely within the intertidal zone of the marine environment, thus representing a rare case of a marine insect. Importantly, the Chathamiidae are also one of very few insect families that approach endemicity status to New Zealand, and thus potentially represent one of the oldest members of the native fauna. As the assumed antiquity or Gondwanan element of New Zealand's biota is now being questioned, groups such as this are of particular importance in contemporary debates. Thus this group represents an especially unique and interesting case for a study in evolutionary biology in two distinct ways. Breeding in seawater, the family is unusually biogeographically and ecologically among insects; and also may perhaps represent a small group of significant or even Gondwanan age in New Zealand.

Chathamiids are medium sized (10-5mm wing length), pale-brown caddisflies. They can be recognised by characteristic 5 jointed maxillary palpi and a hairy facial protrusion of the males, and also distinctive large ovipositors found on the females (Riek 1976, Ward 1994). To date five species of Chathamiid caddisflies have been identified; Chathamia brevipennis, C. integripennis, Philanisus fasciatus, P. plebeius and P. mataua (Tillyard 1925, Riek 1976, Ward 1995). All species are native to the greater New Zealand region. However the common species Philanisus plebeius has also been known to inhabit the coasts of New South Wales, Australia since identification by Hudson (1904) and has been confirmed as the same species from New Zealand (Riek 1970). This is the only known incidence of any of New Zealand caddisfly species being also found in Australia (out of over 240 species); as far as known all remaining species are fully endemic (Collier 1993). This, combined with 
its unusual marine habitat as well as the comparatively localised population in Australia (none are known from Victoria or Tasmania for example) has raised the possibility that the Australian population is an accidental human introduction (Gibbs 2005), although an Australian origin has also been suggested (Winterbourne \& Anderson 1980).

Philanisus plebeius Walker was first described from Christchurch (Riek 1976) in 1858. An 1858 record from the Austrian scientific expedition Novara 1857-9 is presumably the same sample, first given separate family status in the Philanisidae by Mosely \& Kimmins (1953). Chathamia brevipennis was described from a single brachypterous (short-winged) male from Kaingaroa, Chatham Island by Tillyard (1925), from which it was assigned to the Rhyacophilidae under the subfamily Chathamiinae. C. brevipennis was recognised as sharing characteristics with P. plebeius by Wise (1965), who transferred the species to the Philanisidae. Riek (1976) acknowledged insufficient difference between the two genera to warrant separate subfamily status. Chathamiidae has nomenclatural priority over the Philanisidae.

A new species of Philanisus; P. fasicatus was identified from Raoul Island of the Kermadecs in 1967, morphologically distinct from P. plebeius. Another species was also identified from Northern New Zealand, which Riek (1976) described as a new species of Chathamia, C. integripennis, although assigning the species to the genus based on a 'similarity' to $C$. brevipennis. The most recently described taxon; Philanisus mataua, was first recognised from male specimens collected in 1993 (Ward 1994) and described to species by Ward (1995). Female P. mataua remain unknown and may be indistinguishable from $P$. plebeius. $C$. brevipennis and $P$. fasciatus to date are only known from Chatham and Raoul Islands respectively, and it is unknown whether they are more broadly distributed in their respective island groups. $C$. integripennis and $P$. mataua appear restricted to the northern North Island (although P. mataua is evidently rarer, and likely frequently confused with the similar and much more common P. plebeius). P. plebeius is widely distributed through most of mainland New Zealand and offshore islands including the Three Kings Islands, although perhaps absent on the South and West Coasts of the South Island, and much of the West coast of the North Island (although 
this also likely reflects a lack of sampling). In Australia the species is not known to occur North of Sydney, nor the coasts of Victoria or Tasmania and thus is not indicated to be widespread there.

Marine case-making caddisfly larvae have been identified from Chatham Island and thus likely those of $C$. brevipennis (Riek 1976), otherwise all known Chathamiid larvae and general ontogeny (such as ovipostion, larval habitat and pupation) are only known definitively from $P$. plebeius. Larvae of the remaining three species remain undescribed (larval caddisflies are often impossible to distinguish to exact species) although are still assumed to be marine in nature based on phylogeny and the coastal nature of the adults. Larvae can be found in the intertidal zone towards the low tide mark, most abundantly in sheltered, open rock pools on rocky coasts, although they have also been associated with seagrass beds in soft sediment, foraging us much as $2 \mathrm{~m}$ underwater (Riek 1976). This continual existence in full seawater is the highest salinity (35\%) tolerated by any caddisfly (Kefford et al. 2004, Flint \& Giberson 2005). Larvae build cases from nearby material, usually coralline algae, and are most commonly associated with the calcareous alga Corallina although they are also found on a variety of algal species and seagrass (Allan 1958, Riek 1976, Winterbourne \& Anderson 1980, Taylor \& Cole 1994, Taylor \& Steinberg 2005). The diet of the larvae is herbivorous, and in spite of a common association with Corallina, gut content has been found to comprise primarily of non-calcerous species (Winterbourne \& Anderson 1980). Larvae enclose their cases and pupate in algae near the shoreline in late spring, completing their entire development in the sea (Cowley 1976, Riek 1976). Adults emerge presumably mostly from late Spring to Summer and are present year-round, found flying all months of the year except for June-July (Riek 1976, Anderson \& Lawson-Kerr 1977, Ward et al. 1996).

It was discovered that $P$. plebeius also demonstrate an unsual parasitism on Asterinid starfish, first described in Parvalustra (formerly Patiriella) exigua in Australia (Anderson et al. 1976) and later described in the related Patiriella regularis in New Zealand (Winterbourne \& Anderson 1980), both the most common starfish in their respective regions. All Chathamiid female adults possess a large and distinct ovipositor (this is not found in any related family), which had been found in $P$. plebeius to forcibly deposit egg masses within the host's body cavity. It is assumed the host is largely 
used as a stable environment for completing embryonic development and the first-instar larvae apparently leave with minimal effect (Anderson \& Lawson-Kerr 1977). This is almost certainly the only echinoderm-insect symbiosis known, and also a very rare case of parasitic behaviour in Trichoptera excepting a few known Hydroptilidae which are Parasitoids on other caddisfly larvae (Wells 1992, 2005).

It is currently unknown whether this behaviour is obligate or essential for the caddisfly's development, or whether this is simply opportunistic or facultative behaviour. Similarly it is not known whether this behaviour is typical of other Chathamiidae (although since all species have the ovipositor it is certainly plausible), and whether these species are the only starfish exploited. In New Zealand Patiriella species are present wherever representatives of Chathamiidae are found including P. regularis and $P$. mortenseni throughout New Zealand and the Chatham Islands (Young 1929, McKnight 1968, O’Loughlin et al. 2002), and P. oliveri in the Kermadec Islands (Pawson 1961), suggesting this behaviour may be commonplace. Evidence supporting oviposition amongst Corallina in Northern New Zealand was presented by Leader \& Bedford (1979), although this may have been eggs of C. integripennis (Winterbourne \& Anderson 1980). Repeated washes of algae by Winterbourne \& Anderson (1980) also found very low numbers of eggs although this contrasted with the much higher numbers found in starfish, who also found that the hosts apparently ejected undeveloped eggs along with larvae during in-vitro trials. It is unclear how an association or dependence on a host might affect Chathamiid biogeography, dispersal and abundance patterns. It was reasoned by Winterbourne \& Anderson (1980), as since Parvalustra exigua in Australia is more abundant and lies closer to shore than Patiriella regularis in New Zealand that this behaviour and thus the species itself are more likely to have evolved there. This conclusion is unlikely considering that most species of the family are restricted to New Zealand, and it is currently more parsimonious to assume a non-Australian origin for P. plebeius and certainly for the remaining Chathamiid species.

Aside from their unusual ecology, the Chathamiidae are also morphologically distinct and for this reason have been given full family status, supported by molecular studies. Riek (1976) suggested the family as being closest to the diverse worldwide family Leptoceridae (superfamily Leptoceroidea). 
Subsequent phylogenies by Kjer et al. $(2001,2002)$ based on $28 \mathrm{~S}$ nuclear data however place the Chathamiidae within the superfamily Sericostomatoidea, with some trees showing a probable relationship to the other Australasian families Calocidae, Helicophidae and Conoesucidae in particular. This has been supported by morphology (Frannia \& Wiggins 1997, Henderson \& Ward 2007). More recent work on $16 \mathrm{~S}$ mitochondrial data however indicated the Chathamiidae sharing a weakly supported relationship with the Leptoceridae and the Helicopsychidae (Johanson et al. 2009, Johanson \& Malm 2010). Grimaldi \& Engel (2005) also created a phylogenetic tree based on Kjer et al. (2001, 2002) and also Frania \& Wiggins (1997), and using fossil material as a calibration tentatively dated the Chathamiidae lineage originating roughly $140 \mathrm{Ma}$ in the late Cretaceous, predating New Zealand's rifting by over 60 million years. While this age remains tenacious and may well be a considerable overestimate, it nevertheless does demonstrate the possible evolutionary importance of this taxon.

\subsection{An overview of caddisflies and their biogeography in New Zealand.}

Caddisflies are generally small, moth like holometabolous insects, which comprise the order Trichoptera. Adults are usually drab, short lived, nocturnal, and display very little morphological diversity between species, although some species are diurnal and brightly coloured (Holzenthal et al. 2007). All species with some very rare exceptions (e.g. Anderson 1967, Hayashi et al. 2008) have fully aquatic larvae, the best known of which are the typical "caddis-worms" of the Integripalpia which use silk to produce a wide variety of portable cases. However throughout the order, larvae display number of ecological forms, including free living predators, retreat-dwellers and net-spinners, collectively well known as 'underwater architects' (Wiggins 2004). Comprising some 13,000 known species in 46 described families, caddisflies are among the more ecologically important of all freshwater invertebrates, comprising higher species diversity than the other fully aquatic insect orders of the Ephemeroptera, Odonata, Plecoptera and Megaloptera combined (de Moor \& Ivanov 2006, 
Holzenthal et al. 2007). Among fully aquatic insect taxa only Culicomorphid flies (Diptera, subclass Nematocera) outnumber them (Grimaldi \& Engel 2005).

The Trichoptera is also of some evolutionary importance, whose relationship to the butterfly and moth order of the Lepidoptera forming the superorder Amphiesmenoptera, is perhaps among the most widely accepted higher taxonomic groupings in entomology (Kristensen 1975, 1991, 1995, Wheeler et al. 2001, Whiting 2002). The relationship between the two groups is well supported by a number of morphological synapomorphies, including modification of salivary glands into silk producing organs in the larvae, heterogametic females, a double looping of the anal veins on the forewings, and dense setae on the wings (modified into scales in the Lepidoptera). The two probably evolved from the Necrotaulidae, an early Mesozoic insect group known from fossils as early as Triassic in age (Willman 1989, Ivanov \& Sukatsheva 2002), and the two orders themselves likely diverged between the Triassic and Jurassic periods.

Traditionally the Trichoptera has been divided into at least three suborders, roughly congruent with life-history of the larvae. The Annulipalpia is comprised of retreat making and net spinning larvae and the Integripalpia comprises all the true case making species. A third group the 'Spicipalpipa' has also been proposed, comprising a number of free living and shelter making caddisfly families now recognised as a basal paraphyletic grade of the Integripalpia (Frannia \& Wiggins 1997, Kjer et al. 2001, 2002). The earliest definitive fossil Trichopteran is of early Jurassic in age (180-185 Ma, Ansorge 2002) although some fully modern families, especially the Philopotamidae (Annulipalpia) are well represented from the mid Jurassic onwards suggesting the family may have diverged earlier still in the Triassic. The earliest fossil larval cases appear in the early to mid-Jurassic (Sukatsheva 1985, 1994), although remain rare until an apparent radiation in the Cretaceous, comprising a number of taxonomically unidentifiable trace-fossil 'ichnospecies' (Ivanov \& Sukatsheva 2002). Few fossil Integripalpia adults or larvae of Mesozoic age are known, although specimens up to early cretaceous in age can be assigned to modern families (Sukatsheva \& Jarzembowski 2001, Ivanov \& Sukatsheva 2002, Ivanov 2006, Ponomarenko et al. 2001). In this regard the Trichoptera represents a deeply divergent and ancient group, significantly more so than the 
related Lepidoptera which are not believed to have undergone major radiation until the Late Cretaceous (Grimaldi \& Engel 2005).

The old age of the Trichoptera may be represented in their contemporary biogeography, as a number of groups are restricted to modern fragments of Laurasia (North America and Eurasia) or Gondwana (South America, Antarctica, Australia, Africa, India, Madagascar and New Zealand), suggestive of ancient patterns of vicariance. This is perhaps best reflected in the closely related 'Spicipalpian' families of the Rhyacophilidae and the Hydrobiosidae, each almost entirely restricted to Laurasian and Gondwanan fragments respectively. This pattern is also particularly well demonstrated in the Integripalpia, of the 30 established case making families, 13 are mostly Northern in distribution and 14 are mostly Southern (de Moor \& Ivanov 2008). Several of these families are found between the regions although remain species (and particularily genera) poor far from their presumed vicariant landmasses. Only the Leptoceridae, Calamoceratidae and Helicopsychidae are well represented in both hemispheres. All Annulipalpian families are essentially found worldwide, which may indicate all families were well established by the time of major continental rifting, or that the groups have since dispersed widely.

New Zealand is characterised by a rich diversity of caddisflies, comprising over 240 species in 15-16 families (Ward 1967), and all species excepting the marine Philanisus plebeius are believed endemic (Collier 1993). A number of normally large or important families are species poor or absent, such as the Hydroptilidae which is represented by only 19 species in 3 genera, compared to over 140 species in 15 genera in Australia (Ward \& Henderson 2004). Additionally diversity is unusually disproportionate, with one family, the Hydrobiosidae comprising roughly half of all known species (over 100 species in ten genera, with several undescribed, and all genera also being endemic). Other significant families include the Hydropsychidae, Philopotamidae, Leptoceridae, Coneoesucidae and the Oeconesidae although a number of southerly 'gondwanan' families are present in low diversity including the Calocidae, Helicophidae, Philorheithridae, Kokirridae and the Chathamiidae. The Chathamiidae and Oeconesidae are of particular interest as both groups have a predominantly New Zealand biogeography. Five out of six Oeconesidae genera are endemic to New Zealand, excepting 
only the monotypic Tascuna from Tasmania (Holzenthal et al. 2007). Family level endemism of Trichoptera is demonstrated by two families in Australia, one in South America and four in Africa, and may thus also be expected in New Zealand. The Chathamiidae are the only caddisfly family with all species present in New Zealand, although also has the unusual dual distinction of containing the only caddisfly species shared with Australia.

\subsection{Marine insects}

The insects represent one of evolution's major success stories. Estimated to represent literally millions of species, no other animal group has radiated to such an extreme degree on land or in fresh water (Erwin 1982, Novotny et al. 2002). Although the oceans cover two thirds of the planet, and not withstanding over 300 million years of evolution, only a handful of insect groups have colonised any marine environment (Cheng 1976, Grimaldi \& Engel 2005). Insects are known to be able to cope with the evolutionary changes in osmotic potential a saline environment presents; inland saline environments even more concentrated than seawater often have thriving insect communities (e.g. Moreno et al. 1997, Herbst 2006, Velasco et al. 2006). Why then insects have generally failed to establish themselves in the sea is an interesting and important question in evolutionary entomology.

Many species of insect are found in marine environments and intertidal areas including many species of adult Coleoptera and Hemiptera, although most remain terrestrial and few are truly aquatic. No species of insect, perhaps with the arguable exception of wingless females of the midges Pontomyia and Clunio spend their entire lives within seawater. Estuarine or brackish areas may or may not be considered to be marine habitats, however here insects can be highly prevalent. For example the larval caddisflies of the genus Limnephilus has been in salt marshes surviving in salinities as high as $30 \%$ (Flint \& Giberson 2005).

Only three insect groups have actively colonised the marine environment with any success, breeding on or within seawater. The sea skater genus Halobates comprises some forty species of 
wingless true bugs of the Gerromorpha (Hemiptera) which have a pleustonic ecology living on the water surface. All species with one freshwater exception live on marine or estuarine waters, and five species have exceptionally colonised even the open ocean (Polhemus 1982, Cheng 1985). In this instance an ecological transition from the coast to the open sea may require minimal adaptation, and the oceanic lifestyle has evolved at least twice in the genus (Andersen et al. 2000). Halobates contrast to other marine insects, as all species have essentially adopted a terrestrial existence on the sea water surface.

The other major lineage can be found amongst Culicomorphid flies. Some mosquito species (Culicidae) breed in isolated saline rock pools (Laird 1988) although by far the greatest radiation is represented by non-biting midges of the Chironomidae. At least fifteen genera of Chironomids have marine representatives which together do not comprise a monophyletic group, having evidently invaded the environment several different times in their evolutionary history (Neuman 1976, Colbo 1996). Although most species are restricted to the intertidal, Chironomids can be abundant; for example larvae of the genus Halocladius are estimated to be among the most abundant of all macroinvertebrates in some intertidal systems (Grabary et al. 2009). Species of Clunio and Pontomyia live in the subtidal, and although being unrelated, both possess a number of analogous similarities including minute size (a few mm), sinking egg masses, extremely short adult lifespan (as low as $1 / 2$ an hour), wing reduction in the adult males, and fully wingless larviform adult females (Neumann 1986, Soong et al. 1999). As is typical with chironomids, almost all of their ontogeny is spent in the fully aquatic larval phase (Cheng \& Collins 1980).

Insects may not be well represented in the seas as a life cycle dominated by a winged adult has no competitive advantage in the marine environment (Cheng 1985). The most specialised of all marine insects, Halobates, Pontomyia and Clunio have totally or partially lost their wings, and likely disperse by means of oceanic diffusion rather than active movement (Ikawa et al. 1998, Anderson et al. 2000). Other features such as largely immobile larvae (at least for the majority of holometabolous insects), internal fertilisation, and evolution of a watertight cuticle likely only further limit marine colonisation for insects as a whole. Other invertebrate taxa, particularily Crustaceans (likely ancestral 
to Insects), already occupy all available niches otherwise filled by insects in land and freshwater. Lacking any competitive potential, it is unlikely insects will re-invade successfully.

\subsection{The natural history and biogeography of New Zealand}

New Zealand represents an ideal region to explore the processes of biogeography. In spite of its small size and isolation, the island group is geologically of continental Gondwanan origin, and is often referred to in scientific literature as being both reminiscent of a continental landmass and a distant oceanic island (Cooper \& Millener 1993, Wallis \& Trewick 2009). This statement applies especially well to the flora and fauna; although a number of plants and animals do appear to reflect vicariant (continental or Gondwanan) origins, more consistently groups appear to have more recent origins from nearby landmasses, more congruent with long distance dispersal. New Zealand is a large landmass, and has an active and complex geology, including processes of mountain building, ice age glaciation and volcanism. Additionally New Zealand itself is comprises a vast and diverse archipelago, and includes a large number of distant oceanic islands, in turn with their own geological and biological histories. The natural history of New Zealand is a vast and highly debated subject, and can only be briefly addressed here.

It is undisputed that New Zealand was once part of the ancient supercontinent Gondwana and connected to what is now Antarctica and Australia, as suggested by an ancient terrestrial fossil record and also clearly demonstrated by an extinct mid ocean ridge in the central Tasman Sea formed by sea floor spreading 85 million years ago and ceasing around 20 million years later (Luyendyk 1995, Sutherland $1999 a$, Trewick et al. 2007). This period saw the rifting of the subcontinent of 'Zealandia' of which modern New Zealand forms only a portion today. Zealandia today is mostly observable under the ocean, forming a mass of underwater rises, ridges and plateaus and taken together with the land surface comprises an area of roughly $3 \frac{1}{12}$ million square kilometres (10 times the size of New Zealand). It is now widely believed that this was once all inactive, flat dry land when still part of 
Gondwana (Campbell \& Hutching 2007, Trewick et al. 2007). Due primarily to erosion and literal tectonic 'stretching' of the crust, most had fallen underwater by the time the Tasman had reached present size roughly 65-60 million years ago. The remainder existed as number of islands, primarily a proto-New Zealand, which continued to sink until the Miocene (23 million years ago), until compressive forces along the plate boundary finally began to uplift new land (Sutherland $1999 \mathrm{~b}$ ). Other areas above sea level, such as New Caledonia, Lord Howe Island and New Zealand's oceanic Islands (such as the Auckland and Chatham Islands) have primarily volcanic origins.

It is currently unclear to what degree the biotas of Zealandia and New Zealand are linked, and some authors have suggested that the two should now be viewed as entirely separate biogeographic entities (Campbell \& Hutching 2007, Trewick et al. 2007, Landis et al. 2008). It is known that during much of the Oligocene (roughly 35-25 Ma) just prior to active tectonism in the Miocene, that most of modern New Zealand was submerged underwater. The event known as the 'Oligocene drowning' has clearly had a considerable effect on the biodiversity of New Zealand, and molecular studies repeatedly display lineages suddenly radiating shortly after this period (Cooper \& Cooper 1995, Trewick \& Morgan-Richards 2005). However it is now becoming increasingly argued that submergence was total, and for several million years there was no emergent land in the area whatsoever. All New Zealand Oligocene sediments are comprised of marine limestone (Campbell \& Hutching 2007, Landis et al. 2008), and the New Zealand crust is unusually thin and less buoyant than typical continental crust, which without ongoing geological activity would quickly sink (Trewick et al. 2007). Furthermore, there are no geologically old features whatsoever in New Zealand, all known terrestrial geological activity and erosion is Miocene or younger (Campbell \& Hutching 2007).

Modern New Zealand clearly does have an unusual and unique biota, and certainly appears to have an old if not Gondwanan origin. Jared Diamond (1990) famously quoted it as being "the nearest approach to life on another planet", reflecting the almost universal scientific opinion of life having been isolated and evolving in the area for tens of millions of years. Among the best known examples include primitive or relicutal taxa representing lineages of probable Mesozoic age, such as the Tuatara (Sphenodontia), Acanthisittid wrens, Leiopelmatid frogs, Ratite birds, the New Zealand parrots 
(Strigopidae), Araucarian conifers (only represented by the Kauri Agathis australis in New Zealand) and dozens of groups of invertebrates, including insects, crustaceans, arachnids, snails, earthworms and the Peripatus (Gibbs 2006). Nevertheless endemicity is almost entirely restricted to the species and genus level (totally so in terrestrial plant species) and there are only a few endemic animal families (Pole 1994, 2000, Macphail 1997, Gibbs 2006). In many more respects New Zealand has biological characteristics more typical of a recently formed oceanic island, and most New Zealand species are likely to have arrived from long distance dispersal, mostly from the nearby landmasses of Australia and New Caledonia.

Contrasting to 'Zealandia', post-Oligocene New Zealand can be defined as period of dynamic geological activity and land-building, and has been the source of much historical biogeographic study. New Zealand has a distinctly defined biogeography, with many regions supporting high or low levels of local endemism, for example species rich areas in the Southern South Island, North West Nelson, and the Northern North Island (Wardle 1963). There are also a number of important biogeographic disjunctions for several species largely congruent with these regions, for example the well known 'beech-gap' found in the Central-Western South Island, where a large number of species are absent (most obviously the forest forming southern beeches of Nothofagus, but also a number of other plants and also animals) in spite of no observable environmental changes (Wardle 1963, Burrows 1965). In the absence of an obvious contemporary cause for these patterns, many are believed to be the result of prior geological or environmental history. Many distributions have been attributed to the movement of the alpine fault since the Miocene, which has had a dramatic effect on the shape and topography of New Zealand. North-South movement of the alpine fault in the South Island has been argued as a recent case of geographic vicariance in New Zealand, as a number of species or related taxa are only present in disjunct regions of North West Nelson and Southern New Zealand, areas that were in close proximity until recently. This pattern is shown in a significant number of species, even in some caddisflies such as the genus Rakiura, and has also been proposed as a cause for the beech gap itself (Heads 1988). However this case of local vicariance has also been discredited by some research and this pattern is more likely to represent more recent local extinctions (Wallis \& Trewick 2001). 
One major geographic event was an extended oceanic submergence of what is now the southern North Island creating the 'Manawatu Straight', an ancient precursor to the Cook Straight, during much of the Pliocene until uplift in the Pleistocene (Lewis et al. 1994, Worthy \& Holdaway 2002) (The modern Cook Strait by contrast is a more recent Pleistocene feature). This period is likely to have resulted in an early phase of allopatric speciation between the modern North and South Islands and has been proposed as a cause for low biological diversity in the Southern North Island (Gibbs 2006). More significantly intensifying plate movement in the Pliocene saw the early formation of the Southern Alps as a distinct mountain range. The formation of the Alps created not just a formidable geographic boundary for plant and animal dispersal, but also greatly diversified the New Zealand region into a distinct series of alpine environments. Since the late Pliocene to Pleistocene New Zealand has also been affected by the onset of a number of glacial cycles or 'ice ages', the last of which, the last glacial maximum (LGM) ended only roughly 20 ka before present (Suggate \& Almond 2005, Denton et al. 2010). Coupled with the presence of a new mountain range, these cycles led to a significant level of glaciation, a massively increased alpine zone, and considerable changes in weather and climate. Particularly during the Pleistocene, ice ages led to massively reduced sea levels, and the landmass of New Zealand has repeatedly increased and decreased in size several times over the last few thousand years. These fluctuating sea levels have more importantly repeatedly opened and shut the Cook and Foveaux Straits, significantly affecting dispersal of both marine and terrestrial species (Suggate et al. 1978, Fleming 1979, McGlone 1988, Naish 2005). The environmental changes in New Zealand since the Pleistocene in this thesis are especially focal to Chapter Two, and will not be discussed further here.

Another very important geological aspect in New Zealand is the presence of volcanism. New Zealand sits along a plate boundary, which north of the alpine fault comprises an active subduction zone, continuing along the Kermadec and Tonga ridges several thousand kilometers northeast into the Pacific. This region has been the source of active volcanism for just as long as mountain building in the South, since the early Miocene $23 \mathrm{Ma}$ (Graham 2008). The central North Island is considerably affected by volcanism, and the Taupo volcano in particular has resulted in some of the largest of all 
worldwide volcanic eruptions in the past several hundred thousand years (Wilson \& Walker 1985, Wilson 1993, McDowall 1996, Alloway et al. 2007). Eruptions from the central plateau have been implicated in the biogeography of some species in the North Island, and are known to have resulted in a number of local extinctions in the past (McDowall 1996, Alloway et al. 2007).

A second significant result of volcanism in the region has been to produce a number of distant oceanic islands, some over 1,000 km from mainland New Zealand. New Zealand is almost completely encircled by distant islands, including Norfolk Island and the Kermadec Islands to the North; the Chatham Islands to the West; and the Antipodes, Campbell, and Auckland Islands to the South. These Islands vary in age and geological origin, although almost all are comprised of volcanic material. The Kermadec Islands represent a continuation of the volcanism directly along the Pacific plate boundary, and are both among the most recent (likely no more than a few thousand years old) and the most active of all New Zealand's volcanic islands. The remaining islands vary in age considerably and have formed typically from ancient basaltic, intra-plate volcanism. Campbell and Auckland Islands are both late Miocene in age (11-7 Ma), Norfolk Pliocene-Miocene (3-2.3 Ma) and the Antipodes late Pleistocene (0.25-0.5 Ma) (Jones \& McDougall 1973, Graham 2008). The Chatham Islands formed mostly from volcanism since the past $6 \mathrm{Ma}$, however do not appear to have emerged until $2 \mathrm{Ma}$, probably due to tectonic uplift (Campbell \& Hutching 2007). All these Islands comprise a number of endemic species of plants and animals, and comprise an important aspect of biogeography in New Zealand; however New Zealand's outer islands are rarely included in contemporary biogeographic studies. Two of New Zealand's oceanic island groups, the Kermadec and Chatham Islands are a focal aspect of Chapter Three of this thesis and are there covered more extensively.

The biological and geological history of New Zealand is long and complex, and here only three areas are to be explored further in any detail in this thesis. The recent Pleistocene glaciations, the age of some of New Zealand's outer Islands, and also the Gondwanan age of New Zealand itself all feature in the Chathamiidae. Thus through use of this small family, this thesis will aim to explore and address the biogeography of New Zealand in a much wider perspective. 


\subsection{Aims and structure of this thesis.}

This thesis aims to focus almost entirely on just a single family of caddisflies, the Chathamiidae, and thoroughly examine it at varying phylogenetic levels. This thesis is divisable into three major areas, each of which is presented in separate chapters as largely independent studies. Each of these three main chapters will also address a theme of a differing biogeographic aspect of the New Zealand region.

Chapter Two will examine a singular species; Philanisus plebeius, which will form the basis of a wide interspecific phylogeography. Samples from around New Zealand and Australia will both be used. This chapter will aim to firstly determine the relationship between the New Zealand and Australian populations, and secondly analyse the phylogeographic patterns found within New Zealand specifically. This chapter being based on a single species will be most sensitive to contemporary or very recent historical events. This will include oceanic currents, current geographic boundaries, possible human shipping and also climate and geographic effects during the Pleistocene, particularily the last glacial maximum (LGM).

Chapter Three will aim to examine the phylogeny of all Chathamiid species, and will attempt to improve the known phylogenetic and taxonomic understanding of the family. As two species here are restricted to Islands (the Kermadec and Chatham Islands), this study will also include use of a strict molecular clock to develop age estimates for the Island taxa, and also serve to establish new evidence for the ages of their respective Island groups. This chapter will also include other caddisfly species from the Chatham Islands for use as a comparison with the endemic Chathamiid, Chathamia brevipennis. Chapter Four will examine the family level phylogeny of the Chathamiidae and related caddisfly species of several related families, both within and outside of New Zealand. Due to the endemicity status of the Chathamiidae, this chapter will aim to address the Gondwanan nature of New Zealand and the possible vicariant age of this family. Finally Chapter Five will briefly discuss the major conclusions and limitations of this thesis, and will also suggest possible future work that may be undertaken. 


\subsection{References:}

Allan CM (1958). Studies on the larva of the marine caddis Philanisus plebeius Walk. MSc Thesis, Otago University.

Alloway BV, Lowe DJ, Barrell DJA, Newham RM, Almon PC, Augustinus PC, Bertler NAN, Carter L, Litchfield NJ, McGlone MS, Shulmeister J, Vandergoes MJ, Williams PW and NZINTIMATE members. Towards a climate event stratigraphy for New Zealand over the past 30 000 ears (NZ-INTIMATE project). Journal of Quaternary Science 22: 9-35

Andersen NM, Cheng L, Damgaard J, Sperling FAH (2000). Mitochondrial DNA sequence variation and phylogeography of oceanic insects (Hemiptera: Gerridae: Halobates spp.) Marine Biology 136: $321-430$

Anderson DT, Fletcher M.J., Lawson-Kerr C. (1976). A marine caddis fly, Philanisus plebeius, ovipositing in a starfish, Patiriella exigua. Search 7: 483-484

Anderson NH (1967). Life Cycle of a Terrestrial Caddisfly, Philocasca demita (Trichoptera: Limnephilidae), in North America. Annals of the Entomological Society of North America 60: 320-323

Anderson DT, Lawson-Kerr C (1977). The Embryonic Development of the Marine Caddis fly, Philanisus plebeius Walker (Trichoptera: Chathamiidae). Biological Bulletin 153: 98-105

Ansorge J (2002). Revision of the "Trichoptera" described by Geinitz and Handlirsch from the Lower Toarcian of Dobbertin (Germany) based on new material. Nova Supplementum Entomologica, Keltern 15: 55-74

Burrows JC (1965). Some discontinuous distributions of plants within New Zealand and their ecological significance II. Disjunctions between Otago-Southland and Nelson Marlborough and related distribution patterns. Tuatara 13: 9-29

Campbell H.J., Hutching G. (2007). In Search of ancient New Zealand. Penguin Books, London.

Colbo MH (1996). Chironomidae from marine coastal environments near St. John's, Newfoundland, Canada. Hydrobiologia 318: 117-122

Collier K (1993). Review of the status, distribution, and conservation of freshwater invertebrates in New Zealand. New Zealand Journal of Marine and Freshwater Research 27: 339-356

Cooper A., Cooper R.A. (1995). The Oligocene bottleneck and New Zealand biota: genetic record of a past environmental crisis. Proceedings of the Royal Society of London, Series B: Biological Sciences 261: 293-302

Cooper RA, Millener PR (1993). The New Zealand Biota; Historical Background and New Research. TRENDS in Ecology and Evolution 8: 429-433

Cowley D.R. (1976). Family characteristics of the pupae of New Zealand Trichoptera. New Zealand Journal of Zoology 3: 99-109

Cheng L (editor) (1976). Marine insects. North-Holland Publishing Co., Amsterdam. 
Cheng, L (1985). Biology of Halobates (Heteroptera: Gerridae). Annual Review of Entomology 30: $111-35$

Diamond J (1997). Guns, germs and steel: the fates of human societies. London, UK, Random House

de Moor FC, Ivanov VD (2008). Global diversity of caddisflies (Trichoptera: Insecta) in freshwater. Hydrobiologia 595: 393-407

Denton GH, RF Anderson RF, Toggweiler JR, Edwards RL, Schaefer JM, Putnam AE (2010). The Last Glacial Termination. Science 328: 1652-1656

Erwin TL (1982). Tropical forests: their richness in Coleoptera and other species. Coleopterist's Bulletin 36: 74-75

Fleming CA (1979). The geological history of New Zealand and its life. Auckland University Press, Auckland.

Flint, OS Jr., Giberson DJ (2005). Salt marsh caddisflies: discovery of the larva and larval habitat of Limnephilus ademus in salt marshes in Prince Edward Island, Canada. Proceedings of the 11th International Symposium on Trichoptera pp. 121-130

Frania H.E., Wiggins G.B (1997). Analysis of morphological and behavioural evidence for the phylogeny of and higher classification of Trichoptera (Insecta). Royal Ontario Museum Life Sciences Contributions 160: 1-67

Garbary DJ, Jamieson MM, Taylor BR (2009). Population ecology of the marine insect Halocladius variabilis (Diptera: Chironomidae) in the rocky intertidal zone of Nova Scotia, Canada. Marine Ecology Progress Series 376: 193-202

Gibbs G (2005). Ghosts of Gondwana: a history of life in New Zealand. Craig Potton Publishing, Nelson.

Graham I (2008).Relicts of a Fiery Past. In: Graham I (editor) A Continent on the Move: New Zealand Geoscience into the $21^{\text {st }}$ Century pp 150-153. Geological Society of New Zealand Miscellaneous Publication 124, 388pp

Grimaldi D, Engel MS (2005). Evolution of the Insects. Cambrige University Press.

Heads M (1988). Biogeographic disjunction along the Alpine fault, New Zealand. Biological Journal of the Linnean Society 63: 161-176

Hudson GV (1904).New Zealand Neuroptera. West, Newman \& Co., London.

Hayashi F, Kamimura Y, Nozaki T (2008). Origin of the Transition from Aquatic to Terrestrial Habits in Nothopsyche Caddisflies (Trichoptera: Limnephilidae) Based on Molecular Phylogeny. Zoological Science 25: 255-260

Henderson I.M., Ward J.B. (2007).Three new species in the endemic New Zealand genus Alloecentrella (Trichoptera) and a re-evaluation of its family placement. Aquatic Insects 29: 79-96 
Herbst DB (1999). Biogeography and physiological adaptations of the brine fly genus Ephydra (Diptera: Ephydridae) in saline waters of the Great Basin. Western North American Naturalist 59: $127-135$

Holzenthal RW, Blahnik RJ, Prather AL, Kjer KM (2007). Order Trichoptera Kirby, 1813 (Insecta), Caddisflies. Zootaxa 1668: 639-698

Ikawa T, Okubo A, Okabe H, Cheng L (1998). Oceanic diffusion and the pelagic insects Halobates spp. (Gerridae: Hemiptera). Marine Biology 131: 195-201

Ivanov VD (2006). Larvae of Caddisflies (Insecta: Trichoptera) from the Mesozoic of Siberia. Paleontological Journal 40: 178-189

Ivanov VD, Sukatsheva ID (2002). Order Trichoptera Kirby, 1813. The caddisflies, pp 199-219. In: Rasinitsyn, AP \& Quicke (editors), History of Insects. Kluwer Academic Publishers; Dordrecht, the Netherlands; $517 \mathrm{pp}$

Johanson K.A., Kjer K. Malm T. (2009). Testing the monophyly of the New Zealand and Australian endemic family Conoesucidae Ross based on combined molecular and morphological data (Insecta: Trichoptera: Sericostomatoidea). Zoologica Scripta 38: 563-573

Johanson K.A., Malm T. (2010). Testing the monophyly of Calocidae (Insecta: Trichoptera) based on multiple molecular data. Molecular Phylogenetics and Evolution 54: 535-541

Jones JG, McDougall J (1973). Geological history of Norfolk and Philip Islands, southwest Pacific Ocean.Journal of the Geological Society of Australia 20: 239-257

Kefford BJ, Dalton A, Palmer CG, Nugegoda D (2004). The salinity tolerance of eggs of selected aquatic macroinvertebrates in south-east Australia and South Africa. Hydrobiologia 517: 179192

Kristensen JP (1975). The phylogeny of hexapod "orders".A critical review of recent accounts. Zeitschrift für Zooligische Systematik und Evolutionsforschung 13: 1-44

Kristensen JP (1991). Phylogeny of extant hexapods. In: Nauman ID (editor), The insects of Australia: A Textbook for Students and Research Workers, Volume 1 ( $2^{\text {nd }}$ edition) pp 125-140. Cornwell University Press, Ithaca, New York, 542pp

Kjer KM, Blahnik RJ, Holzenthal RW (2001). Phylogeny of Trichoptera (Caddisflies): Characterization of Signal and Noise within Multiple Datasets. Systematic Biology 50: 781-816

Kjer KM, Blahnik RJ, Holzenthal RW (2002). Phylogeny of Caddisflies (Insecta, Trichoptera). Zoologica Scripta 31: 83-91

McKnight D.G. (1968). Some Echinoderms from the Chatham Islands.New Zealand Journal of Marine and Freshwater Research 2: 505-526

Landis CA, Campbell HJ, Begg JG, Mildenhall DC, Paterson AM, Trewick SA (2008). The Waipounamu Erosion Surface: questioning the antiquity of the New Zealand land surface and terrestrial fauna and flora. Geological Magazine 145: 173-197

Laird M (1988). The natural history of larval mosquito habitats. Academic Press, London, 555 pp 
Leader JP, Bedford JJ (1979). Oviposition by the marine caddisfly, Philanisus plebeius (Walk.) Search 10: 275-276

Lewis KB, Carter L, Davey FJ (1994). The opening of Cook Strait: interglacial tidal scour and aligning basins at a subduction to transform plate edge. Marine Geology 116: 293-312

Macphail MK (1997). Comment on M. Pole (1994): 'The New Zealand Flora-Entirely Long-Distance Dispersal?' Journal of Biogeography 24: 113-117

McDowall RM (1996). Volcanism and freshwater fish biogeography in the northeastern North Island of New Zealand. 23: 139-148

McGlone (1988). New Zealand. In: Huntley B, Webb T (editors) Vegetation history, pp 557-599. Kluwer Academic Publishers, Dordrecht.

Moreno JL, Millán A, Suárez ML, Vidal-Abarca MR, Velasco J (1997). Aquatic Coleoptera and Heteroptera assemblages in waterbodies from ephemeral coastal streams ("ramblas") of southeastern Spain. Archiv für Hydrobiolgie 141: 93-107

Naish TR (2005). Preface: New Zealand's shallow-marine record of Pliocene-Pleistocene global sealevel and climate change. Journal of the Royal Society of New Zealand 35: 1-8

Neumann D (1976). Adaptations of chironomids to intertidal environments. Annual Review of Entomology 21: 1099-1121

Neumann D (1986). Diel eclosion rhythm of a sublittoral population of the marine insect Pontomyia pacifica. Marine Biology 90: 461-465

Novotny V, Basset Y, Miller SE, Weiblens, Bremer B, Cizek, Drozd P (2002). Low host specificity of herbivorous insects in a tropical forest. Nature 416: 841-844

O'Loughlin PM, Waters JM, Roy MS (2002). Description of a new species of Patiriella from New Zealand, and a review of Patiriella regularis (Echinodermata, Asteroidea) based on morphological and molecular data. Journal of the Royal Society 32: 697-711

Pawson D.L. (1961). Distribution Patterns of New Zealand Echinoderms.Tuatara 9: 9-17

Pole M (1994). The New Zealand Flora-Entirely Long-Distance Dispersal? Journal of Biogeography 21: $625-635$

Pole MS (2001). Can long-distance dispersal be inferred from the New Zealand plant fossil record? Australian Journal of Botany 49: 357-366

Polhemus JT (1982). Marine Hemiptera of the northern territory, including the first fresh-water species of Halobates Eschscholtz (Gerridae, Veliidae, Hermatobatidae and Corixidae). Journal of the Australian Entomological Society 21: 5-11

Ponomarenko AG, Sukatsheva ID, Vasilenko DV (2009). Some Characteristics of the Trichoptera Distribution in the Mesozoic of Eurasia (Insecta: Trichoptera). Paleontological Journal 43: 282-295

Riek EF (1970). Trichoptera. In: CSIRO "Insects of Australia". Melbourne University Press, Melbourne 
Riek EF (1976). The marine caddisfly family Chathamiidae (Trichoptera). Journal of the Australian Entomological Society 15: 405-419

Soong K, Chen GF, Cao JR (1999). Life History Studies of the Flightless Marine Midges Pontomyia spp. (Diptera: Chironomidae). Zoologial Studies 38: 466-473

Suggate RP, Almond PC (2005). The Last Glacial Maximum in western South Island, New Zealand, New Zealand: implications for the global LGM and MIS 2. Quaternary Science Reviews 24: 1923-1940

Suggate RP, Stevens GR, Te Punga MT (1978).The Geology of New Zealand. Government Printer, Wellington, New Zealand.

Sukatsheva ID (1985). Jurassic caddisflies of southern Siberia, pp 1985. In: Rasnitsyn AP (editor), Jurassic Insects of Siberia and Mongolia. Trudy Paleontologischeskogo Instituta Akadmii Nauk, SSSR 211: 192 pp

Sukatsheva ID (1994). Cases of the Early Jurassic caddisflies (Insecta, Trichoptera) from Mongolia. Paleontological Journal 28: 99-113

Sukatsheva ID, Jarzembowski EA (2001). Fossil caddisflies (Insecta: Trichoptera) from the Early Cretaceous of southern England II. Cretaceous Research 22: 685-694

Sutherland R. (1999) $a$. Basement geology and tectonic development of the Greater New Zealand region: an interpretation from regional magnetic data. Tectonophysics 308: 341-362

Sutherland R. (1999) b. Cenozoic bending of New Zealand basement terranes and Alpine fault displacement: a brief review. New Zealand Journal of Geology and Geophysics 42: 295-301

Taylor RB, Cole R.G. (1994). Mobile epifauna on subtidal brown seaweeds in northeastern New Zealand. Marine Ecology Progress Series 115: 271-282

Taylor RB, Steinberg P.D. (2005). Host use by Australasian seaweed mesograzers in relation to feeding preferences of larger grazers, Appendix D. Ecology 86: 2955-2967

Trewick S.A., Morgan-Richards M. (2005). After the deluge: mitochondrial DNA indicates Miocene radiation and Pliocene adaptation of tree and giant weta (Orthoptera: Anostostomatidae). Journal of Biogeography 32: 295-309

Trewick S.A., Paterson A.M., Campbell H.J. (2007). Hello New Zealand. Journal of Biogeography 34: $1-6$

Velasco J, Millán A, Hernández, Gutiérrez C, Abellán, Sánchez D, Ruiz M (2006). Response of biotic communites to saline changes in a Mediterranean hypersaline stream. Saline Systems 2: 2-12

Tillyard RJ (1925). Caddis-flies (Order Trichoptera) from the Chatham Islands. Records of the Canterbury Museum 2: 277-284

Wallis GP, Trewick SA (2001). Finding Fault with Vicariance: A Critique of Heads (1998). 50: 602609

Wallis GP, Trewick SA (2009). New Zealand phylogeography: evolution on a small continent. Molecular Ecology 18: 3548-3580 
Ward JB (1994). The New Zealand Marine Caddisflies (Trichoptera).The Weta.17: 18-20

Ward JB (1995). Nine new species of New Zealand caddis (Trichoptera). New Zealand Journal of Zoology 22: 91-103

Ward JB, Henderson IM (2004). Eleven new species of micro-caddis (Trichoptera: Hydroptilidae) from New Zealand. Records of the Canterbury Museum 18: 9-22

Ward JB, Henderson IM, Patrick BH, Norrie PH (1996). Seasonality, sex ratios and arrival pattern of some New Zealand caddis (Trichoptera) to Light-Traps. Aquatic Insects 18: 157-174

Wardle P (1963). Evolution and distribution of the New Zealand flora, as affected by Quaternary climates. New Zealand Journal of Botany 1: 3-17

Wells A (1992). The first parasitic Trichoptera. Ecological Entomology 17: 299-302

Wells A (2005). Parasitism by hydroptilid caddisflies (Trichoptera) and seven new species of Hydroptilidae from northern Queensland. Australian Journal of Entomology 44: 385-391

Wheeler DA, Whiting M, Wheeler QD, Carpenter JM (2001). The phylogeny of the extant hexapod orders. Cladistics 9: 1-39

Whiting MF (2002). Phylogeny of the holometabolous insect orders: Molecular evidence. Zoologica Scripta 31: 3-15

Wiggins GB (2004). Caddisflies: The Underwater Architects. University of Toronto Press, 266 pp

Willman R (1989). Evolution und phylogenetisches System der Mecoptera (Insecta, Holometabola). Abhandlungen der Senckenbergischen naturforschenden Gesellschaft 83: 277-283

Wilson CJN (1993). Stratigraphy, chronology, styles and dynamics of late Quaternary eruptions from Taupo volcano, New Zealand. Philosophical Transactions of the Royal Society of London, Series A 343: 205-306.

Wilson CJN, Walker GPL (1985).The Taupo eruption, New Zealand. I. General aspects. Philospophical Transactions of the Royal Society of London, Series A 314: 199-228

Winterbourn M.J. \& Anderson N.H. (2008). The life history of Philanisus plebeius Walker (Trichoptera: Chathamiidae), a caddisfly whose eggs were found in a starfish. Ecological Entomology 5: 293-304

Wise K.A.J. (1965).An Annotated list of the Aquatic and Semi-Aquatic Insects of New Zealand.Pacific Insects 7: 191-216

Worthy TH, Holdaway RN (2002). The Lost World of the Moa: Prehistoric Life of New Zealand. Indiana University Press, Bloomington, Indiana.

Young M.W. (1929). Marine Fauna of the Chatham Islands.Transactions of the Royal Society of New Zealand 60 


\section{Chapter Two: Genetic structure of an intertidal insect: phylogeography and cryptic speciation of the marine caddisfly Philanisus plebeius (Trichoptera: Chathamiidae) from New Zealand and Australia.}

\subsection{Introduction}

The Chathamiidae are a small family of five species of caddisfly (Trichoptera) restricted to the coasts of New Zealand and South Western Australia, unusual as all species known or suspected to breed entirely within the marine intertidal and shallow subtidal environments. As a result the family has received a degree of scientific interest, and the most common and widespread species Philanisus plebeius has been the target of ecological and physiological study (Anderson \& Lawson-Ker 1976, Anderson et al. 1976, Winterbourne \& Anderson 1980). However the species still represents a unique opportunity for phylogeographic analysis. The genetic structure of marine insects has been the subject of little research in spite of their evolutionary rarity, and representing a unique link between marine and terrestrial ecosystems.

Very few insects are widely accepted as being marine in nature. A number of species of Chironomid midge (Chironomidae) breed in both the intertidal and subtidal, easily representing the most successful radiation of marine insects. Fifteen genera of chironomids are have marine representatives; most are restricted to brackish or intertidal areas, although tropical species of the flightless genus Pontomyia breed well into the subtidal zone as deep as 30 meters in coral reefs (Hashitomo 1976, Neumann 1976, Bretschko 1981, Colbo 1994). Although there has been work on microsatellite variation in the indertidal genus Clunio (Kaiser \& Heckel 2009), there have been no phylogeographic studies. Flightless Sea skaters of the genus Halobates by adopting a pleustonic lifestyle on the water surface are the only insects to have colonised the open ocean, and have been subject to some phylogenetic and phylogeographic study (Anderson et al. 2000, Damgaard et al. 2000). Chathamiid caddisflies from Australasia arguably represent the only other radiation of fully marine insects, however remain perhaps the least well known. 
New Zealand is an ideal locality in which to explore the processes of biogeography, especially regarding the effects of mountain building, volcanism and climate changes since the Pliocene (Cooper \& Millener 1993, Markgraf et al. 1995, Worthy and Holdaway 2002). Most recently climate and geographical changes due to glacial cycles (roughly 20 in total) during the Pleistocene are well known to have had a considerable environmental effect in New Zealand, with the last such cycle ending 34-18 ka during the last glacial maxiumum (LGM) and modern temperatures appearing around 12 ka (Suggate \& Almond 2005, Denton et al. 2010). During the LGM temperatures dropped up to $5^{\circ} \mathrm{C}$ and led to increases of glacial cover and freshwater outwash, principally in the South Island and also localised areas in the North Island (Fleming 1979, Suggate 1990, Pillans 1991, Brook et al. 2008, Shakun \& Carlson 2010). Lower temperatures greatly increased the alpine zone which also fell to lower altitudes, and forest cover diminished largely to the upper North Island and small localised refugia (McGlone 1988, McGlone et al. 1993, Alloway et al. 2007). Increased ice caps also caused sea levels to lower by around 120-130 m connecting most of New Zealand into a single landmass; thus marine channels such as Cook and Foveaux Straights were largely closed by land bridges dramatically affecting immigration patterns of marine and terrestrial species (e.g. Suggate et al. 1978, Fleming 1979, McGlone 1988, Naish 2005).

The effects of the LGM and past glacial cycles have left a lasting impact still observable in the biogeography and genetic structure of native plants and animals; in terrestrial, freshwater and marine environments. Genetic studies have been conducted on a wide number of freshwater and terrestrial species, finding marked degrees of genetic bottlenecks and postglacial radiations from one or more refugia; including freshwater fish (Wallis et al. 2001, King et al. 2003, Waters et al. 2007b, Waters \& Craw 2008, McDowall 2010), stick insects (Trewick et al. 2005, Buckley et al. 2009, O’Neill et al. 2009), freshwater invertebrates (Neiman \& Lively 2004, Smith \& Smith 2009), bats (Lloyd 2003 a, b), Metrosideros (Gardner et al. 2004), beetles (Leschen et al. 2008, Marske et al. 2009), cicadas (Marshall et al. 2009), skinks (Hare et al. 2008) and frogs (Fouquet et al. 2010). Most of these examples have a South Island focus, North Island studies by contrast often refer to volcanism from the central plateau as an important factor (McDowall 1996, Gardner et al. 2004, Smith et al. 
$2006 a$, b, Shepherd et al. 2007, McDowall 2010). However in spite of extensive research, most studies are focused to those most likely to be sensitive to these environmental changes and are thus are usually biased to inland or habitat-specific species, and do not often include both islands.

The subtidal and intertidal biota of New Zealand has also been the subject of similar study. Observed genetic structuring is generally indicative of contemporary geographical or oceanographic boundaries, most importantly a North-South divide roughly congruent with the North and South Islands (Apte \& Gardner 2002, Sponer \& Roy 2002, Waters \& Roy 2004, Ayers \& Waters 2005, Goldstein et al. 2006, Jones et al. 2008, Shears et al. 2008, Ross et al. 2009). This is usually argued either due to the presence of the Cook Straight since the LGM (Apte \& Gardner 2002), or an older separation from prolonged upwelling off the North-Eastern coast of the South Island acting as a barrier for dispersal (Waters \& Roy 2004, Ayers \& Waters 2005, Goldstein et al. 2006). Evidence for postglacial radiations southwards from northerly refugia have also found been for some marine species, presumably due to intolerance of climate, water current or coastline changes associated with glacial periods (Stevens \& Hogg 2003, Fraser et al. 2009, Hickey et al. 2009).

\subsubsection{The study organism: Philanisus plebeius}

The Chathamiidae are of special interest to New Zealand in particular, as the family comes close to full endemicity status. Four of the five species of the Chathamiidae are endemic to New Zealand and have comparatively restricted distributions; one is restricted to the Kermadec Islands, one to the Chatham Islands, and two in the Northern North Island and nearby Islands. The fifth species Philanisus plebeius has a wider distribution and is found throughout New Zealand, from the Three Kings Islands in the north to Fiordland in the south, and possibly as far south as Northern Stewart Island. This species has also been known to exist in New South Wales since 1904 (Hudson 1904), and has been confirmed to be the same species as that in New Zealand (Riek 1970). Despite its wide range, P. plebeius does have a number of apparent disjunctions in its distribution (see Fig 2.1), and has not been collected from large areas of New Zealand's coastline, including most of the west and 
southern coasts of the South Island; the coasts between Canterbury and Dunedin in the South Island, from East Cape to Hawke's Bay in the North Island, and most of west coast of the North Island (with the exception of records from the Taranaki region). There is one record from Stewart Island, a large gravid female collected in 1980 and labelled as $100 \mathrm{~m}$ altitude far from the coast (Ward 1994). This may be a misidentification or a recording error; there are no other records of $P$. plebeius from the Island. The distribution in Australia is less well known; however appears to extend roughly from Sydney (roughly equal in latitude for the species northernmost distribution in New Zealand at the Three Kings Islands) for about $200 \mathrm{~km}$ of coastline southward. The species does not appear to occur further south in Victoria or Tasmania in spite of these areas being closer to in latitude to most of the species' distribution in New Zealand, and thus likely suitable for colonisation.

P. plebeius breeds exclusively in seawater and most commonly in the rocky intertidal associated with coralline algae, but can be found in variety of habitats such as the shallow subtidal and even in seagrass beds in soft substrate; where the cryptic, herbivorous case-making larvae forage underwater as deep as $2 \mathrm{~m}$ (Riek 1976).This existence in full seawater is the highest salinity (35\%) tolerated by any caddisfly (Kefford et al. 2004, Flint \& Giberson 2005). Pupation also occurs within seawater and the adults emerge late spring early summer, although can be found almost year-round indicating a long adult lifespan (Cowley 1976, Riek 1976, Anderson \& Lawson-Kerr 1977, Ward et al. 1996). The species also demonstrates the extremely unusual behaviour of ovipositing its eggs within the coelom of starfish of the genera Patiriella and Parvalustra, whereupon the first instar larvae leave shortly after hatching (Anderson et al. 1976, Winterbourn \& Anderson 1980). This behaviour is likely more commensal than parasitic, and the starfish is believed to provide a stable environment in which development takes place, and appears more or less unaffected (Anderson \& Lawson-Kerr 1977). It is unclear whether this behaviour is obligate (essential for development) or facultative (opportunistic). How this symbiosis may affect or restrict biogeography or dispersal of $P$. plebeius is unknown, although species of Patiriella and Parvalustra are abundant and widespread in various subtidal and intertidal habitats New Zealand and Australia. 
The trans-Tasman distribution of $P$. plebeius is exceptional; so far all remaining species of caddisfly in New Zealand are fully endemic (Collier 1993). It has been suggested that the Australian population is an accidental human introduction due to shipping (Gibbs 2006), which would make the Chathamiidae as a whole naturally endemic to New Zealand. Human shipping is commonly implicated in the transportation of otherwise poor dispersing marine species, and has been implicated in at least one introduction of a marine chironomid in Western Europe (Brodin \& Andersson 2009, Raunio et al. 2009). By contrast Winterbourn and Anderson (1980) suggested the Australian population is ancestral as the Australian species Parvalustra exigua (formerly Patiriella exigua) are more abundant and found closer to shore than Patiriella regularis from New Zealand, and thus a more likely candidate for the original host species. However since Philanisus plebeius is more widespread in New Zealand and all the remaining species of the Chathamiidae are endemic, it is more parsimonious to consider a New Zealand origin for the species.

Philanisus plebeius has the unique distinction of being an organism found nation-wide with the ecological requirements of a marine species and is thus open to passive transport by marine processes, including currents, rafting of algal wrack or even human shipping. Being fully flighted at adulthood it also behaves as a typical terrestrial insect for a significant portion of its lifespan. Being a member of a largely endemic family, this species is also likely to represent a lineage present in New Zealand for some time, and fully exposed to historical environmental changes. As a result this species has no comparative ecological or biogeographical analogy in New Zealand, and thus presents a unique species for phylogeographic study.

\subsubsection{Aims}

This study will aim to determine the phylogeography of Philanisus plebeius, with two aims. Firstly to establish the genetic relationship between the Australian and New Zealand populations; to determine which region was ancestral, and whether the trans-Tasman distribution is due to natural dispersal or a recent human introduction. Secondly, phylogeographic structure of the population in in 
New Zealand will be investigated. Correlations with historical processes, especially Pleistocene climate and geographic changes will be tested and compared with patterns found of other species representative of the freshwater, marine and terrestrial.

\subsection{Materials and Methods}

\subsubsection{Sample Collection.}

146 Samples of Philanisus plebeius were used in this study from specimens collected specifically for this study from November 2008 to February 2010 from several sites in Australia and both main Islands of New Zealand (see Table 2.1). All New Zealand material was collected by the Author or Dr Ian Henderson (Massey University), whereas Dr Alice Bell (Australian Biological Resources Study, Canberra, Australia) supplied Australian specimens. Adults were primarily collected during dusk and night hours during late summer to early autumn by means of a basic UV light trap. The trap consisted of a $12 \mathrm{v}$ black light powered by a standard $12 \mathrm{v} 7.2 \mathrm{Ah}$ battery, suspended over a water tray with a few drops of detergent. The trap was situated that it would be visible over a wide area of coastline, close to rocky intertidal habitat if possible, and left for typically under an hour. Adults were also occasionally collected by hand during daylight when possible. Larval and pupal material was also collected year round by hand-searching through quantities of coralline algae from the rocky intertidal. Since the larval stages of the Chathamiidae are either unknown or largely indistinguishable morphologically, larval material was collected from areas only inhabited by $P$. plebeius (outside of the Northern North Island).

Samples were placed directly into $70-80 \%$ ethanol in the field and then transferred to $95 \%$ ethanol and refrigerated at $4^{\circ} \mathrm{C}$ for laboratory work. Adults were identified to species in laboratory, with P. plebeius differentiated from the sympatric Philanisus mataua and Chathamia integripennis based on descriptions by Riek (1976) and Ward (1994, 1995). Samples of Chathamia integripennis 
(from Northern New Zealand) and Philanisus fasciatus (Kermadec Islands) were also used as outgroups for phylogenetic analysis (Refer to chapter three of thesis further regarding these species).

\subsubsection{DNA sequencing and alignment.}

DNA was extracted using a standard phenol-chloroform method, using 1-3 whole legs from adults, mature pupae or late-instar larvae. A small fragment of abdominal tissue was used from very small, pupating or damaged larvae only. The remainder of specimen was then left intact and stored in ethanol for future reference.

A 618 base pair fragment of the protein-coding mitochondrial gene Cytochrome oxidase I (COI) was amplified using the primers LCO1490 and HCO2190 (Folmer et al. 1994, see Table. 2.2). Each reaction template was run in a thermocycler for a $95^{\circ} \mathrm{C}$ hot-start for $5 \mathrm{~min} ; 40$ cycles of $30 \mathrm{~s}$ at $95^{\circ} \mathrm{C}, 30 \mathrm{~s}$ at $48-50^{\circ} \mathrm{C}$ and $30 \mathrm{~s}$ at $72^{\circ} \mathrm{C}$; followed by a final extension phase for $10 \mathrm{~min}$ at $72^{\circ} \mathrm{C}$. Products were visualised through gel electrophoresis, purified using $0.5 \mu 1$ ExoSAP-IT DNA purification kit (Global Science) and sequenced using the primer HCO2198 only.

Sequences were imported into Clustal X algorithm in MEGA 4.0 (Kumar et al. 2007, 2008) and aligned using default parameters. COI sequences of $P$. plebeius and $C$. integripennis from published studies (Hogg et al. 2009, Johanson et al. 2009) were imported to facilitate alignment and confirm mitochondrial origin although were not included for analysis.

\subsubsection{Genetic Analyses}

The COI dataset statistics were generated using the MEGA data explorer tool and DnaSP v5 (Librado \& Rozas 2009). TCS 1.21 (Clement et al. 2000) was used to construct a parsimony network, sorting the data into observable haplotypes and to visualise the primary phylogenetic structure and distance. The analysis grouped the sequences into two major haplogroups (" $\mathrm{A}$ ", and "C") with a third 
minor, intermediate haplogroup "B" identified from a single sample. All identified haplotypes were named firstly by their respective grouping and then numbered respective to total abundance (e.g. haplotype "A1") with "1" representing the most numerous. Pairwise distance statistics were performed in DnaSP and used to construct a mismatch distribution chart as to display genetic distances and population structure. Tajima's D (Tajima 1989) and Fu's $F_{S}(\mathrm{Fu} 1997)$ statistics were calculated in DnaSP for the complete dataset and independently for both of the two major haplogroups in order to test for recent demographic expansions.

Analyses of molecular variance (AMOVA) were performed in Arlequin 3.11 to observe genetic relationships at varying geographical hierarchies using data from New Zealand samples of haplogroup A only. Analyses were run using a distance matrix model with 10,000 permutations. Sequences from Australia were omitted from this analysis as they comprised a single unique haplotype, as well as the large geographic distance involved. Also not included were samples from Tauranga and New Plymouth which had less than 6 samples and were considered too geographically isolated from other collection sites to be grouped together. Groupings were based on assumption of a geographic and genetic break South of Kaikora, commonly observed in marine species. Groups from the upper North Island through to Kaikoura were assessed independently (using the geographic groups "Wellington", "Wairarapa", "Auckland" and "Upper South Island"). These groups were then combined (Upper New Zealand) and compared to the further groups "Dunedin" and "Christchurch". In order to improve statistical and geographical robustness, areas in close proximity with small sample sizes were combined into singular 'populations' (distinct from the AMOVA groupings), this included 'Wellington' which combined Pukerua Bay (6), Makara (3), Lyall Bay (1), Pauatahanui (3) and Breaker Bay (12); and 'Auckland' which merged Auckland Harbour (14) with Waiwera (3) (see map in Fig 2.7).

Phylogenetic analyses were also performed on the dataset to further explore the relationship between the three haplogroups using the software packages MrBayes 3.1 (Heulsenbeck \& Ronquist 2001, Ronquist \& Huelsenbeck 2003) and PAUP* 4.0 (Swofford 1999). Model selection was implemented with MODELTEST 3.7 (Posada \& Crandall 1998). The dataset was reduced into single 
sequences for each of the identified haplotypes irrespective of locality to minimise computation time. Philanisus fasciatus and Chathamia integripennis were used as outgroup taxa.

Maximum parsimony (MP, Farris 1970) and Maximum Likelihood (ML, Felsenstein 1981) trees were estimated using PAUP*. Maximum parsimony analysis was performed using a heuristic search model, and bootstrapped using 10,000 replicates. MODELTEST was used to identify the most suitable evolutionary model using the Akiake information criterion (AIC), selecting an HKY + I model. The same model was then implemented for the ML estimates, which was run using 10,000 replicates for bootstrap support with a heuristic search model. In addition a Bayesian analysis was run in MrBayes, once again using the HKY + I model. One cold and three heated Markov chains were run for a total of $50,000,000$ generations sampled every 10,000 to obtain a total of 5,000 trees. The first 1,000 trees (25\%) were discarded as a burn-in phase, with the last 4,000 trees used to estimate the posterior probabilities.

\subsection{Results}

\subsubsection{Sample Collection}

Light trapping only worked during warm, calm nights and some areas yielded no samples (Kaipara Harbour, Muriwai beach, Oamaru, Kaka Point and Curio Bay; see Fig 2.7), or very few (New Plymouth, Mt. Maunganui or Tauranga estuary had only 2 samples each). The remainder of the localities however yielded a larger number of samples, including from rocky, sandy and estuarine beaches. A small number of specimens were also collected from Inland Pukerua Bay, well above sea level and almost a km from the coast. All specimens used for sequencing are listed in Table 2.1. 


\subsubsection{Sequence data}

The dataset comprised 146 sequences of Philanisus plebeius (not including outgroups), with a total 22 recognisable haplotypes (see Tables 2.3 and 2.4). Distance analysis strongly indicated a divergence into three identifiable haplogroups (A, B \& C). Group 'A' comprised 14 haploytpes, 'B' only one, and ' $\mathrm{C}$ ' seven. Haplogroup $\mathrm{C}$ was found in only Napier and Mangakuri beach, and comprised all sequences from these regions. In total the dataset was 618 base pairs long, 23 sites were variable and 14 parsimony informative. Within the two major groupings ' $\mathrm{A}$ ' and ' $\mathrm{C}$ ', 12 and 6 were variable and 2 and 4 were parsimony informative respectively. Base pair frequencies were unequal, averaging $40 \% \mathrm{~T}, 14.8 \% \mathrm{C}, 32.8 \% \mathrm{~A}$ and $12.4 \% \mathrm{G}$ across all sequences.

\subsubsection{Haplotypic and phylogenetic structure.}

Pairwise distances between haplotypes, and also within and between groups are shown in Tables 2.5 and 2.6. The uncorrected pairwise distances were then used for the basis of a mismatch distribution chart (Fig 2.2). The mismatch distribution chart shows a distinct bi-modal peaking, although this only visibly represented groups $\mathrm{A}$ and $\mathrm{C}$, due to the rarity of haplogroup $\mathrm{B}$. The relationships between the haplotypes are also explored in a network analysis in Fig 2.3. The majority of the dataset fell into the 'A' grouping, with group ' $\mathrm{B}$ ' assigned to just one sample, and a secondary major clade ' $\mathrm{C}$ ' restricted to just two closely associated localities near Hawkes Bay (Napier and Mangakuri Beach). Overall, genetic distance within P. plebeius was high (a mean estimate of $1.04 \%$, and a maximum divergence of $1.97 \%$, estimated from the Kimura-2 model), although distances between and within the clades varied. Haplogroup A was dominated by a single haplotype (A1) from which most remaining haplotypes of this group differed from by a single base pair, including those from Australia. Only one (A8) differed by two changes. In contrast the $\mathrm{C}$ group showed a more complex and divergent haplotype network with a relatively bifurcating structure, with a maximum of three base pair changes from the presumed ancestral haplotype (which was not found). Tajima's D and Fu's $F_{S}$ statistics are shown in Table 2.7. Tajima's D was significantly negative for haplogroup A, 
indicating a population expansion; and was non-significant and weakly positive for haplogroup $\mathrm{C}$ (indicating stability). Fu's test by contrast was significantly negative for all cases indicating demographic expansion throughout the species, although this was much more pronounced in haplogroup A than in C.

The bayesian, maximum likelihood (ML) and maximum parsimony (MP) analyses were roughly consistent in all consensus trees and monophyly of Philanisus plebeius was supported (see Figs 2.4-2.6). Group A was monophyletic, weakly suggested to nest with the B haplotype to form a sister grouping, although supported only by the MP and ML analyses. However the C haplogroup was not strongly supported as monophyletic, at best supported by $65 \%$ consensus in the MP analysis, basal to the other two groupings.

\subsubsection{Phylogeographic Structure}

Haplotypic structure showed some degree of geographical association (see Fig 2.7). The 14 identified A group haplotypes of P. plebeius constituted by in large the majority of all samples and localities from this study, including Australia, most of the North Island and all of the South Island. All samples from Australia represented a single haplotype (A3), which although not found in New Zealand differed by a single base pair from the widespread A1 haplotype. The A1 haplotype dominated most of the genetic structure in populations from Auckland south to Kaikoura, and occurred in one sample from Dunedin indicating an almost nationwide distribution. Haplotypic structuring was more distinctive in the lower South Island, sites in Dunedin (Portobello) and Christchurch (Akaroa) were each dominated ( 90\%) by haplotypes mostly only found in these areas; haplotypes 'A2' and 'A4' for Dunedin and Christchurch respectively. Wide genetic connectivity was indicated however, haplotype A2 was found in Kaikoura, Akaroa and Wellington and even Auckland in small proportions, and haplotype A4 also occurred in Kaikoura. Another common haplotype 'A5' was restricted to New Plymouth and Wellington suggesting South-Western North Island connectivity. The remainder of the haplotypes were generally rare and localised with one ('A6') being found once 
in three localities in the North Island (Tauranga, Wellington and Akitio on the Wairarapa coast). The most divergent ' $\mathrm{A}$ ' haplotype (A8) was found only in Tauranga.

Of the other two haplogroups, the $\mathrm{C}$ group was shown to be restricted to just two single localities near Hawke's bay in the North Island (Napier and Mangakuri beach). Of the seven haplotypes found within this group, all showed a degree of geographical association, roughly correlated with the pattern found in the network analysis. Of all haplotypes, only one (C2) was found in both localities, although evidently more common in Napier (50\% of samples as opposed to $12 \%$ in Mangakuri). Haplotypes C3 and C5 were restricted to Napier and closely related to the other major Napier haplotype C2. The remaining haplotypes C1, C4, C6 and C7 were restricted to Mangakuri beach, and similarly appear to form a monophyletic grouping. Haplogroup B was found in just a single sample from Tauranga, sympatric with A group haplotypes.

Analysis of molecular variance (AMOVA) results are shown in Table 2.8. P-values were shown to be largely non-significant, suggesting low genetic structuring to be found within New Zealand populations of 'A' type P. plebeius in New Zealand. In the upper New Zealand grouping, distance within populations accounted for roughly $95 \%$ of the variation found, demonstrating geographic structure to be almost entirely absent. Geographic structure was much more evident when upper New Zealand (Auckland to Kaikoura) was compared to Akaroa and Portobello, with 51\% of the variation found between groupings. Overall, clear geographic structuring was not found in haplogroup A; all $\mathrm{P}$ values were non-significant with the exception of within populations (FCT) in the NorthSouth grouping. The AMOVA tests did however not include Tauranga, Hawke's bay and Australia (due to small sample size, or in the case of Australia, extreme distance), areas with a more pronounced geographic and genetic structure. 


\subsection{Discussion}

\subsubsection{Internal Relationships of Philanisus plebeius}

The most striking result found in this study was the geographic and genetic division of Philanisus plebeius into at least two major identifiable groupings. Whereas samples found throughout Australia and most of New Zealand were genetically similar (haplogroup A), samples from two localities in the central east coast of the North Island (haplogroup C) were found to be hightly genetically divergent from the remainder. Neither of these haplogroups was found to occur sympatrically in any region, indicative of a 'category I' phylogegraphic pattern from Avise et al. (1987). A further distinctive haplotype 'B', intermediate between the two major groupings was found in a single specimen from Tauranga. The genetic distance between the two major haplogroups is at least twice that found within them, approaches that found between P. plebeius and other Chathamiid species (see Chapter Three), and is considerably higher than typical interspecific diversity found within caddisflies (Hogg et al. 2009).

A phylogenetic analysis of the data did not develop clear results, with the exception of supporting the monophyly of haplogroup A. Haplogroup C was inferred to be basal in the MP and ML trees (but this not well supported by the Bayesian tree), with groups A \& B forming a sister relationship. However haplogroup $\mathrm{C}$ was not strongly indicated as being monophyletic in the phylogeny, and was left largely as a polytomy, paraphyletic to the remainder of the species (monophly was only ever weakly supported in the MP tree). At best then the data is probably best represented in an unrooted network as shown in Fig 2.3. The genetic distance within haplogroup $\mathrm{C}$ is demonstrated significantly higher than within the other clades, with two groupings represented, separated by two base pair changes and not joined by an existing intermediate haplotype. Distances between the $\mathrm{C}$ haplogroup and other haplotypes are considerably higher than within however, and it does seem parsimonious to assume a monophyly of all ' $\mathrm{C}$ ' haplotypes. Haplogroup A by contrast appears to reflect almost entirely a single radiation from just one widespread and common haplotype (A1), from which most of the remaining haplotypes differed by a single base pair. One northerly haplotype (A8) 
uniquely differed by two base pair changes and was closer to the other haplogroups, and therefore may be ancestral to A1, via another extant haplotype (either A6 or A13, although A6 seems more probable, being comparatively widespread and occurring sympatrically with A8 and also haplotype 'B').

Also importantly, Haplogroups A \& C had strong geographical associations. Haplogroup C was found only to occur within just two close localities while haplogroup A apparently constituted the large remainder of the entire species' distribution. The limited distribution of haplogroup $\mathrm{C}$ is also surprising when the higher genetic diversity of this grouping is considered. Group C unlike group A shows a deep structure not suggestive of a single radiation, despite its much smaller distribution. This was also supported by Tajima's tests, suggesting a more or less stable demographic structure or history of group $\mathrm{C}$, and a bottleneck or a sudden demographic expansion affecting group $\mathrm{A}$. The evolutionary history of the two major groupings is thus presumed to be widely different.

\subsubsection{Phylogeography of Haplogroup A \& B localities and origin of the Australian population.}

Within all localities, excepting Mangakuri and Napier near Hawke's Bay in the North Island, there was little observable genetic structuring. Diversity within sites was generally not high, and was found to be highest in Wellington (6 haplotypes), the area with the widest collecting (5 closely associated localities) and the largest sample size (25). Samples from Auckland to Kaikoura in the South Island were dominated by one haplotype (A1), while samples from Australia, Akaroa and Portobello were dominated by haplotypes uncommon or absent elsewhere. The observed change between Kaikoura and Dunedin is consistent with a number of marine species in New Zealand, likely due to a zone of upwelling serving as a barrier for oceanic dispersal (Apte \& Gardner 2002, Stevens \& Hogg 2004, Waters \& Roy 2004, Ayers \& Waters 2005, Veale 2007, Ross et al. 2009, Sutherland et al. 2010). However being a marine pattern, this would not affect the migration of adults. The dominant haplotype in Christchurch is also found in Kaikoura, and only 2/14 haplotypes were unique to the South Island (none south of Kaikoura). 
Both New Plymouth samples were of one haplotype (A5) only found elsewhere as a common type in Wellington, suggesting a possible South-Western North Island connection. However sampling there was low there, and is predicted to contain other haplotypes, notably haplotypes A1 and A2 (New Plymouth lies between Auckland and other genetically similar populations which would imply a continual connectivity, unless A group haplotypes are able to bypass populations on the east coast). Tauranga was also shown to be dominated by rare haplotypes constituting the only known ' $\mathrm{B}$ ' haplotype, sympatric with ' $\mathrm{A}$ ' type samples including the only known location of haplotype $\mathrm{A} 8$, and also haplotype A6 (both probably close to the ancestry of haplotype A1 and all other A haplotypes). The small number of samples from New Plymouth and Tauranga (only 2 and 4 respectively) does limit what can be confidently inferred from these observations. The evolutionary diversity exhibited within Tauranga was not repeated elsewhere despite much more thorough sampling, suggesting possible higher diversity in northern areas.

Both Australian localities showed the occurrence of just a single haplotype (A3), with a complete absence of genetic variation indicated. This total of 14 samples from two sites $12 \mathrm{~km}$ apart exhibiting no variation is very different to the situation in New Zealand, where samples over 10 in size from a single location typically comprised at least 2-3 haplotypes. Phylogenetically the Australian haplotype was typical for its haplogroup, having most likely originated from haplotype A1 recently. Thus the Australian population is strongly indicated a recent singular dispersal event from New Zealand. No evidence for contemporary connectivity between New Zealand and Australia was shown. However as the Australian haplotype was not found in New Zealand, a human dispersal within the last 100-200 years appears too recent to allow for sufficient genetic drift to have occurred, and must be rejected at present. However there remains a strong possibility that A3 does exist in an unidentified locality in New Zealand, or has been recently lost due to lineage sorting.

It is clear that the ' $\mathrm{A}$ ' lineage is a radiation event following a very recent genetic bottleneck, strongly supported by Tajima's D and Fu's $F_{S}$ tests. All of haplogroup A with the probable exception of the rare northerly haplotypes A6 and A8 appear to have radiated from the A1 haplotype. Estimating a divergence of this radiation is complicated by the issue that the ancestral haplotype still occurs 
within most localities, although a substitution percentage of $0.16 \%$ can be used ( 1 base pair change). Using a molecular clock such as that of Brower (2.3\% per mya 1994) gives an age estimation of roughly $70 \mathrm{ka}$, whereas another recent molecular clock of 3.59\% for insects (Papadopoulou et al. 2010) gives a younger age of roughly $45 \mathrm{ka}$.

Brower's clock in particular has been known to significantly overestimate the age of divergences however, for example giving a similar date for a radiation in the butterfly species Parnassius mnemosyne more likely to have occured $\sim 19$ ka (Gratton et al. 2008). Estimation of divergences for young dates due to inference from very small numbers of substitutions allows for a very large margin of error. Additionally as the most likely ancestral haplotype is still dominant through most of the distribution, evolution into new haplotypes is still minimal. Thus it seems likely that this divergence is no older than roughly $18-20,000$ years corresponding with the rough age of the end of the last glacial maximum (LGM).

It is probable that haplogroup A and all of P. plebeius as a whole was reduced to northern New Zealand and has thus spread southwards since this time, which may also explain the largely northern dominance of haplotype A1, as well as the northern restriction of haplotypes not directly linked to the presumed southern expansion (particularily haplotypes A6, A8 and also the single B haplotype). This hypothesis is supported as ten of the fourteen ' $A$ ' haplotypes were found only in the North Island, and only two to the South Island (and only to areas north of Kaikoura). This inference is also supported by the complete absence of other haplogroups, and also other Chathamiid species south of the upper North Island. The wide distribution of the other most common haplotype A2 may also represent this expansion rather than current connectivity, and its dominance in Dunedin may simply represent a stochastic founder event rather than having evolved in situ.

Outside of New Zealand there have been numerous studies on freshwater trichoptera demonstrating Pleistocene contractions of populations, followed by re-dispersal during the interglacials from refugia (Wilcock et al. 2001, Baker et al. 2003, Pauls et al. 2006, Murria \& Hughes 2008, Previšić et al. 2009, Lehrian et al. 2009, 2010, Kubow et al. 2010). Postglacial radiations since 
the LGM are known in New Zealand from a number of marine, freshwater and terrestrial examples. More specifically, radiations from northern refugia have been implicated; including fungus beetles (Leschen et al. 2008, Marske et al. 2009), cicadas (Marshall et al. 2009), Stick insects (Trewick et al. 2005, Buckley et al. 2009, Morgan-Richards et al. 2010), bats (Lloyd $2003 a$, b), skinks (Hare et al. 2008), Frogs (Fouquet et al. 2010), the Rātā genus Metrosideros (Gardner et al. 2004) and marine tripplefin fish (Hickey et al. 2009). Postglacial radiation has even been demonstrated in the starfish Patiriella regularis (Waters \& Roy 2004), with which P. plebeius is commensally associated, or even dependent, which adds further support to a glacial retraction of $P$. plebeius.

Philanisus plebeius does appear to be environmentally sensitive and most of the species' apparent disjunctions can probably be ascribed to environmental limitations. Much of the west coast of both islands seems to be uninhabited by the species, likely due to being fully exposed to the west wind drift and thus subjected to high energy wave action and disturbance, and comprises mostly unstable gravel or sand substrates (e.g. Heath 1984, Ewans \& Kibblewhite 1990, Hart \& Bryan 2008, King et al. 2009). There are also large amounts of alpine freshwater outflow in the South Island, potentially effecting marine communities (Bradford 1983). Other disjunctions appear to be temperature dependent. Due to the action of the subtropical convergence belt, cold water at near Stewart Island flows up eastern coast of the South Island to near Banks peninsula, thus water temperatures on the east coast are lower than similar latitudes on the west (Heath 1982, Greig et al. 1986, Carter et al. 1998, Barrows \& Juggins 2005). These areas are characterised only by one single record from Stewart Island, and one confirmed population around Dunedin. Attempted collections on the South coast in this study (Kaka Point and Curio Bay on the Catlins coast) and between Dunedin and Canterbury in the North (Oamaru) found no samples. The Dunedin population may be exceptional as there are no confirmed records outside the Otago harbour. The harbour is likely significantly more sheltered than the surrounding coastline, although surface temperatures there are still known to be low (Greig et al. 1988).

It is thus possible to hypothesise the southernmost limit of $P$. plebeius, likely restricted mostly north of the line characterised by $15^{\circ} \mathrm{C}$ of warmest monthly sea temperature (Barrows \& Juggins 
2005), (which expands to $13 \mathrm{C}^{\circ}$ if Stewart Island and Dunedin are included) (see Fig. 2.7). Warmest water temperature is a likely determinant, probably being important for completing development and stimulating adult emergence (other annual temperatures still display more or less the same regional structure however). Under these assumptions and using data from Barrows \& Juggins (2005), P. plebeius would have been restricted during the LGM to what is now the upper North Island, a contraction significantly more pronounced if modern disjunctions are also assumed. Thus P. plebeius can most likely be considered still existing in the genetic aftermath of a postglacial radiation. The South Western coast of the South Island and most of Northern New Zealand were not sampled, however on the basis of this analysis these are predicted to show low and high genetic diversity respectively.

\subsubsection{Cryptic diversity in P. plebeius: the origin and identity of haplogroup C.}

The status of haplogroup $\mathrm{C}$ is of particular interest due to its significant divergence from haplogroups A and B, combined with a discrete geographic restriction including Hawke's Bay and some of the coastline southwards. Using the molecular clock of Brower (1994), the C group diverged from the other groups anywhere between 265-570 ka before present (using the lower divergence between haplogroups $\mathrm{B}$ and $\mathrm{C}$ ), and itself radiating perhaps as long ago as $350 \mathrm{ka}$. As stated earlier, these dates are likely considerable overestimates but indicate an origin long before the LGM. Phylogeny appears closely correlated with geography, the haplotypes found closely falling within two genetic lineages, each mostly distinct to either Mangakuri or Napier suggesting at least two reproductively isolated populations. Thus migration even within this small region is shown to be low or absent. The populations comprising haplogroup $\mathrm{C}$ are suggested as having reached a relative genetic equilibrium, or at most, affected only by a minor demographic expansion.

Even more significantly, haplotypes were shown to switch from type $\mathrm{C}$ abruptly to type A between samples from Mangakuri and Whangaehu beaches, a transitional break of just $54 \mathrm{~km}$. It is unknown whether $P$. plebeius occurs between the areas; however as coastal morphology and habitat is 
more or less continuous thus it appears probable. A possible genetic turnover or population gap may occur at the outflow of the Porangahau River providing estuarine habitats and sandy subsrate unsuitable for breeding. Adult samples were collected in much larger estuaries in this study alone (Pauatahanui inlet near Wellington and Tauranga estuary), which does suggest a tolerance of the habitat at least for adults.

Alternatively, a genetic barrier may relate to offshore currents. The circular Wairarapa eddy occurs near offshore, and the Southerly flowing East Cape current and the northerly flowing Wairarapa coastal current both converge near Hawke's bay (Heath 1982, Carter et al. 1998). Both or all these may represent a likely considerable barrier for marine coastal species, deflecting immigrants and preventing successful emmigration. Largely basal haplotypes from the same region have been observed in a reproductive brooding fish species, the seahorse Hippocampus abdominalis (Nickel 2009). Limpet samples from near Napier were shown to represent an allopatric population of a cryptic species, although this taxon had an apparent disjunct distribution being sympatric with a related species in two sites in northern New Zealand (Nakano \& Spencer 2007). As similar to the genetic disjunction in the south Island this once again raises the question of larval over adult dispersal in $P$. plebeius.

The Northern boundary was not identified in this study but $P$. plebeius are uncollected from the coastline north of Napier through to East Cape. The coastline of this region appears to have appropriate habitat, including rocky shores. Therefore this 'disjunction' may reflect sampling bias, and the species may be fully present. However absence in this region is congruent with volcanism from the central plateau. Taupo volcano is among the most active rhyolitic volcanoes in existence; erupting nearly 30 times in the last 30,000 years with the last such event in $186 \mathrm{AD}$, and the largest (the Oruanui/Kawakawa eruption $\sim 26.5 \mathrm{ka}$ ) producing $1200 \mathrm{~km}^{3}$ of material (Wilson \& Walker 1985, Wilson 1993, McDowall 1996, Alloway et al. 2007). The outflows from each eruption tend to have spread eastwards and centralised tephra layers from the Oruanui/Kawakawa eruption $2 \mathrm{~m}$ in depth have been found as far eastwards as Hawke's bay (Wilson 2001, Alloway et al. 2007, Lowe et al. 2008). Volcanism, including the recent $186 \mathrm{AD}$ eruption has been well evidenced in the current 
biodiversity of the eastern North Island, especially the freshwater fauna (McDowall 1996). Eastward ashflows from the $186 \mathrm{AD}$ eruption in particular fit with the apparent disjunction of P. plebeius in the eastern North Island, although the effects of volcanism not been demonstrated as of yet in any marine species in this region, and the presence or absence of $P$. plebieus in this still region requires confirmation.

During the last glacial maximum and previous glaciations, the area including Hawkes Bay and immediately southwards may have represented the southernmost distribution of P. plebeius (see Fig 2.7). If the East Cape region is assumed to be uninhabited by P. plebeius, due to volcanism or otherwise then this area could have represented a fully isolated population, at least during glacial cycles. Repeated glacial cycles over time combined with genetic drift may have eventually allowed for a high degree of molecular divergence to develop. However if volcanism is implicated as above, then events such as the Oruanui/Kawakawa eruption which occurred during the LGM would have obliterated populations much further south than the 186 AD eruption, weakening this hypothesis somewhat.

A hypothetical separation of the ancestral populations of each of the two main haplogroups may explain current genetic differentiation, although why gene flow has apparently never resumed, or apparent lack of any dispersal whatsoever, is unclear. Geographic relationship between the A and C groupings appears peripatric rather than allopatric, and contact between adults seems highly probable. Caddisflies of the genus Gumaga in California have been found to represent an apparent cryptic species complex, maintaining reproductive isolation from one another in spite of close proximity (Jackson \& Resh 1998), suggesting this pattern may be widespread. If genetic difference is sufficiently high then species are likely to exhibit assortative mating and thus not interbreed. Sex pheromones are confirmed to be important in mate recognition in a wide diversity of species in trichoptera (e.g. Wood \& Resh 1984, Jackson \& Resh 1991, Larsson \& Hansson 1998) Although individuals of each genetic group may appear physically indistinguishable, sex pheromones may differ substantially enough to prevent mate recognition; a trait known to occur otherwise physically 
similar cryptic insect species (Foster et al. 1991, Maingon et al. 2003, Watts et al. 2005, Cáceres et al. 2009).

The high genetic distance, as well as possible assortative mating and geographical conservatism suggest that haplogroup C may represent an unidentified cryptic species. Morphological differences were not clearly observed with the possible exception of decreased wing length (Ian Henderson, personal communication). Confirmation of this however requires a thorough analysis of wing length and shape, a morphological attribute likely to show a high degree of phenotypic plasticity; likely correlated to sex (females are typically larger) and developmental history. More thorough sampling to identify the full distribution of the ' $\mathrm{C}$ ' haplogroup, or identifiable physical features; need to be identified before separate species status is proposed. For the time being at least, it seems practical to retain $P$. plebeius as a singular species, although the possibility of superspecies or species complex is indicated by this study.

\subsubsection{Inferred molecular ecology of Philanisus plebeius and conclusions.}

From this study it seemed to be probable, at least in some areas, contemporary gene flow and overall dispersal and immigration of Philanisus plebeius was fairly low, although this pattern was obscured by low genetic diversity through most of the populations. Adult P. plebeius are rare inland; in this study occasional samples roughly $1 \mathrm{~km}$ from the coast were collected, and maximum distances up to $3 \mathrm{~km}$ away have been shown in some records. As is generally typical of caddisflies, adults tend not to travel far from suitable breeding habitat and dispersal tends to be along water bodies rather than between them (e.g. Kovats et al. 1996, Collier \& Smith 1998, Griffith et al. 1998, Peterson et al. 1999, 2004). As a result, $P$. plebeius likely disperses almost entirely along the coast, requiring flight distances over hundreds of kilometres to link some isolated populations. This seems difficult to accept regarding populations in or around the distribution of the ' $\mathrm{C}$ ' haplotype grouping, where haplotypes are not co-occurring in distances within tens of kilometres, despite the presumed thousands of years for gene flow to have occurred. 
Dispersal capability of adult caddisflies is known to be highly variable, depending on the species concerned. Contemporary molecular studies on caddisflies often do demonstrate occasional gene flow over widely isolated populations such as between the Canary Islands, demonstrating occasional or even regular dispersal over 50-100 km of open ocean (Kelly et al. 2001, 2002, Schultheis \& Hughes 2005, Wilcock et al. 2007). However smaller scale dispersal, generally under 20 $\mathrm{km}$ has also been indicated and gene flow is suggested more to occur over several generations in other species (Wilcock et al. 2003, 2007). In New Zealand, phylogeographic studies on the caddisfly Orthopsyche fimbriata have demonstrated little or no contemporary gene flow between populations in river catchments over $100 \mathrm{~km}$ apart, although more closely associated streams do share haplotypes (Smith \& Collier 2001, Smith et al. 2006 b, Smith \& Smith 2009).

Of all marine insects, the Chathamiidae appear to be perhaps the least specialised. Flight is assumed to be a major factor in the success of insects on land allowing dispersal between discontinuous habitats, but likely to have no competitive advantage in the marine environment (Cheng 1985). Concerning the most specialised marine insects; all species of Halobates are completely wingless, and only the short-lived males of the marine midge genera Clunio and Pontomyia still possess wings, used for gliding short distances or as literal 'oars' for pleustonic movement during reproductive mass-emergences (Neuman 1976, Cheng \& Collins 1980, Cheng 1985). As active movement of caddisly larvae is presumed to be low, distribution in the intertidal is likely restricted to where the larvae emerged from their starfish hosts. It seems probable as with some marine chironomids, the distribution of $P$. plebeius in the intertidal is likely 'clumped' or localised (Garbary et al. 2005). As also suggested by close relationships within populations, recruitment of larvae is probably almost entirely from the source adult population.

However some haplotypes were found distributed widely throughout New Zealand, in spite of some of the massive distances between populations, and some genetic breaks do appear to roughly correlate with marine patterns. This suggests a significant amount of migration may in occur in the passive movement of marine larvae instead of active flight by adults. 'Drift' of dislodged caddisfly larvae is common in stream environments, although similar transport by currents in the sea would 
almost invariably be fatal for an intertidal species. Nevertheless passive dispersal seems to be a significant source of dispersal for other marine insect species; for example Schärer and Epler (2007) demonstrated the unusual transport mechanism of Pontomyia on the shells of hawksbill turtles as part of the epibiota. Adults of Pontomyia and are largely flightless (completely in females) and have lifespans restricted to a few hours (Neuman 1986, Soong et al. 1999), and are thus likely completely dependent on dispersal of larvae and egg masses for long distance dispersal. Likewise dispersal of Halobates is believed to be largely passive, and mostly relates to oceanic 'diffusion' by water motion than active movement of individuals (Ikawa et al. 1998, Anderson et al. 2000).

P. plebeius are associated with a large number of algal types, including seagrass in soft sediment (Riek 1976, Taylor \& Cole 1994, Taylor \& Steinberg 2005). Dispersal or rafting of algal rafts and the associated invertebrate communities is becoming increasingly appreciated as an important vector of rapid dispersal for marine organisms over hundreds of kilometers (Waters 2008, Fraser et al. 2009, 2010). Small numbers of P. plebeius, especially if in a dormant pupal phase (which also then would directly lead to adulthood, not requiring landfall on suitable habitat), could thus easily thus be transported by rafting. Additionally host starfish containing eggs or larvae may provide a robust refuge within which such rafting may occur (and also would themselves actively seek appropriate habitats). Human shipping may also provide a recent vector for dispersal, for both larvae and adults, which may explain some of the structure observed as it would allow for a bypass of certain geographic areas. Although not definitively demonstrated in $P$. plebieus, human shipping has been implicated in the dispersal of marine chironomids in Europe (Brodin \& Andersson 2009, Raunio et al. 2009).

Overall it is proposed here that $P$. plebeius is a poor active disperser, and phylogeographic structure can be plausibly explained by marine processes. It is assumed that climatic and environmental changes had a profound impact on the species, and re-dispersal to distant localities has since the LGM has been primarily due to passive dispersal of larvae rather than active flight of adults, although stochastic long-distance dispersal of adults also seems likely. Possible important factors implicating the results found in this study do have to be considered. An important limitation was the 
use of a single mitochondrial gene. Mitochondria (with very rare exceptions) are maternally inherited, and since no nuclear genes were used paternal inheritance was completely ignored. Male P. plebeius are smaller and presumably more active and prone to migration, constituting the majority of adult samples in most localities in this study and also in Winterbourne \& Anderson (1980). Additionally some geographically significant areas, in particular Northern New Zealand and the South-Western South Island were especially under sampled. More sampling may reveal new localities of haplogroups $\mathrm{B}$ and $\mathrm{C}$, and may yield more cryptic diversity not shown here. Thus the conclusions drawn here may be confidently confirmed or disproven with some further research. Nevertheless the prospect of $P$. plebieus as a new model organism for phylogeographic exploration in New Zealand is well demonstrated in this study. 


\section{$2.5 \quad$ Figures}

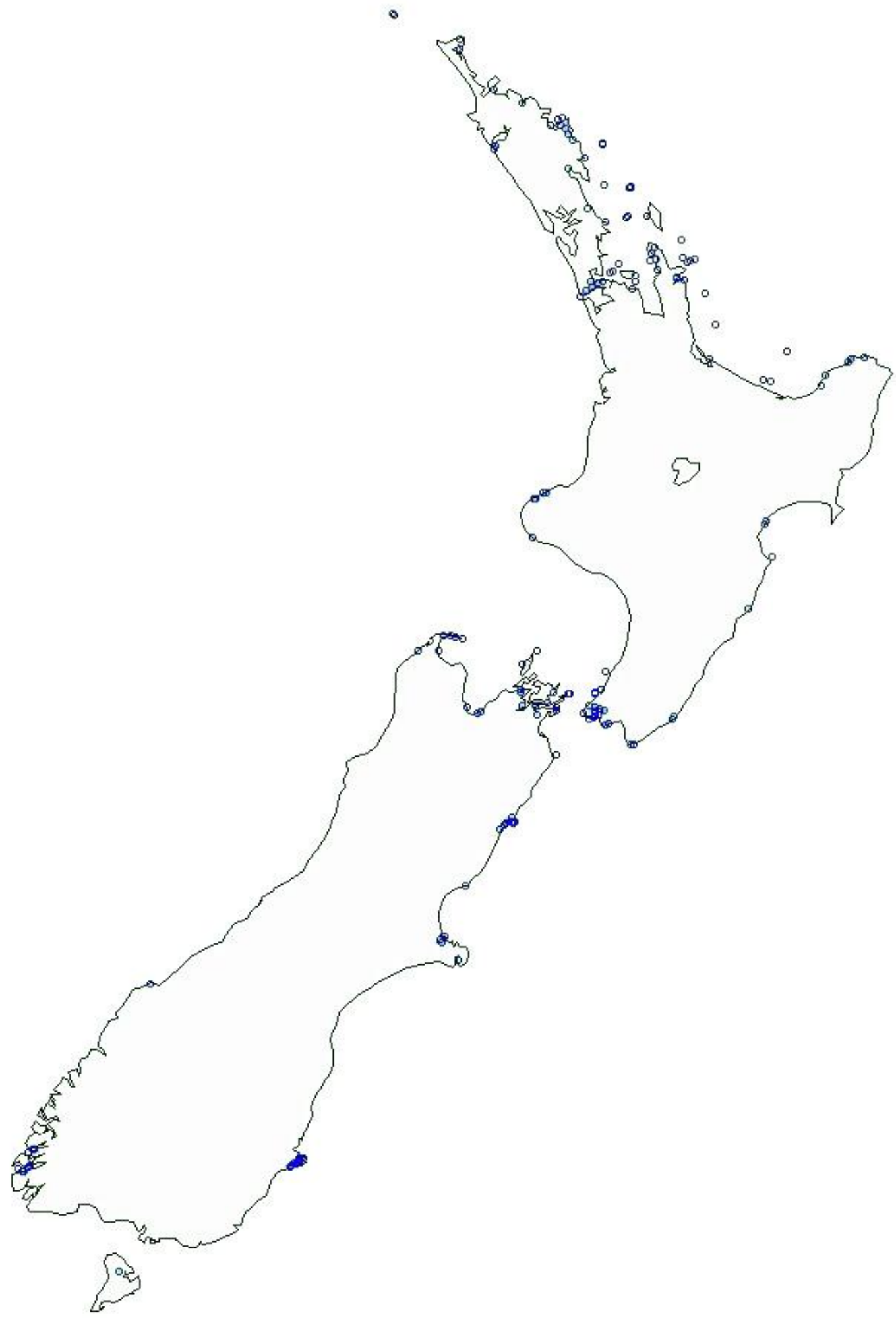

FIG 2.1) Collection records of Philanisus plebeius taken direct from the New Zealand trichoptera collection database (http://nzcaddis.massey.ac.nz/). Note apparent disjunctions on the eastern North Island, the South Eastern South Island, and most of the West Coast of both Islands. The collection from Stewart Island is anomalous and possibly an error (unconfirmed). This does not include the Australian distribution of the species (New South Wales only). 
TABLE 2.1) List of all samples used for sequencing in this study, and collection details. Brackets in locality designate "greater locality" used due to close association of sites and/or low sample numbers. Note repetitions of localities due to multiple collections.

\begin{tabular}{|c|c|c|c|c|c|c|c|}
\hline Species & Specimen Code & Number & Ontogeny & Collector & Locality & Coordinates & Collection Date \\
\hline Philanisus plebeius & K3 & 11 & Adult & Ian Henderson & Akaroa & $43^{\circ} 48^{\prime} 06 \mathrm{~S}, 172^{\circ} 58^{\prime} 06 \mathrm{E}$ & $1 / 02 / 2009$ \\
\hline Philanisus plebeius & L4 & 12 & Adult & Ian Henderson & AkitioBeach & $40^{\circ} 36^{\prime} 21 \mathrm{~S}, 176^{\circ} 25^{\prime} 14 \mathrm{E}$ & $21 / 02 / 2010$ \\
\hline Philanisus plebeius & B6, B9 & 14 & Adult & Alex Boast & Auckland Harbour (Auckland) & $36^{\circ} 50^{\prime} 30 \mathrm{~S}, 174^{\circ} 51^{\prime} 48 \mathrm{E}$ & $6 / 03 / 2009$ \\
\hline Philanisus plebeius & K10 & 6 & Adult & Alice Wells & Bawley Point (New South Wales) & $35^{\circ} 30^{\prime} 50 \mathrm{~S}, 150^{\circ} 24^{\prime} 03 \mathrm{E}$ & $21 / 11 / 2008$ \\
\hline Philanisus plebeius & L1 & 1 & Larva & Alice Wells & Bawley Point (New South Wales) & $35^{\circ} 30^{\prime} 50 \mathrm{~S}, 150^{\circ} 24^{\prime} 03 \mathrm{E}$ & $21 / 11 / 2008$ \\
\hline Philanisus plebeius & A5, A6 & 12 & Adult & Alex Boast & Breaker Bay (Wellington) & $41^{\circ} 20^{\prime} 38 \mathrm{~S}, 174^{\circ} 49^{\prime} 19 \mathrm{E}$ & $12 / 01 / 2009$ \\
\hline Philanisus plebeius & $\mathrm{K} 1$ & 10 & Adult & Ian Henderson & Kaikoura & $42^{\circ} 24^{\prime} 50 \mathrm{~S}, 173^{\circ} 41^{\prime} 07 \mathrm{E}$ & $31 / 01 / 2009$ \\
\hline Philanisus plebeius & $\mathrm{K} 2$ & 1 & Adult & Ian Henderson & Kaikoura & $42^{\circ} 24^{\prime} 50 \mathrm{~S}, 173^{\circ} 41^{\prime} 07 \mathrm{E}$ & $31 / 01 / 2009$ \\
\hline Philanisus plebeius & A4 & 1 & Adult & Alex Boast & Lyall Bay (Wellington) & $41^{\circ} 20^{\prime} 43 \mathrm{~S}, 174^{\circ} 47^{\prime} 35 \mathrm{E}$ & $8 / 01 / 2009$ \\
\hline Philanisus plebeius & $\mathrm{C} 1$ & 3 & Larvae & Alex Boast & Makara (Wellington) & $41^{\circ} 12^{\prime} 55 \mathrm{~S}, 174^{\circ} 42^{\prime} 15 \mathrm{E}$ & $21 / 07 / 2009$ \\
\hline Philanisus plebeius & B4, B5 & 4 & Adult & Alex Boast & Mangakuri Beach & $39^{\circ} 57^{\prime} 59 \mathrm{~S}, 176^{\circ} 55^{\prime} 14 \mathrm{E}$ & $28 / 02 / 2009$ \\
\hline Philanisus plebeius & B2, B3 & 7 & Adult & Alex Boast & Mangakuri Beach & $39^{\circ} 57^{\prime} 59 \mathrm{~S}, 176^{\circ} 55^{\prime} 14 \mathrm{E}$ & $27 / 02 / 2009$ \\
\hline Philanisus plebeius & $\mathrm{C} 2$ & 6 & Adult & Alex Boast & Mangakuri Beach & $39^{\circ} 57^{\prime} 59 \mathrm{~S}, 176^{\circ} 55^{\prime} 14 \mathrm{E}$ & $21 / 07 / 2009$ \\
\hline Philanisus plebeius & $\mathrm{L} 2$ & 6 & Adult & Ian Henderson & Te Rua Bay, Marlborough Sounds & $41^{\circ} 14^{\prime} 25 \mathrm{~S}, 174^{\circ} 16^{\prime} 14 \mathrm{E}$ & $30 / 12 / 2008$ \\
\hline Philanisus plebeius & B1 & 2 & Adult & Alex Boast & Mount Maunganui (Tauranga) & $37^{\circ} 37^{\prime} 30 \mathrm{~S}, 174^{\circ} 10^{\prime} 29 \mathrm{E}$ & $17 / 02 / 2009$ \\
\hline Philanisus plebeius & A7 & 6 & Adult & Alex Boast & Napier & $39^{\circ} 28^{\prime} 39 \mathrm{~S}, 176^{\circ} 54^{\prime} 31 \mathrm{E}$ & $15 / 01 / 2009$ \\
\hline Philanisus plebeius & K6 & 2 & Adult & Ian Henderson & New Plymouth & $39^{\circ} 03^{\prime} 21 \mathrm{~S}, 174^{\circ} 01^{\prime} 47 \mathrm{E}$ & $25 / 11 / 2008$ \\
\hline Philanisus plebeius & A9 & 3 & Adult & Alex Boast & Pauatahanui Inlet (Wellington) & $41^{\circ} 05^{\prime} 50 \mathrm{~S}, 174^{\circ} 54^{\prime} 33 \mathrm{E}$ & $21 / 01 / 2009$ \\
\hline Philanisus plebeius & $\mathrm{K} 7, \mathrm{~K} 8$ & 7 & Larva / Pupae & Alice Wells & Pebbly Beach (New South Wales) & $35^{\circ} 36^{\prime} 33 \mathrm{~S}, 150^{\circ} 20^{\prime} 09 \mathrm{E}$ & $22 / 11 / 2008$ \\
\hline Philanisus plebeius & $\mathrm{K} 4$ & 9 & Adult & Ian Henderson & Portobello & $45^{\circ} 50^{\prime} 23 \mathrm{~S}, 170^{\circ} 39^{\prime} 02 \mathrm{E}$ & $3 / 02 / 2009$ \\
\hline Philanisus plebeius & K5 & 1 & Adult & Ian Henderson & Portobello & $45^{\circ} 50^{\prime} 23 \mathrm{~S}, 170^{\circ} 39^{\prime} 02 \mathrm{E}$ & $4 / 02 / 2009$ \\
\hline Philanisus plebeius & A3 & 1 & Adult & Alex Boast & Pukerua Bay (Wellington) & $41^{\circ} 01^{\prime} 39 \mathrm{~S}, 174^{\circ} 53^{\prime} 15 \mathrm{E}$ & $26 / 12 / 2008$ \\
\hline Philanisus plebeius & A8 & 4 & Adult & Alex Boast & Pukerua Bay (Wellington) & $41^{\circ} 01^{\prime} 39 \mathrm{~S}, 174^{\circ} 53^{\prime} 15 \mathrm{E}$ & $21 / 01 / 2009$ \\
\hline Philanisus plebeius & B10 & 1 & Adult & Alex Boast & Pukerua Bay (Wellington) & $41^{\circ} 02^{\prime} 18 \mathrm{~S}, 174^{\circ} 53^{\prime} 22 \mathrm{E}$ & $15 / 04 / 2009$ \\
\hline Philanisus plebeius & A10 & 2 & Adult & Alex Boast & Tauranga estuary (Tauranga) & $37^{\circ} 42^{\prime} 29 \mathrm{~S}, 174^{\circ} 53^{\prime} 15 \mathrm{E}$ & $16 / 02 / 2009$ \\
\hline
\end{tabular}


TABLE 2.1) Continued.

\begin{tabular}{|c|c|c|c|c|c|c|c|}
\hline Species & Specimen Code & Number & Ontogeny & Collector & Locality & Coordinates & Collection Date \\
\hline Philanisus plebeius & B7, B8 & 3 & Adult & Alex Boast & Waiwera (Auckland) & $36^{\circ} 32^{\prime} 56 \mathrm{~S}, 174^{\circ} 42^{\prime} 32 \mathrm{E}$ & $8 / 03 / 2009$ \\
\hline Philanisus plebeius & L3 & 11 & Adult & Ian Henderson & Whangaehu Beach & $40^{\circ} 23^{\prime} 54 \mathrm{~S}, 176^{\circ} 38^{\prime} 05 \mathrm{E}$ & $11 / 12 / 2009$ \\
\hline Philanisus fasciatus & PF101 & 1 & Adult & Karen Baird & Raoul Island & $29^{\circ} 14^{\prime} 56 \mathrm{~S}, 177^{\circ} 55^{\prime} 14 \mathrm{E}$ & $20 / 10 / 2009$ \\
\hline Chathamia integripennis & CI1 & 1 & Adult & Alex Boast & Waiwera & $36^{\circ} 32^{\prime} 56 \mathrm{~S}, 174^{\circ} 42^{\prime} 32 \mathrm{E}$ & $8 / 03 / 2009$ \\
\hline
\end{tabular}

TABLE 2.2) Primers used for amplification and sequencing.

\begin{tabular}{llll}
\hline Gene & Primer Name & Primer sequences $\left(\mathbf{5}^{\prime} \mathbf{- 3}\right.$ ') & Reference \\
\hline COI & HCO2198 & TAAACTTCAGGGTGACCAAAAAATCA & Folmeret al. 1994 \\
COI & LCO1490 & GGTCAACAAATCATAAAGATATTGG & Folmeret al. 1994
\end{tabular}


TABLE 2.3) All haplotypes found in this study and frequency in each locality. Specific locality is here used.

\begin{tabular}{|c|c|c|c|c|c|c|c|c|c|c|c|c|c|c|c|c|c|c|c|c|c|c|c|}
\hline Haplotype & $\mathrm{A} 1$ & $\mathrm{~A} 2$ & $\mathrm{~A} 3$ & $\mathrm{~A} 4$ & A5 & A6 & A7 & $\mathrm{A} 8$ & A9 & $\mathrm{A} 10$ & A11 & $\mathrm{A} 12$ & A13 & A14 & $\mathrm{B}$ & $\mathrm{C} 1$ & $\mathrm{C} 2$ & $\mathrm{C} 3$ & $\mathrm{C} 4$ & $\mathrm{C} 5$ & C6 & $\mathrm{C} 7$ & $\mathrm{~N}$ \\
\hline Akaroa & 0 & 1 & 0 & 10 & 0 & 0 & 0 & 0 & 0 & 0 & 0 & 0 & 0 & 0 & 0 & 0 & 0 & 0 & 0 & 0 & 0 & 0 & 11 \\
\hline Akitio & 9 & 0 & 0 & 0 & 0 & 1 & 0 & 0 & 1 & 0 & 0 & 0 & 0 & 1 & 0 & 0 & 0 & 0 & 0 & 0 & 0 & 0 & 12 \\
\hline Auckland & 12 & 0 & 0 & 0 & 0 & 0 & 2 & 0 & 0 & 0 & 0 & 0 & 0 & 0 & 0 & 0 & 0 & 0 & 0 & 0 & 0 & 0 & 14 \\
\hline Bawley Point & 0 & 0 & 7 & 0 & 0 & 0 & 0 & 0 & 0 & 0 & 0 & 0 & 0 & 0 & 0 & 0 & 0 & 0 & 0 & 0 & 0 & 0 & 7 \\
\hline Kaikora & 9 & 1 & 0 & 1 & 0 & 0 & 0 & 0 & 0 & 0 & 0 & 0 & 0 & 0 & 0 & 0 & 0 & 0 & 0 & 0 & 0 & 0 & 11 \\
\hline Lyall Bay & 1 & 0 & 0 & 0 & 0 & 0 & 0 & 0 & 0 & 0 & 0 & 0 & 0 & 0 & 0 & 0 & 0 & 0 & 0 & 0 & 0 & 0 & 1 \\
\hline Makara & 1 & 0 & 0 & 0 & 2 & 0 & 0 & 0 & 0 & 0 & 0 & 0 & 0 & 0 & 0 & 0 & 0 & 0 & 0 & 0 & 0 & 0 & 3 \\
\hline Mangakuri & 0 & 0 & 0 & 0 & 0 & 0 & 0 & 0 & 0 & 0 & 0 & 0 & 0 & 0 & 0 & 11 & 2 & 0 & 2 & 0 & 1 & 1 & 17 \\
\hline Marlborough Sounds & 5 & 0 & 0 & 0 & 0 & 0 & 0 & 0 & 0 & 1 & 0 & 0 & 0 & 0 & 0 & 0 & 0 & 0 & 0 & 0 & 0 & 0 & 6 \\
\hline Moa Point & 7 & 1 & 0 & 0 & 1 & 1 & 0 & 0 & 0 & 0 & 1 & 1 & 0 & 0 & 0 & 0 & 0 & 0 & 0 & 0 & 0 & 0 & 12 \\
\hline Mount Maunganui & 0 & 0 & 0 & 0 & 0 & 0 & 0 & 2 & 0 & 0 & 0 & 0 & 0 & 0 & 0 & 0 & 0 & 0 & 0 & 0 & 0 & 0 & 2 \\
\hline Napier & 0 & 0 & 0 & 0 & 0 & 0 & 0 & 0 & 0 & 0 & 0 & 0 & 0 & 0 & 0 & 0 & 3 & 2 & 0 & 1 & 0 & 0 & 6 \\
\hline New Plymouth & 0 & 0 & 0 & 0 & 2 & 0 & 0 & 0 & 0 & 0 & 0 & 0 & 0 & 0 & 0 & 0 & 0 & 0 & 0 & 0 & 0 & 0 & 2 \\
\hline Pauatahanui & 1 & 2 & 0 & 0 & 0 & 0 & 0 & 0 & 0 & 0 & 0 & 0 & 0 & 0 & 0 & 0 & 0 & 0 & 0 & 0 & 0 & 0 & 3 \\
\hline Pebbly Beach & 0 & 0 & 7 & 0 & 0 & 0 & 0 & 0 & 0 & 0 & 0 & 0 & 0 & 0 & 0 & 0 & 0 & 0 & 0 & 0 & 0 & 0 & 7 \\
\hline Portobello & 1 & 9 & 0 & 0 & 0 & 0 & 0 & 0 & 0 & 0 & 0 & 0 & 0 & 0 & 0 & 0 & 0 & 0 & 0 & 0 & 0 & 0 & 10 \\
\hline Pukerua Bay & 3 & 0 & 0 & 0 & 3 & 0 & 0 & 0 & 0 & 0 & 0 & 0 & 0 & 0 & 0 & 0 & 0 & 0 & 0 & 0 & 0 & 0 & 6 \\
\hline Tauranga & 0 & 0 & 0 & 0 & 0 & 1 & 0 & 0 & 0 & 0 & 0 & 0 & 0 & 0 & 1 & 0 & 0 & 0 & 0 & 0 & 0 & 0 & 2 \\
\hline Waiwera & 1 & 2 & 0 & 0 & 0 & 0 & 0 & 0 & 0 & 0 & 0 & 0 & 0 & 0 & 0 & 0 & 0 & 0 & 0 & 0 & 0 & 0 & 3 \\
\hline Whangaehu & 10 & 0 & 0 & 0 & 0 & 0 & 0 & 0 & 0 & 0 & 0 & 0 & 1 & 0 & 0 & 0 & 0 & 0 & 0 & 0 & 0 & 0 & 11 \\
\hline $\mathrm{N}$ & 60 & 16 & 14 & 11 & 8 & 3 & 2 & 2 & 1 & 1 & 1 & 1 & 1 & 1 & 1 & 11 & 5 & 2 & 2 & 1 & 1 & 1 & 146 \\
\hline
\end{tabular}


TABLE 2.4) List of all haplotypes found in this study and base pair composition at all 23 variable sites. Site number corresponds to position on the 618 base pair fragment.

\begin{tabular}{|c|c|c|c|c|c|c|c|c|c|c|c|c|c|c|c|c|c|c|c|c|c|c|c|}
\hline Site & 16 & 49 & 59 & 118 & 184 & 217 & 235 & 271 & 337 & 340 & 343 & 364 & 433 & 448 & 454 & 478 & 484 & 505 & 532 & 538 & 549 & 562 & 586 \\
\hline A1 & $\mathrm{C}$ & $\mathrm{C}$ & $\mathrm{T}$ & $\mathrm{C}$ & A & A & $\mathrm{T}$ & $\mathrm{G}$ & A & $\mathrm{T}$ & $\mathrm{T}$ & $\mathrm{T}$ & $\mathrm{G}$ & $\mathrm{T}$ & $\mathrm{T}$ & A & $\mathrm{G}$ & $\mathrm{C}$ & $\mathrm{C}$ & $\mathrm{G}$ & $\mathrm{T}$ & $\mathrm{T}$ & $\mathrm{T}$ \\
\hline A2 & . & . & . & . & . & . & . & . & . & . & $\mathrm{C}$ & . & . & . & . & . & . & . & . & . & . & . & . \\
\hline A3 & . & . & . & . & . & . & . & . & . & . & . & . & . & . & . & . & . & . & . & A & . & . & . \\
\hline A4 & . & . & . & . & . & . & . & . & . & . & . & . & . & . & . & . & A & . & . & . & . & . & . \\
\hline A5 & . & . & . & . & . & . & . & . & . & . & . & . & A & . & . & . & . & . & . & . & . & . & . \\
\hline A6 & . & . & . & . & . & . & . & A & . & . & . & . & . & . & . & . & . & . & . & . & . & . & . \\
\hline A7 & . & $\mathrm{T}$ & . & . & . & . & . & . & . & . & . & . & . & . & . & . & . & . & . & . & . & . & . \\
\hline A8 & . & . & . & . & . & . & $\mathrm{C}$ & A & . & . & . & . & . & . & . & . & . & . & . & . & . & . & . \\
\hline A9 & . & . & . & . & $\mathrm{G}$ & . & . & . & . & . & . & . & . & . & . & . & . & . & . & . & . & . & . \\
\hline A10 & . & . & . & . & . & . & . & . & $\mathrm{G}$ & . & . & . & . & . & . & . & . & . & . & . & . & . & . \\
\hline A11 & . & . & . & . & . & . & . & . & . & . & . & . & . & . & . & $\mathrm{G}$ & . & . & . & . & . & . & . \\
\hline A12 & . & . & . & . & . & . & . & . & . & . & . & . & . & . & . & . & . & . & . & . & A & . & . \\
\hline A13 & . & . & . & . & . & . & $\mathrm{C}$ & . & . & . & . & . & . & . & . & . & . & . & . & . & . & . & . \\
\hline A14 & . & . & . & . & . & . & . & . & . & . & . & . & . & . & . & . & . & . & . & . & . & . & $\mathrm{G}$ \\
\hline B & $\mathrm{T}$ & . & . & . & . & . & $\mathrm{C}$ & A & . & $\mathrm{C}$ & $\mathrm{C}$ & . & . & . & . & . & . & $\mathrm{T}$ & $\mathrm{T}$ & . & . & A & . \\
\hline $\mathrm{C} 1$ & $\mathrm{~T}$ & . & . & . & . & $\mathrm{G}$ & . & . & . & $\mathrm{C}$ & $\mathrm{C}$ & . & A & $\mathrm{C}$ & . & . & . & $\mathrm{T}$ & $\mathrm{T}$ & . & . & A & . \\
\hline $\mathrm{C} 2$ & $\mathrm{~T}$ & . & . & . & . & . & . & . & . & $\mathrm{C}$ & $\mathrm{C}$ & $\mathrm{C}$ & A & $\mathrm{C}$ & . & . & . & $\mathrm{T}$ & $\mathrm{T}$ & . & . & A & . \\
\hline C3 & $\mathrm{T}$ & . & . & $\mathrm{T}$ & . & . & . & . & . & $\mathrm{C}$ & $\mathrm{C}$ & $\mathrm{C}$ & A & $\mathrm{C}$ & . & . & . & $\mathrm{T}$ & $\mathrm{T}$ & . & . & A & . \\
\hline C4 & $\mathrm{T}$ & . & . & . & . & $\mathrm{G}$ & . & . & . & $\mathrm{C}$ & $\mathrm{C}$ & . & A & $\mathrm{C}$ & $\mathrm{C}$ & . & . & $\mathrm{T}$ & $\mathrm{T}$ & . & . & A & . \\
\hline C5 & $\mathrm{T}$ & . & . & $\mathrm{T}$ & . & . & . & . & . & $\mathrm{C}$ & $\mathrm{C}$ & $\mathrm{C}$ & A & $\mathrm{C}$ & . & . & . & $\mathrm{T}$ & $\mathrm{T}$ & . & . & A & . \\
\hline C6 & $\mathrm{T}$ & . & $\mathrm{G}$ & . & . & $\mathrm{G}$ & . & . & . & $\mathrm{C}$ & $\mathrm{C}$ & . & A & $\mathrm{C}$ & . & . & . & $\mathrm{T}$ & $\mathrm{T}$ & . & . & A & . \\
\hline C7 & $\mathrm{T}$ & . & $\mathrm{G}$ & . & . & $\mathrm{G}$ & . & . & . & $\mathrm{C}$ & $\mathrm{C}$ & . & A & $\mathrm{C}$ & $\mathrm{C}$ & . & . & $\mathrm{T}$ & $\mathrm{T}$ & . & . & $\mathrm{A}$ & . \\
\hline
\end{tabular}




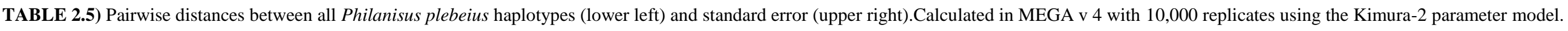

\begin{tabular}{|c|c|c|c|c|c|c|c|c|c|c|c|c|c|c|c|c|c|c|c|c|c|c|}
\hline & & & 3) & & & & 7) & & & 0) & 1) & & 3) & 4) & 5) & & 7) & 8) & 9) & 0) & 1) & 2) \\
\hline $\mathrm{A} 1$ & & 0.0016 & 0.0015 & .0015 & 0.0016 & 0.0015 & 0.0016 & 0.0023 & 0.0016 & 0.0015 & 0.0016 & 0.0016 & 0.0016 & 0.0016 & 0.0045 & 0.0047 & 0.0047 & 0.0049 & 0.0049 & .0044 & 0.005 & 0.005 \\
\hline ) $\mathrm{A} 2$ & .0016 & & 0.0022 & .0022 & .0022 & 0.0022 & 0.0022 & 0028 & 0022 & 0.0022 & 0.0023 & 0021 & .0023 & 0.0023 & 0.0043 & 0044 & 0.0044 & 0.0047 & 0.0046 & 0.0041 & 0.0047 & 0.005 \\
\hline 3) $\mathrm{A} 3$ & 0.0016 & 0.0032 & & 0.0021 & 0.0022 & 0.0021 & 0.0022 & 0.0027 & 0.0022 & 0.0021 & 0.0023 & 0.0022 & 0.0023 & 0.0021 & 0.0048 & 0.005 & 0.0050 & 0.0053 & 0.0052 & 0.0047 & 0.0053 & 0.0055 \\
\hline A4 & . 0016 & 0.0032 & 0.0032 & & 0.0021 & 0.0021 & 0.0022 & 0.0027 & 0.0022 & 0.0022 & 0.0022 & 0.0021 & 0.0022 & 0.0022 & 0.0048 & 0.0049 & 0.0049 & 0.0052 & 0.0052 & 0.0047 & 0.0052 & 0.0055 \\
\hline A5 & 0.0016 & 0.0032 & 0.0032 & 0.0032 & & 0.0022 & 0.0022 & 0.0028 & 0.0021 & 0.0022 & 0.0022 & 0.0022 & 0.0024 & 0.0022 & 0.0049 & .0044 & 0.0044 & 0.0047 & 0.0046 & .0041 & 0.0047 & 0.0050 \\
\hline A6 & .0016 & 0.0032 & 0.0032 & 0.0032 & 0.0032 & & 0.0023 & 0.0016 & 0.0022 & 0.0022 & 0.0022 & 0.0021 & 0.0023 & 0.0021 & 0.0042 & 0.0050 & 0.0050 & 0.0052 & 0.0052 & 0.0047 & 0.0052 & 0.0055 \\
\hline A7 & 0.0016 & 0.0032 & 0.0032 & 0.0032 & 0.0032 & 0.0032 & & 0.0028 & 00023 & 0.0022 & 0.0023 & 00073 & 0.0023 & 0.0022 & 0.0048 & 0005 & 0.0049 & 0.0051 & 0.0052 & 0.0046 & 0.0052 & 0.0055 \\
\hline A8 & .0032 & 0.0049 & 0.0049 & 0.0049 & 0.0049 & 0.0016 & 0.0049 & & 要 & 0.0027 & 0.0028 & 0.0021 & 0.0015 & 0.0027 & 0.0038 & 0.0053 & 0.0053 & 0.0056 & 0.0055 & 0.0051 & 0.0056 & 0.0058 \\
\hline A9 & 0016 & 0.0032 & 0.0032 & 0.0032 & 0.0032 & 0.0032 & 0.0032 & 0.0049 & & 0.0022 & 0.0022 & 0.0023 & 0.0023 & 0.0022 & 0.0048 & 0.0049 & 0.0049 & 0.0051 & 0.0051 & 0.0046 & 0.0052 & 0.0054 \\
\hline 10) $\mathrm{A} 10$ & 0.0016 & 0.0032 & 0.0032 & 0.0032 & 0.0032 & 0.0032 & 0.0032 & 0.0049 & 0.0032 & & 0.0021 & 0.0021 & 0.0022 & 0.0022 & 0.0048 & 0.0050 & 0.0050 & 0.0052 & 0.0052 & 0.0047 & 0.0052 & 0.0055 \\
\hline 1) $\mathrm{A} 11$ & 0.0016 & 0.0032 & 0.0032 & 0.0032 & 0.0032 & 0.0032 & 0.0032 & 0.0049 & 0.0032 & 0.0032 & & 00020 & 0.0023 & 0.0022 & 0.0048 & 0.0049 & 0.0049 & 0.0052 & 0.0052 & 0.0047 & 0.0052 & 0.0055 \\
\hline 2) $\mathrm{A} 12$ & .0016 & 0.0032 & 0.0032 & 0.0032 & 0.0032 & 0.0032 & 0.0032 & 0.0049 & 0.0032 & 0.0032 & 0.0032 & & 0.0023 & 0.0023 & 0.0048 & 0.0049 & 0.0049 & 0.0051 & 0.0052 & 0.0046 & 0.0052 & 0.0055 \\
\hline 3) $\mathrm{A} 13$ & .0016 & 0.0032 & 0.0032 & 0.0032 & 0.0032 & 0.0032 & 0.0032 & 0.0016 & 0.0032 & 0.0032 & 0.0032 & 0.0032 & & 0.0023 & 0.0042 & 0.005 & 0.005 & 0.0053 & 0.0053 & 0.0048 & 0.0053 & 0.0056 \\
\hline 4) 414 & 0.0016 & 0.0032 & 0.0032 & 0.0032 & 0.0032 & 0.0032 & 0.0032 & 0.0049 & 0.0032 & 0.0032 & 0.0032 & 0.0032 & 0.0032 & & 0.0049 & 0.005 & 0.0051 & 0.0053 & 0.0053 & 0.0048 & 0.0053 & 0.0056 \\
\hline 5) $B$ & 0.0131 & 0.0114 & 0.0148 & 0.0148 & 0.0148 & 0.0114 & 0.0148 & 0.0098 & & & 0.0148 & 0147 & 0.0114 & & & & 0.0035 & 0.0039 & 0.0039 & 0.0038 & & 0.0043 \\
\hline 6) $\mathrm{C} 1$ & 0.0148 & 0.0131 & 0.0164 & 0.0164 & 0.0131 & 0.0164 & 0.0164 & 0.0181 & .0164 & 0.0164 & 0.0164 & 0.0164 & 0.0164 & 0.0164 & 0.0082 & & 0.0022 & 0.0027 & 0.0015 & 0.0027 & 0.0015 & 0.0023 \\
\hline 7) $\mathrm{C}$ & 0.0148 & 0.0131 & 0.0164 & 0.0164 & 0.0131 & 0.0164 & 0.0164 & 0.0181 & 0.0164 & 0.0164 & 0.0164 & 0.0164 & 0.0164 & 0.0164 & 0.0082 & 0.0032 & & 0.0016 & 0.0027 & 0.0016 & 0.0027 & 0.0032 \\
\hline o) $r 2$ & 0164 & 0.0148 & 0.0181 & 0.0181 & 0.0148 & 0.0181 & 0.0181 & 0.0198 & 0018 & 0.0181 & 0.0181 & 0181 & 0.0181 & 0.0181 & 0.0098 & 0.0049 & 0.0016 & & 0.0032 & 0.0023 & 0.0031 & 0.0036 \\
\hline 19) $(4$ & 0.0164 & 0.0148 & 0.0181 & 0.0181 & 0.0148 & 0.0181 & 0.0181 & 0.0198 & 0.0181 & 0.0181 & 0.0181 & 0.0181 & 0.0181 & 0.0181 & 0.0098 & 0.0016 & 0.0049 & 0.0065 & & 0.0031 & 0.0023 & 0.0015 \\
\hline 0) $\mathrm{C} 5$ & 0.0131 & 0.0115 & 0.0148 & 0.0148 & 0.0115 & 0.0148 & 0.0148 & 0.01 & 0.0148 & 0.0148 & 0.0148 & 0.0 & 0.0148 & 0.0148 & 0.0098 & 0.0049 & 0.0016 & 0.0032 & 0.0065 & & 0.0031 & 0.0035 \\
\hline 1) $\mathrm{C} 6$ & 0.0164 & 0.0147 & 0.0181 & 0.0181 & & 0.0181 & 0.0181 & 0.0197 & & & & & & & 0.0098 & & 0.0049 & 0.0065 & 0.0032 & 0.0065 & & 0.0015 \\
\hline 2) & 0.0181 & 0.0164 & 0.0197 & 0.0197 & 0.0164 & 0.0197 & 0.0197 & 0.0214 & 0.0197 & 0.0197 & 0.0197 & 0.0197 & 0.0197 & 0.0197 & 0.0114 & 0.0032 & 0.0065 & 0.0081 & 0.0016 & 0.0081 & 0.0016 & \\
\hline
\end{tabular}


TABLE 2.6) Mean distances between and within groups, and within all of Philanisus plebeius. Calculated in MEGA v 4 with 10,000 replicates using the Kimura-2 parameter model

\begin{tabular}{llrl}
\hline Grouping & Between/Within Groups & D & \multicolumn{2}{c}{ SE } \\
\hline Philanisus plebeius & Within & 0.01 & 0.002 \\
Group A & Within & 0.003 & 0.001 \\
Group C & Within & 0.009 & 0.002 \\
Group A-B & Between & 0.014 & 0.004 \\
Group A-C & Between & 0.019 & 0.003 \\
Group B-C & Between & 0.011 & 0.011
\end{tabular}

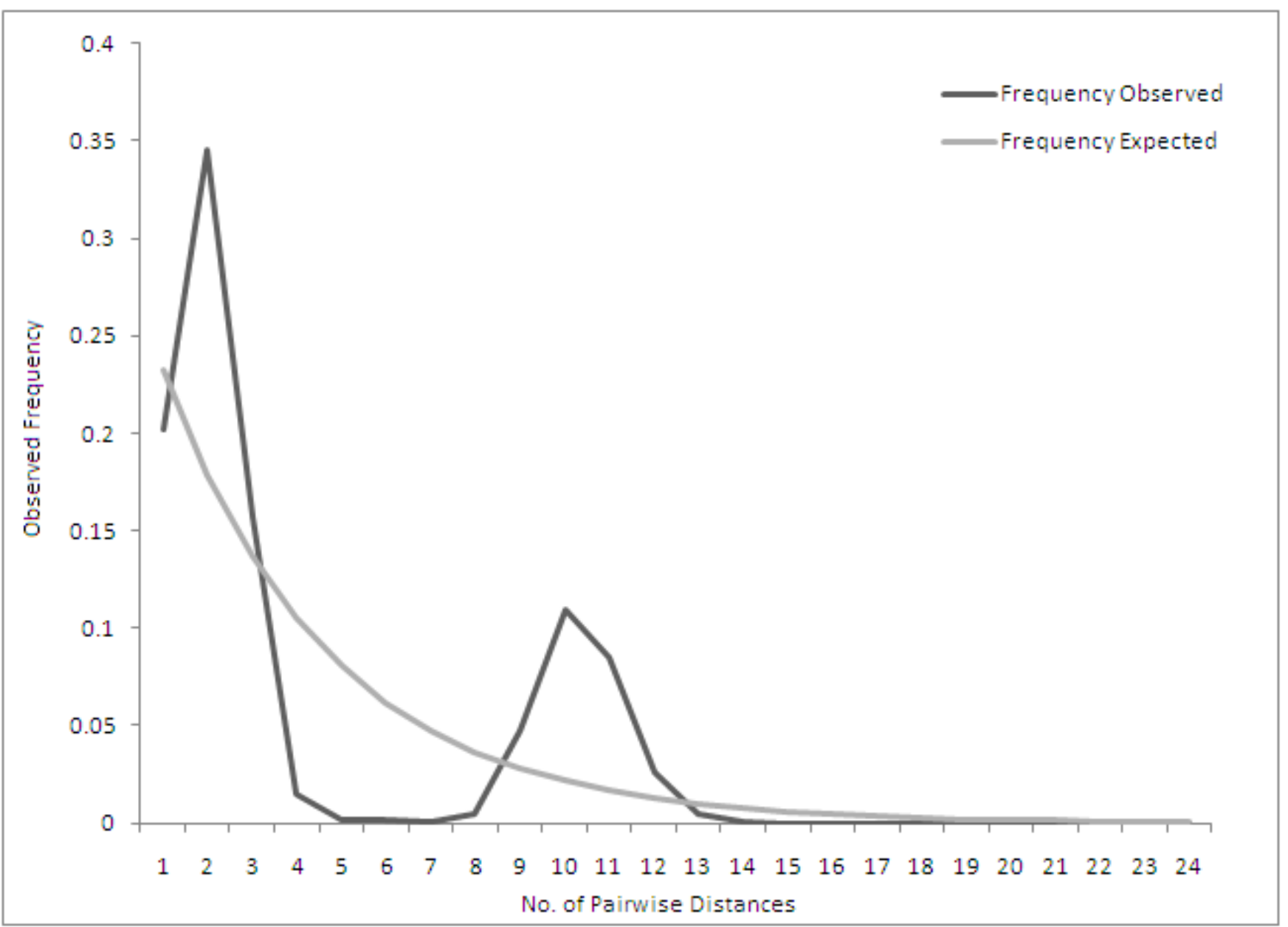

FIG 2.2) Mismatch distribution chart of $P$. plebeius using all 146 sequences. Distance (Pairwise estimate) shown with observed frequency. Expected frequency calculated in DNAsp represents that expected in a stable population. 
TABLE 2.7) List of sequence statistics calculated for between haplotype groupings. * indicates a significant $P$ value.

\begin{tabular}{lclll}
\hline Grouping & Tajimas D & P Value & Fu's $F_{s}$ & P value \\
\hline AllHaplotypes & -0.15097 & $>0.10$ & -20.236 & $<0.01^{*}$ \\
Haplogroup A only & -1.91810 & $<0.05^{*}$ & -18.404 & $<0.01^{*}$ \\
Haplogroup B only & 0.45159 & $>0.10$ & -4.774 & $<0.01^{*}$
\end{tabular}

TABLE 2.8) List of all AMOVA statistics calculated in Arequin. * indicates a significant $P$ value

\begin{tabular}{|c|c|c|c|c|c|}
\hline Source of Variation & df & Sum of Squares & Variance components & Percentage Variation & $\mathrm{P}$ \\
\hline \multicolumn{6}{|l|}{ Upper North Island Groupings } \\
\hline Among Groups (a) & 3 & 1.557 & 0.02056 & 8.54809 & 0.10129 \\
\hline Among Populations within Groups (b) & 2 & 0.299 & -0.00816 & -3.39024 & 0.5797 \\
\hline Within Populations (c) & 76 & 17.339 & 0.22814 & 94.84215 & 0.02376 \\
\hline Total & & 19.195 & 0.24055 & & \\
\hline \multicolumn{6}{|l|}{ North-South Groupings } \\
\hline Among Groups (a) & 2 & 8.113 & 0.20963 & 51.29439 & 0.1199 \\
\hline Among Populations within Groups (b) & 6 & 1.885 & 0.01093 & 2.67518 & 0.03931 \\
\hline Within Populations (c) & 97 & 18.248 & 0.18812 & 46.03044 & $<0.01$ \\
\hline Total & & 28.245 & 0.40869 & & \\
\hline
\end{tabular}




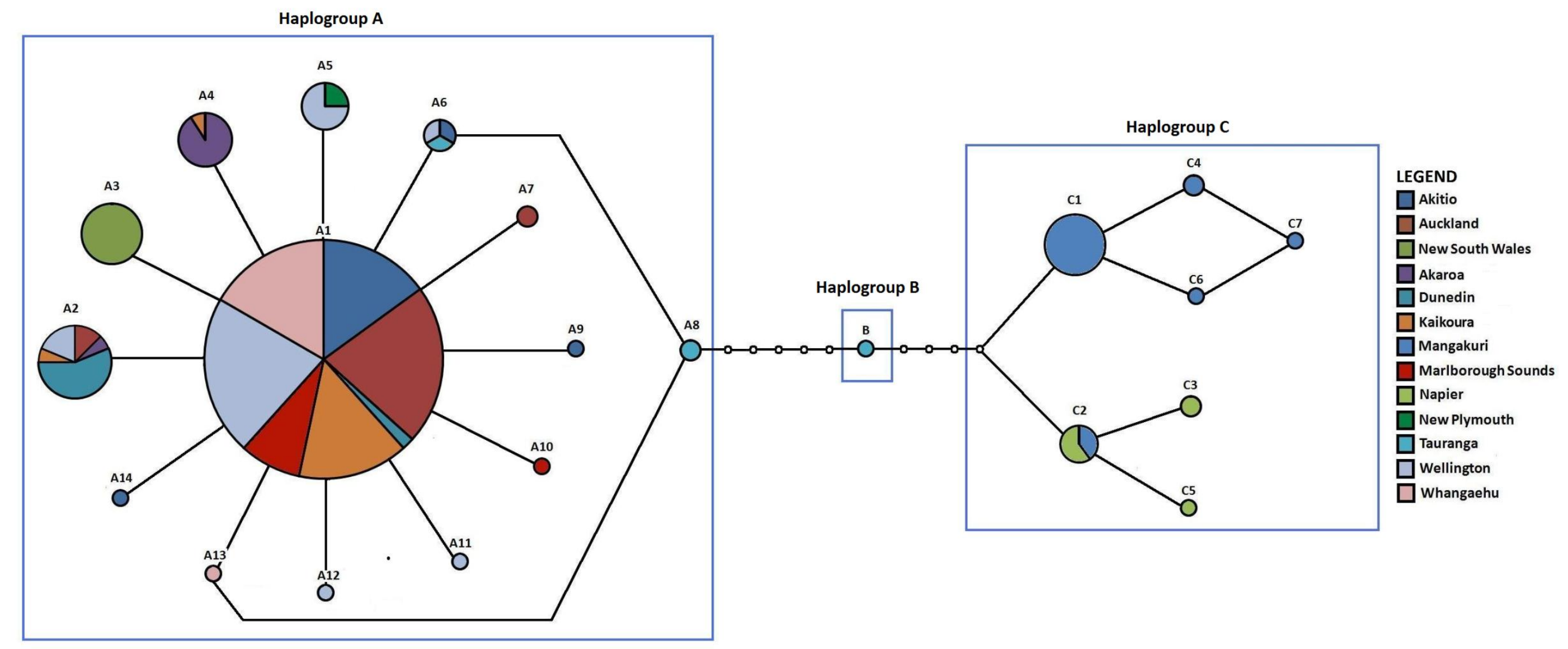

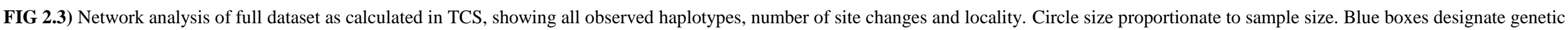
scope of each haplogroup 


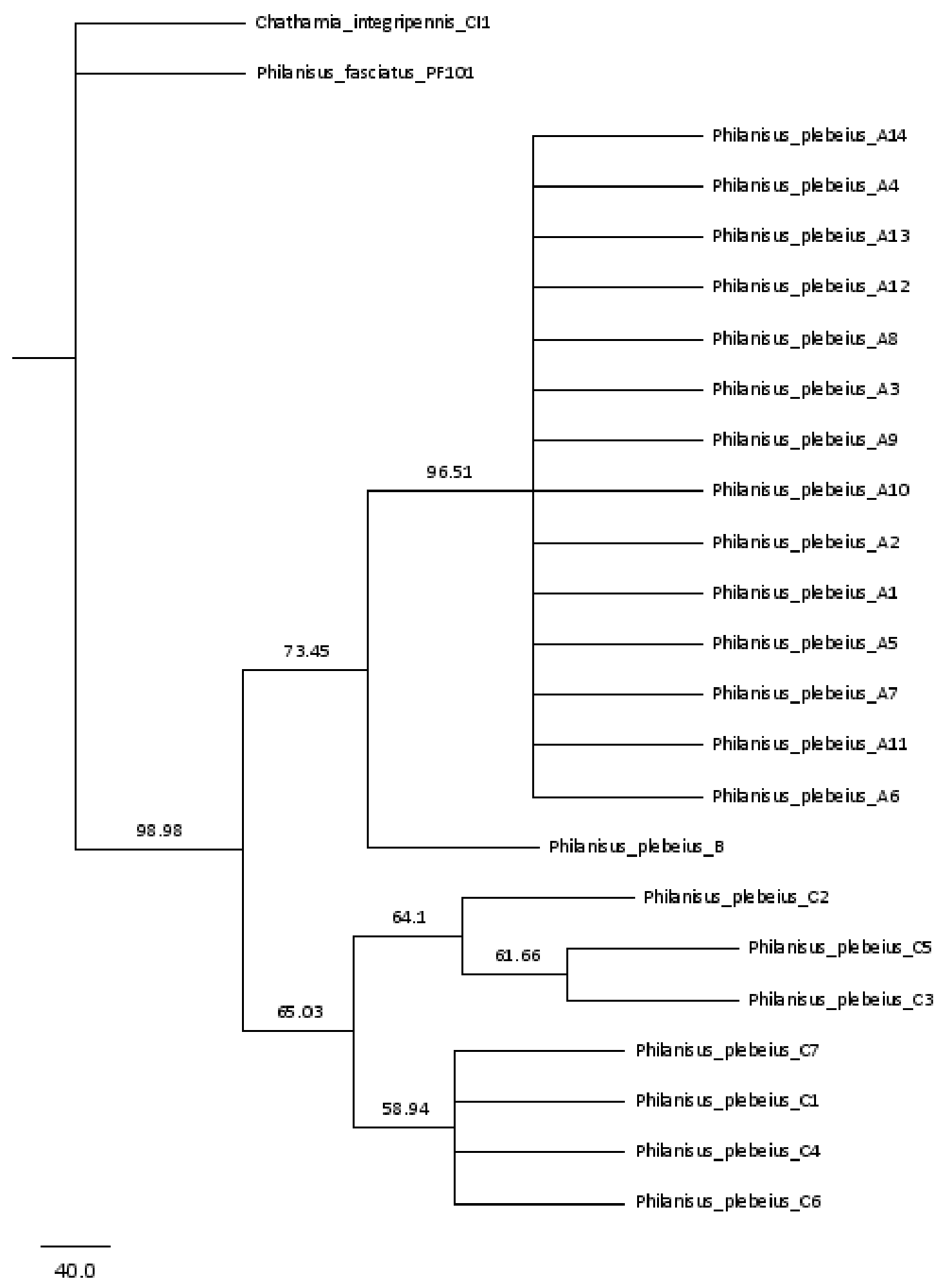

FIG 2.4) Bootstrap consensus Maximum Parsimony (MP) tree of all Philanisus plebieus haplotypes (10,000 replicates, Heuristic search logarithm) as inferred in PAUP*. Bootstrap values (\%) are shown. 
Chathami_integripennis_Cl1

Philanisus_fasciatus_PF101

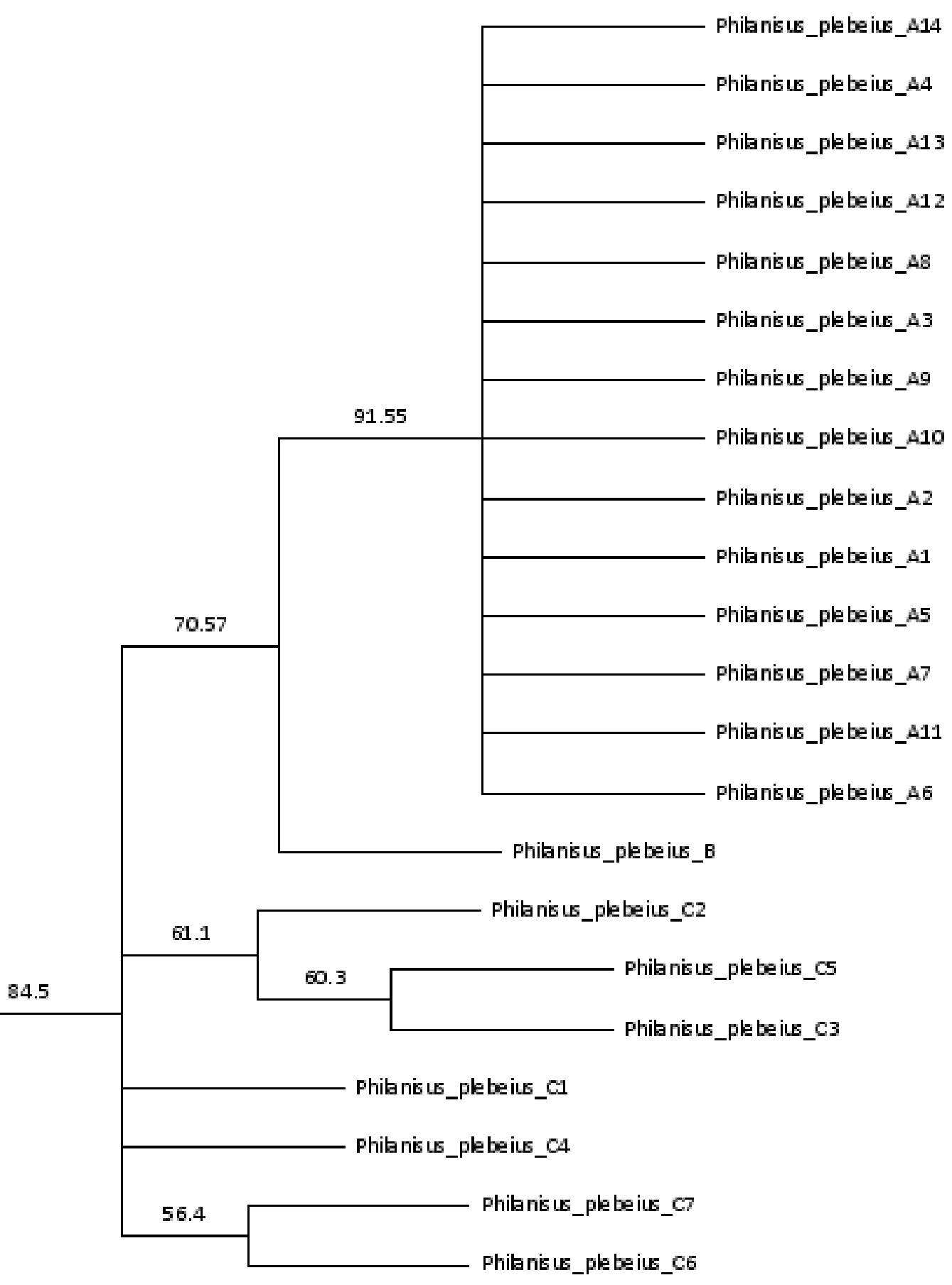

40.0

FIG 2.5) Bootstrap consensus Maximum likelihood (ML) tree of all Philanisus plebeius haplotypes (10,000 replicates, Heuristic search logarithm) as inferred in PAUP*. Bootstrap values (\%) are shown. 


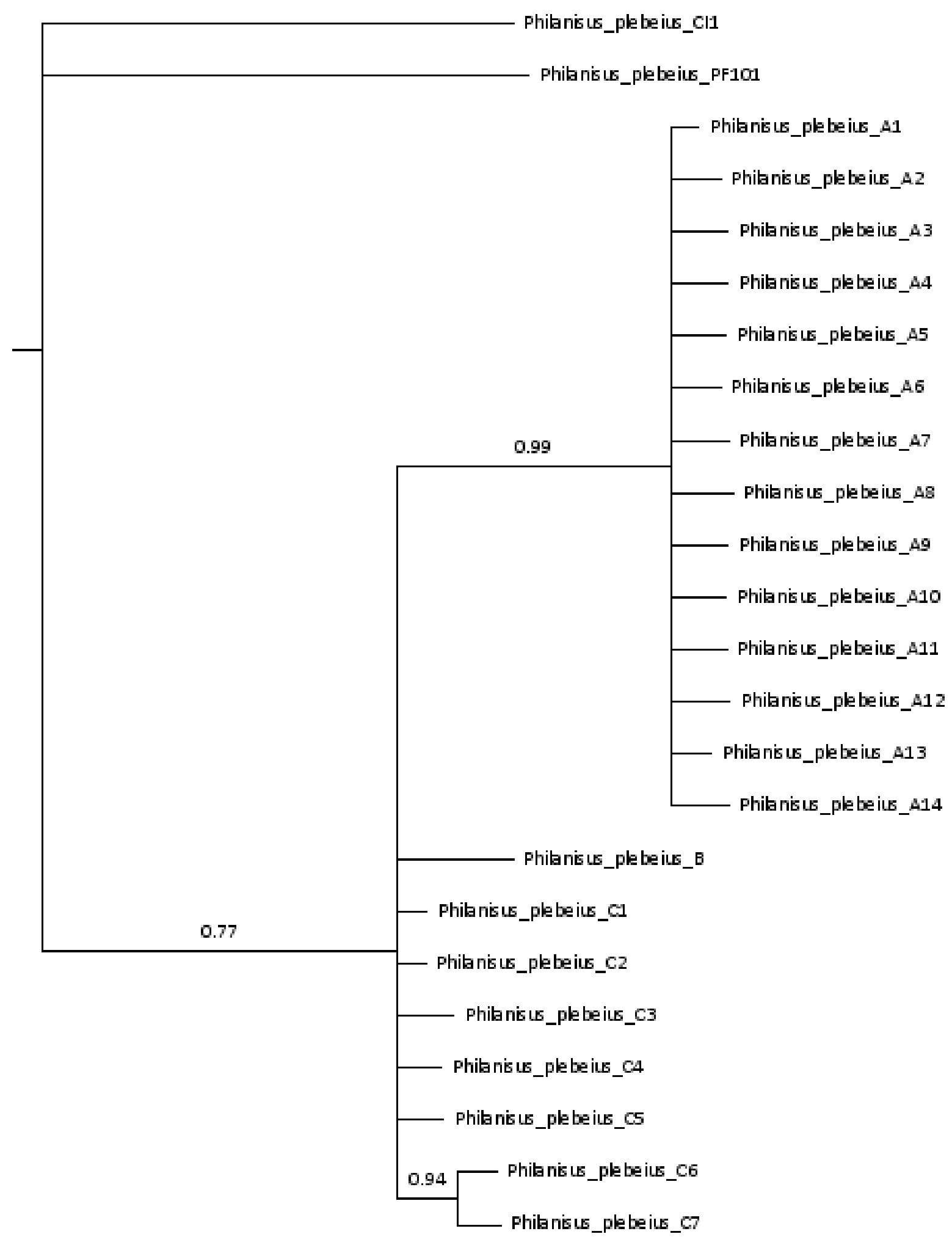

FIG 2.6) Bayesian analysis tree of all Philanisus plebeius haplotypes as analysed through MrBayes. Posterior Bayesian probability indices are shown. 


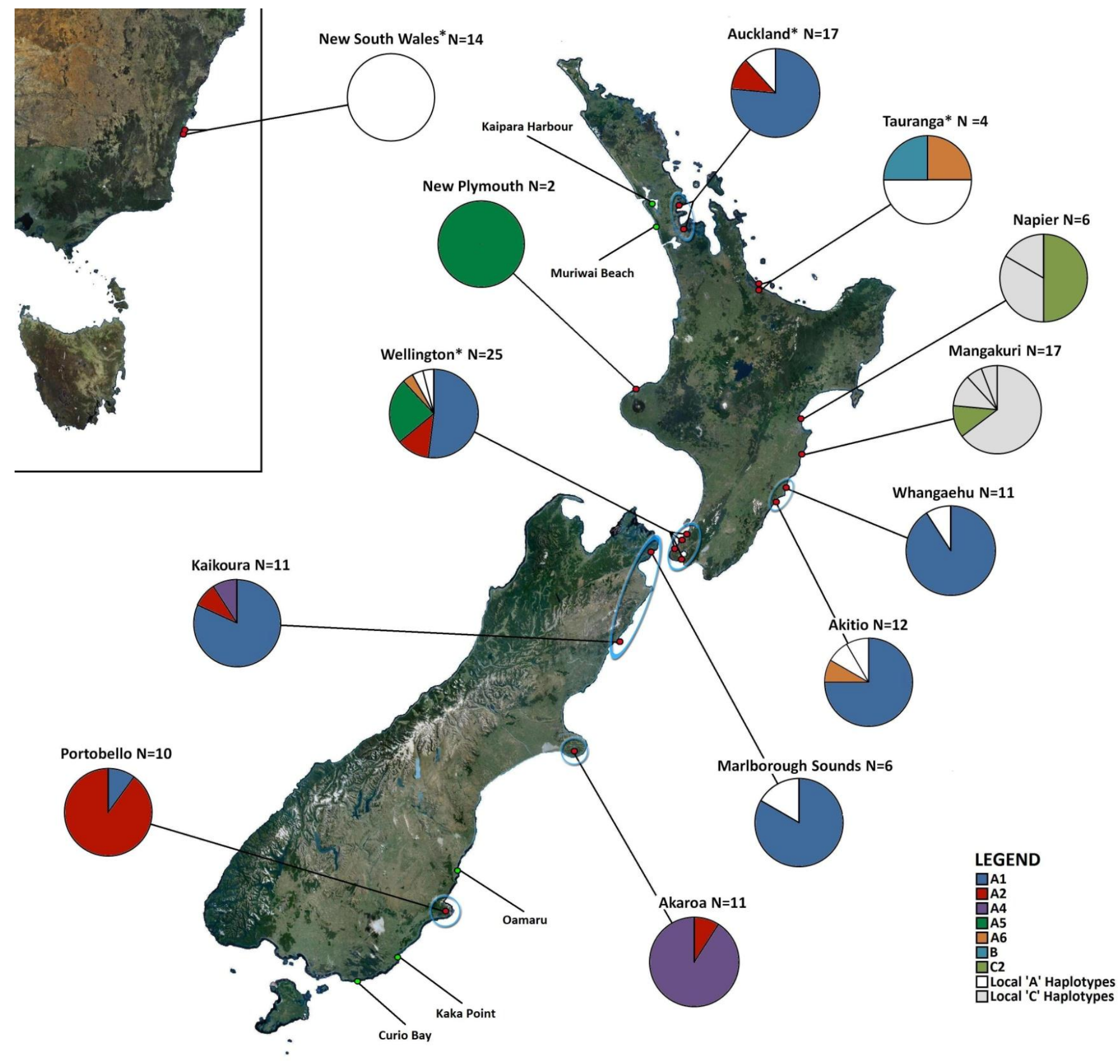

FIG 2.7) Map showing all collection sites and proportion of observed haplotypes. Legend shows haplotype codes. Sample size shown. Sites with* designate combined localities (refer to Table 2.1 for more detail). Circles show areas used for AMOVA analyses (first top four used for first AMOVA only, then combined and compared with the bottom two for the second analysis). Green points show areas where lighttrapping was attempted but no samples successfully collected (evidence for population absences in these regions). 


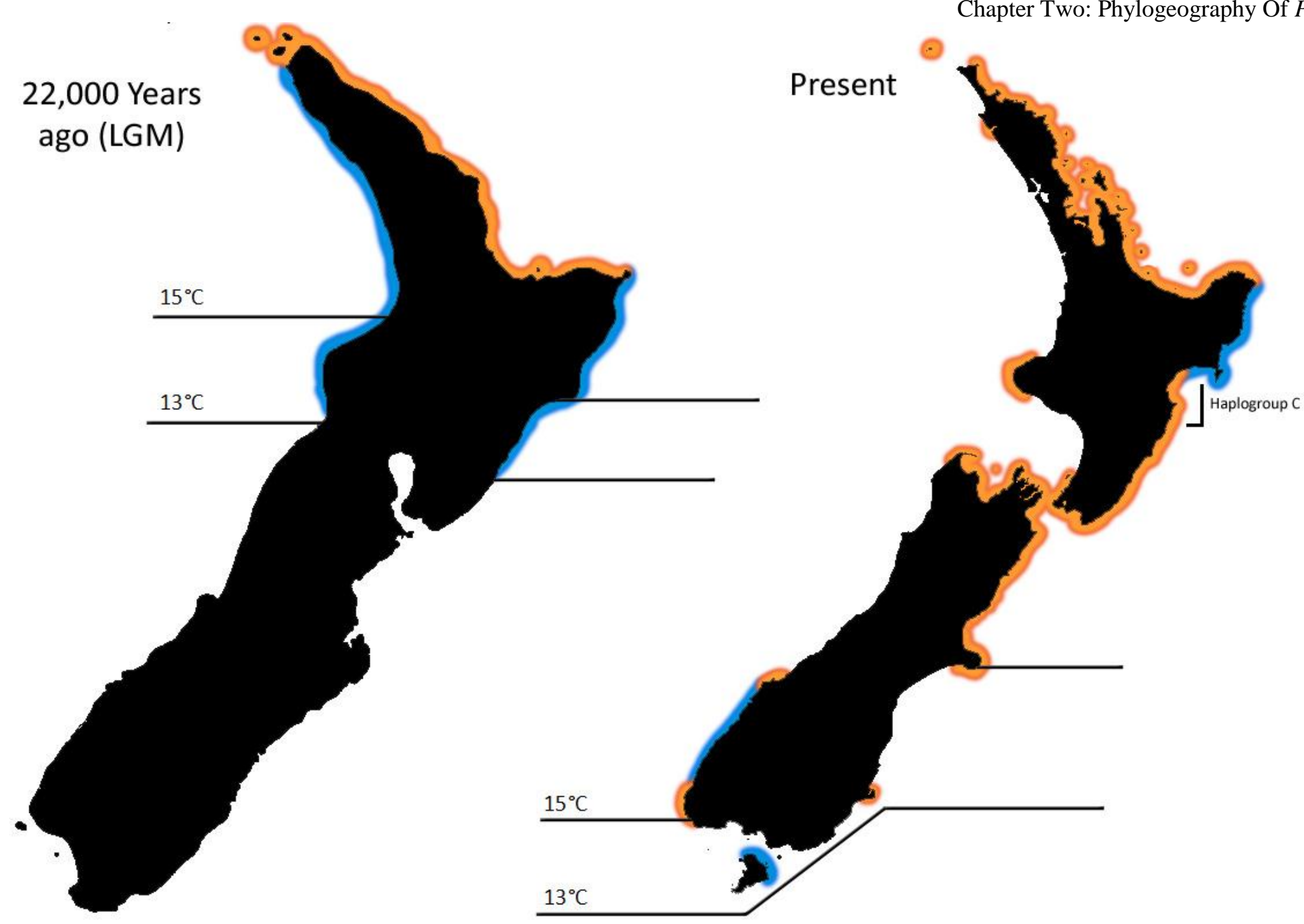

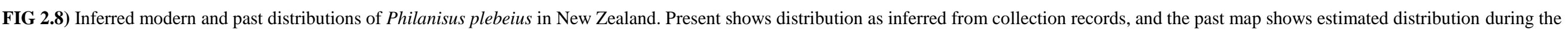

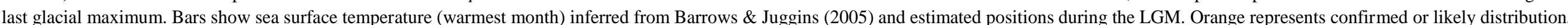

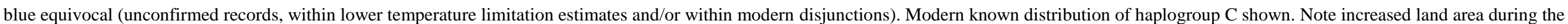
LGM. 


\subsection{References:}

Alloway BV, Lowe DJ, Barrell DJA, Newham RM, Almon PC, Augustinus PC, Bertler NAN, Carter L, Litchfield NJ, McGlone MS, Shulmeister J, Vandergoes MJ, Williams PW and NZINTIMATE members. Towards a climate event stratigraphy for New Zealand over the past 30 000 ears (NZ-INTIMATE project). Journal of Quaternary Science 22: 9-35

Anderson DT, Fletcher MJ, Lawson-Kerr C (1976).A marine caddisfly, Philanisus plebeius, ovipositing in a starfish, Patiriella exigua. Search 7: 483-484

Anderson DT, Lawson-Kerr (1977). The embryonic development of the marine caddis fly Philanisus plebeius Walker (Trichoptera: Chathamiidae). Biological Bulletin 153: 98-105

Andersen NM, Cheng L, Damgarrd J, Sperling FAH (2000). Mitochondrial DNA sequence variation and phylogeography of oceanic insects (Hemiptera: Gerridae: Halobates spp.) Marine Biology 136: $321-430$

Apte S, Gardner JPA (2002) Population genetic subdivision in the New Zealand greenshell mussel (Perna canaliculus) inferred from single-strand conformation polymorphism analysis of mitochondrial DNA. Molecular Ecology 11: 1617-1628

Avise JC, Ball AJ, Ball RM, Bermingham E, Lamb T, Neigel JE, Reeb CA, Saunders NC (1987). Intraspecific phylogeography: the mitochondrial DNA bridge between population genetics and systematics. Annual Review of Ecology and Systematics 18: 489-522

Ayers KL, Waters JM (2005).Marine biogeographic disjunction in central New Zealand. Marine Biology 147: 1045-1052

Barrows TT, Juggins S (2005). Sea-surface temperatures around the Australian margin and Indian Ocean during the Last Glacial Maximum. Quaternary Science Reviews 24: 1017-1047

Baker AM, Williams SA, Hughes JM (2003). Patterns of spatial genetic structuring in a hydropsychid caddisfly (Cheumatopsyche sp. AV1) from southeastern Australia. Molecular Ecology 12: 3313-3324

Bradford JM (1983). Physical and chemical oceanographic observations off Westland, New Zealand. June 1978. New Zealand Journal of Marine and Freshwater Research 17: 71-81

Bretschko G (1981). Pontomyia Edwards (Diptera: Chironomidae), a member of the coral reef community at Carry Bow Cay, Belize. Smithsonian Contributions to the Marine Sciences 12: 381-385

Brodin Y, Andersson MH (2009). The marine splash midge Telmatogon japonicas (Diptera; Chironomidae) - extreme and alien? Biological Invasions 11: 1311-1317

Brower AVZ (1994). Rapid morphological radiation and convergence and convergence among races of the butterfly Heliconius erato inferred from patterns of mitochondrial DNA evolution. Proceedings of the National Academy of Sciences of the USA 91: 6491-6495 
Brook MS, Schulmeister J, Corw TVH, Zondervan A (2008). First cosmogenic ${ }^{10} \mathrm{Be}$ constraints on LGM glaciation on New Zealand's North Island: Park Valley, Tararua Range. Journal of Quaternary Science 23: 707-712

Denton GH, RF Anderson RF, Toggweiler JR, Edwards RL, Schaefer JM, Putnam AE (2010). The Last Glacial Termination. Science 328: 1652-1656

Buckley TR, Marske KA, Attanayake D (2009). Identifying glacial refugia in a geographic parthenogen using palaeoclimate modelling and phylogeography: the New Zealand stick insect Argosarchus horridus (White). Molecular Ecology 18: 4650-4663

Cáceres C, Segura DF, Vera MT, Wornoayporn V, Cladera JL, Teal P, Sopountzis P, Bourtzis K, Zacharopoulou A, Robinson AS (2009). Incipient speciation revealed in Anastrepha fraterculus (Diptera; Tephritidae) by studies on mating compatibility, sex pheromones, hybridization, and cytology. 97: 152-165

Carter L, Garlick RD, Sutton P, Chiswell S, Oien NA, Stanton BR (1998). Ocean circulation New Zealand. NIWA chart, Miscellaneious Series No. 76. National Institute of Water and Atmospheric Research LTD, Wellington, New Zealand.

Cheng L (editor) (1976). Marine insects. North-Holland Publishing Co., Amsterdam.

Cheng, L (1985). Biology of Halobates (Heteroptera: Gerridae). Annual Review of Entomology 30: 111-35

Cheng L, Collins JD (1980). Observations on Behavior, Emergence and Reproduction of the Marine Midges Pontomyia (Diptera: Chironomidae). Marine Biology 58: 1-5

Clement M, Posada D, Crandall K (2000). TCS: a computer program to estimate gene genealogies. Molecular Ecology 9: 1657-1660

Colbo MH (1996). Chironomidae from marine coastal environments near St. John's, Newfoundland, Canada.Hydrobiologia 318: 117-122

Collier K (1993). Review of the status, distribution, and conservation of freshwater invertebrates in New Zealand. New Zealand Journal of Marine and Freshwater Research 27: 339-356

Collier KJ, Smith BJ (1998). Dispersal of adult caddisflies (Trichoptera) into forests alongside three New Zealand streams. Hydrobiologia 361: 53-65

Cooper A, Cooper RA (1993). The New Zealand biota: historical background and new research. TRENDS in Ecology and Evolution 8: 429-433

Damgaard J, Anderson NM, Sperling FAH (2000).Phylogeny of sea skaters, Halobates Escholtz (Hemiptera, Gerridae), based on mtDNA sequence and morphology. Zoological Journal of the Linnean Society 130: 511-526

Erwin TL (1982). Tropical forests: their richness in Coleoptera and other species. Coleopterist's Bulletin 36: 74-75

Ewans KC, Kibblewhite AC (1990). An Examination of Fetch-Limited Wave Growth off the West Coast of New Zealand by a Comparison with the JONSWAP Results. Journal of Physical Oceanography 20: 1278-1296 
Farris JS (1970). Methods for computing Wagner trees. Systematic Zoology 18: 274-385

Fleming CA (1979). The geological history of New Zealand and its life. Auckland University Press, Auckland.

Flint, OS Jr., Giberson DJ (2005). Salt marsh caddisflies: discovery of the larva and larval habitat of Limnephilus ademus in salt marshes in Prince Edward Island, Canada. Proceedings of the 11th International Symposium on Trichoptera pp 121-130

Folmer O, Black M, Hoeh W, Lutz R, Vrijenhoek R (1994). DNA primers for amplification of mitochondrial cytochrome c oxidase subunit I from diverse metazoan invertebrates. Molecular Marine Biology and Biotechnology 3: 294-299

Foster SP, Dugdale JS, White CS (1991). Sex pheromones and the status of greenheaded and brownheaded leafroller moths in New Zealand. New Zealand Journal of Zoology 18: 63-74

Felsenstein J (1981). Evolutionary trees from DNA sequences: a maximum likelihood approach. Journal of Molecular Evolution 17: 386:376

Fraser CI, Nikula R, Spencer HG, Waters JM (2009). Kelp genes reveal effects of subantarctic sea ice during the Last Glacial Maximum. Proceedings of the National Academy of Sciences of the USA 106: 3249-3253

Fraser CI, Nikula R, Spencer HG, Waters JM (2010). Oceanic rafting by a coastal community. Proceedings of the Royal Society, Series B: Biological Sciences Supplement pp 1-5

Fu YX (1997). Statistical tests of neutrality mutations against population growth, hitchhiking and background selection. Genetics 147: 915-925

Garbary DJ, Jamieson MM, Fraser SJ, Ferguson CA, Cranston PS (2005). Ascophyllum (Phaeophyceae) and its symbionts. IX. A novel symbiosis between Halocladius variabilis (Chironomidae, Insecta) and Elachista fucicola (Elachistacea, Phaeophyceae) from marine rocky shores of Nova Scotia. Symbiosis 40: 61-80

Gardner RC, de Lange PJ, Keeling DJ, Bowala T, Brown HA, Wright SD (2004). A late Quaternary phylogeography for Metrosideros (Myrtaceae) in New Zealand inferred from chloroplast DNA haplotypes. Biological Journal of the Linnaean Society 83: 399-412

Goldstein SJ, Schiel DR, Gemmell NJ (2006). Comparative phylogeography of coastal limpets across a marine disjunction in New Zealand. Molecular Ecology 15: 3259-3268

Gratton P, Konopiński MK, Sbordoni V (2008). Pleistocene evolutionary history of the Clouded Apollo (Parnassius mnemosyne). Molecular Ecology 17: 4228-4262

Griffith MB, Barrows EM, Perry SA (1998). Lateral Dispersal of Adult Aquatic Insects (Plecoptera, Trichoptera) Following Emergence from Headwater Streams in Forested Appalachian Catchments. Annals of the Entomological Society of America 91: 195-201

Greig MJ, Ridgeway NM, Shakespeare BS (1988). Sea surface temperature variations at coastal sites around New Zealand. Zealand Journal of Marine and Freshwater Research 22: 391-400

Grimaldi D, Engel MS (2005).Evolution of the Insects. Cambridge University Press, New York. 
Hare KM, Daugherty $\mathrm{CH}$, Chapple (2008). Comparative phylogeography of three skink species (Oligosoma moco, O. smithi, O. suteri: Reptilia: Scincidae) in northeastern New Zealand. MolecularPhylogenetics and Evolution 46: 303-315

Hashitomo H (1976). Non-biting midges of marine habitats (Diptera: Chironomidae). In: L. Cheng (editor), Marine Insects. North Holland Publishing Co., Amsterdam pp 377-414

Hart DE, Bryan KR (2008).New Zealand coastal system boundaries, connections and management.New Zealand Geographer 64: 129-143

Heath RA (1982). A review of the physical oceanography of the seas around New Zealand. New Zealand Journal of Marine and Freshwater Research 19: 79-124

Heath RA (1984). Tidal observations on the West Coast, South Island, New Zealand. New Zealand Journal of Marine and Freshwater Research 18: 251-261

Hickey AJR, Lavery SD, Hannan DA, Baker HCS, Clements KD (2009). New Zealadn triplefin fishes (family Tripterygiidae): contrasting populations structure and mtDNA diversity within a marine species flock. Molecular Ecology 18: 680-696

Hogg ID, Smith BJ, Banks JC, Dewaard JR, Hebert PDN (2009). Testing use of mitochondrial COI sequences for the identification and phylogenetic analysis of New Zealand caddisflies (Trichoptera). New Zealand Journal of Marine and Freshwater Research 43: 1137-1146

Hudson GV (1904). New Zealand Neuroptera. West, Newman \& Co., London.

Huelsenbeck JP, Ronquist F (2001). MRBAYES: Bayesian inference of phylogenetic trees. Bioinformatics 17: 754-755

Ikawa T, Okubo A, Okabe H, Cheng L (1998). Oceanic diffusion and the pelagic insects Halobates spp. (Gerridae: Hemiptera). Marine Biology 131: 195-201

Jackson JK, Resh VH (1991). Periodicity in mate attraction and flight activity of three species of caddisflies (Trichoptera). Journal of the North American Benthological Society 10: 198-209

Jackson JK, Resh (1998). Morphologically Cryptic Species Confound Ecological Studies of the Caddisfly Genus Gumaga (Trichoptera: Sericostomatidae) in Northern California. Aquatic Insects 2: 69-84

Johanson KA, Kjer K, Malm T (2009). Testing the monophyly of the New Zealand and Australian endemic family Conoesucidae Ross based on combined molecular and morphological data (Insecta: Trichoptera: Sericostostomatoidea). Zoologica Scripta 38: 563-573

Jones TC, Gemmill EC, Pilditch CA (2008). Genetic variability of New Zealand seagrass (Zostera muelleri) assessed at multiple spatial scales. Aquatic Botany 88: 39-46

Kaiser TS, Heckel DG (2009). Isolation of 10 polymorphic microsatellite loci in the marine midge Clunio maritimus (Chironomidae, Diptera) and their efficient characterization by heteroduplex analysis.Molecular Ecology Resources 9: 195-198

Kefford BJ, Dalton A, Palmer CG, Nugegoda D (2004).The salinity tolerance of eggs of selected aquatic macroinvertebrates in south-east Australia and South Africa. Hydrobiologia 517: 179192 
Kelly LC, Bilton DT, Rungle SD (2001). Population structure and dispersal in the Canary Island caddisfly Mesophylax aspersus (Trichoptera, Limnephilidae). Heredity 86: 370-377

Kelly LC, Rundle, Bilton DT (2002). Genetic population structure and dispersal in Atlantic Island caddisflies. Freshwater Biology 47: 1642-1650

King KJ, Young KD, Waters JM, Wallis GP (2003). Preliminary genetic analysis of koaro (Galaxias brevipennis) in New Zealand lakes: Evidence for allopatric differentiation among lakes but little population subdivision within lakes. Journal of the Royal Society of New Zealand 33: 591-600

King DNT, Nichol SL, Hume TM (2006). Rapid Onshore Sand Flux in a High Energy Littoral Cell: Piha Beach, New Zealand. Journal of Coastal Research 22: 1360-1369

Kubow KB, Robinson CT, Shama LNS, Jokela J (2010). Spatial scaling in the phylogeography of an alpine caddisfly, Allogamus uncatus, within the central European Alps. Journal of the North American Benthological Society 29: 1089-1099

Kovats Z, Ciborowski J, Corkum L (1996). Inland dispersal of adult aquatic insects. Freshwater Biology 36: 265-276

Kumar K, Dudley J, Nei M, Kumar S (2007). MEGA4: Molecular Evolutionary Genetics Analysis software version 4.0. Molecular Biology and Evolution 24: 1596-1599.

Kumar K, Dudley J, Nei M, Kumar S (2008). MEGA: A biologist-centric software for evolutionary analysis of DNA and protein sequences. Briefings in Bioinformatics 9: 299-306

Larsson MC, Hansson BS (1998). Receptor Neuron Responses to Potential Sex Pheremone Components in the Caddisfly Rhyacophila nubile (Trichoptera: Rhyacophilidae). Journal of Insect Physiology 44: 189-196

Leschen RAB, Buckley TR, Harman HM, Shulmeister J (2008). Determining the origin and age of the Westland beech (Nothofagus) gap, New Zealand, using fungus beetle genetics. Molecular Ecology 17: 1256-1276

Lehrian S, Pauls SU, Haase p (2009). Contrasting patterns of population structure in the montane caddisflies Hydropsyche tenuis and Drusus discolor in the Central European highlands. Freshwater Biology 54: 283-295

Lehrian S, Pauls SU, Haase P (2010). Genetic structure of an autumn-emerging caddisfly with inherently low dispersal capacity and insights into its phylogeography. Journal of the North American Benthological Society 29: 1100-1118

Librado P, Rozas J (2009). DnaSP v5: A software for comprehensive analysis of DNA polymorphism data. Bioinformatics 25: 1451-1452

Lloyd BD (2003) a. Intraspecific Phylogeny of the New Zealand Short-Tailed Bat Mystacina tuberculata Inferred from Multiple Mitochondrial Gene Sequences. Systematic Biology 52: 460-476

Lloyd BD (2003) $b$. The demographic history of the New Zealand short-tailed bat Mystacina tuberculata inferred from modified control region sequences. Molecular Ecology 12: 18951911 
Lowe DJ Shane PAR, Alloway BV, Newnham RM (2008). Fingerprints and age models for widespread New Zealand tephra marker beds eruption since 30,000 years ago: a framework for NZ-INTIMATE. Quaternary Science Reviews 27: 95-126

Maingon RDC, Ward RD, Hamilton JGC, Noyes HA, Souza N, Kemp SJ, Watts PC (2003). Genetic identification of two sibling species of Lutzomyia longipalpis (Diptera: Psychodidae) that produce distinct male sex pheromones in Sobral, Ceará State, Brazil. Molecular Ecology 12: 1879-1894

Markgraf V, McGlone M, Hope G (1995). Neogene paleoenvironmental and paleoclimactic change in southern temperate ecosystems - a southern perspective. TRENDS in Ecology and Evolution 10: $143-147$

Marshall DC, Hill KBR, Fontaine KM, Buckley TR, Simon C (2009). Glacial refugia in a maritime temperate climate: Cicada (Kikihia subalpine) mtDNA phylogeography in New Zealand. Molecular Ecology 18: 1995-2009

Marske KA, Leschen RAB, Barker GM, Buckley TR (2009). Phylogeography and ecological niche modelling implicate coastal refugia and trans-alpine dispersal of a New Zealand fungus beetle. Molecular Ecology 18: 5126-5142

McDowall RM (1996). Volcanism and freshwater fish biogeography in the northeastern North Island of New Zealand 23: 139-148

McDowall RM (2010). Historical and ecological context, pattern and process, in the derivation of New Zealand's freshwater fish fauna. New Zealand Journal of Ecology 34: 185-194

McGlone (1988). New Zealand. In: Huntley B, Webb T (editors) Vegetation history, pp 557-599. Kluwer Academic Publishers, Dordrecht.

McGlone MS, Salinger MJ, Moar NT (1993). Paleovegetation studies of New Zealand's climate since the last glacial maximum. In: Wright HG, Kutzbach JE, Webb T, Ruddiman WF, Street-Perrot JA, Bartlein PJ (editors) Global climates since the last glacial maximum, pp 294-317. University of Minnesota Press, MN,

McGlone MS, Duncan RP, Heenan PB (2001). Endemism, species selection and the origin and distribution of the vascular plant flora of New Zealand. Journal of Biogeography 28: 199-216

Morgan-Richards M, Trewick SA, Stringer IAN (2010). Geographic parthenogenesis and the common tea-tree stick insect of New Zealand. Molecular Ecology 19: 1227-1238

Naish TR (2005). Preface: New Zealand's shallow-marine record of Pliocene-Pleistocene global sealevel and climate change. Journal of the Royal Society of New Zealand 35: 1-8

Nakano T, Spencer HG (2007). Simultaneous polyphenism and cryptic species in an intertidal limpet from New Zealand. Molecular Phylogenetics and Evolution 45: 470-479

Neiman M, Lively CM (2004). Pleistocene glaciations is implicated in the phylogeographical structure of Potamopyrgus antipodarum, a New Zealand snail. Molecular Ecology 13: 3085-3098

Neumann D (1976). Adaptations of chironomids to intertidal environments. Annual Review of Entomology 21: 1099-1121 
Nickel JE (2009).The diversity of Hippocampus abdominalis in New Zealand. MSc thesis, University of Waikato Research Commons

Novotny V, Basset Y, Miller SE, Weiblens, Bremer B, Cizek, Drozd P (2002). Low host specificity of herbivorous insects in a tropical forest. Nature 416: 841-844

O'Neill SB, Buckley TR, Jewell TR, Ritchie PA (2009). Phylogeographic history of the New Zealand stick insect Niveaphasma annulata (Phasmatodea) estimated from mitochondrial and nuclear loci. Molecular Phylogenetics and Evolution 53: 523-536

Papadopoulou A, Anastasiou I, Volger AP (2010). Revisiting the Insect Mitochondrial Molecular Clock: The Mid-Aegean Trench Calibration. Molecular Biology and Evolution 27:1659-1672

Pauls SU, Lumbsch T, Haase P (2006). Phylogeography of the montane caddisfly Drusus discolor: evidence for multiple refugia and periglacial survival. Molecular Ecology 15: 1253-2169

Peterson I, Masters Z, Hildrew AG, Ormerod SJ (2004). Dispersal of adult aquatic insects into catchments of differing land use. Journal of Applied Ecology 41: 934-950

Peterson I, Winterbottom JH, Orton S, Friberg N, Hildrew AG, Spiers DC, Gurney WSC (1999). Emergence and lateral dispersal of adult Plecoptera and Trichoptera from Broadstone Stream, U.K. Freshwater Biology 42: 401-416

Posada D, Crandall KA (1998). MODELTEST: testing the model of DNA substitution. Bioinformatics 14: $817-818$

Pillans B (1991). New Zealand Quaternary Stratigraphy: an Overview. Quaternary Science Reviews 10: $405-418$

Previšić A, Walton C, Kučinić M, Mitrikeski PT, Kerovec M (2009). Pleistocene divergence of Dinaric Drusus endemics (Trichoptera, Limnephilidae) in multiple microrefugia within the Balkan Peninsula. Molecular Ecology 18: 634-647

Riek E.F. (1970). Trichoptera. In CSIRO “Insects of Australia”.Melbourne University Press, Melbourne.

Riek E.F. (1976). The marine caddisfly family Chathamiidae (Trichoptera).Journal of the Australian Entomological Society 15: 405-419

Raunio J, Paasivirta L, Brodin Y (2009). Marine midge Telmatogeton japonicus Tokunaga (Diptera: Chironomidae) exploiting brackish water in Finland. Aquatic invasions 4: 405-408

Ronquist F, Huelsenbeck JP (2003). MrBayes 3: Bayesian phylogenetic inference under mixed models. Bioinformatics 19: 1572-1574

Ross RM, Hogg ID, Pilditch CA, Lundquist CJ (2009). Phylogeography of New Zealand's coastal benthos. New Zealand Journal of Marine and Freshwater Research 43: 1009-1027

Schärer MT, Epler JH (2007). Long-range dispersal possibilities via sea turtle - a case for Clunio and Pontomyia (Diptera: Chironomidae) in Puerto Rico. Entomological News 118: 273-277 
Schultheis AS, Huges JM (2005). Spatial patterns of genetic structure among populations of a stonecased caddis (Trichoptera: Tasimiidae) in south-east Queensland, Australia. Freshwater Biology 50: $2002-1010$

Shakun JD, Carlson AE (2010). A global perspective on Last Glacial Maximum to Holocene climate chane. Quaternary Science Reviews 29: 1801-1816

Shepherd LD, Perrie LR, Brownsey PJ (2007). Fire and ice: volcanic and glacial impacts on the phylogoeraphy of the New Zealand forest fern Asplenium hookerianum. Molecular Ecology 16: 4536-4549

Smith PJ, Collier (2001). Allozyme diversity and population genetic structure of the caddisfly Orthopsyche fimbriata and the mayfly Acanthoplebia cruentata in New Zealand streams. Freshwater Biology 46: 795-805

Smith PJ, McVeagh SM, Collier KJ (2006) a. Genetic diversity and historical population structure in the New Zealand mayfly Acanthophlebia cruentata 51: 12-24

Smith PJ, McVeagh SM, Collier KJ (2006) b. Population-genetic structure in the New Zealand caddisfly Orthopsyche fimbriata revealed with mitochondrial DNA. New Zealand Journal of Marine and Freshwater Research 40: 141-148

Smith PJ, Smith BJ (2009). Small-scale population-genetic differentiation in the New Zealand caddisfly Orthopsyche fimbriata and the crayfish Paranephrops planifrons. New Zealand Journal of Marine and Freshwater Research 43: 723-734

Soong K, Chen GF, Cao JR (1999). Life History Studies of the Flightless Marine Midges Pontomyia spp. (Diptera: Chironomidae). Zoologial Studies 38: 466-473

Sponer R, Roy MS (2002). Phylogeographic analysis of the brooding brittle star Amphipholis squamata (Echinodermata) along the coast of New Zealand high cryptic genetic variation and cryptic dispersal potential. Evolution 56: 1954-1967

Stevens MI, Hogg ID (2004). Population genetic structure of New Zealand's endemic coropiid amphipods: evidence for allopatric speciation. Biological Journal of the Linnean Society 81: $119-133$

Sutherland DL, Hogg ID, Waas JR (2010). Phylogeography and species discrimination in the Paracalliope fluviatilis species complex (Crustacea: Amphipoda): can morphologically similar heterospecifics identify compatible mates? Biological Journal of the Linnean Society 99: 196205

Suggate RP (1990). Late Pliocene and Quaternary Glaciations of New Zealand. Quaternary Science Reviews 9: 175-197

Suggate RP, Stevens GR, Te Punga MT (1978). The Geology of New Zealand. Government Printer, Wellington, New Zealand.

Suggate RP, Almond PC (2005). The Last Glacial Maximum in western South Island, New Zealand, New Zealand: implications for the global LGM and MIS 2. Quaternary Science Reviews 24: 1923-1940 
Swofford DL (1999). PAUP : Phylogenetic Analysis Using Parsimony (* and other methods), Version 4. Sinauer Associates, Sunderland, MA.

Tajima F (1989). Statistical method for testing the neutral mutation hypothesis by DNA polymorphism.Genetics 123: 585-595

Taylor RB, Cole RG (1994).Mobile epifauna on subtidal brown seaweeds in northeastern New Zealand. Marine Ecology Progress Series 115: 271-282

Taylor R.B., Steinberg P.D. (2005). Host use by Australasian seaweed mesograzers in relation to feeding preferences of larger grazers, Appendix D. Ecology 86: 2955-2967

Trewick SA, Goldberg J, Morgan-Richards M (2005). Fewer species of Argosarchus and Clitarchus stick insects (Phasmida, Phasmatidae): evidence from nuclear and mitochondrial DNA sequence data. Zoologica Scripta 34: 483-491

Veale A (2007). Phylogeography of two intertidal benthic marine invertebrates around New Zealand: the waratah anemone (Actina tenebrosa) and the snakeskin chiton (Sypharochiton pelliserpentis). Unpublished MSc thesis, University of Auckland, Auckland, New Zealand. 147 p.

Wallis GP, Judge KF, Bland J, Waters JM, Berra TM (2001). Genetic diversity in New Zealand Galaxias vulgaris sensu lato (Teleostei: Osmeriformes: Galaxiidae): a test of a biogeographic hypothesis. Journal of Biogeography 28: 59-67

Ward J.B. (1994). The New Zealand Marine Caddisflies (Trichoptera).The Weta 17: 18-20

Ward J.B. (1995). Nine new species of New Zealand caddis (Trichoptera). New Zealand Journal of Zoology 22: 91-103

Ward JB, Henderson IM, Patrick BH, Norrie PH (1996). Seasonality, sex ratios and arrival pattern of some New Zealand caddis (Trichoptera) to light-traps. Aquatic Insects 18: 157-174

Waters JM (2008). Driven by the West Wind Drift? A synthesis of southern temperate marine biogeography, with new directions for dispersalism. Journal of Biogeography 35: 417-427

Waters JM, Craw (2008). Evolution and biogeography of New Zealand's longjaw galaxiids (Osmeriformes: Galaxiidae): the genetic effects of glaciations and mountain building. Freshwater Biology 53: 521-534

Waters JM, Roy MS (2004). Phylogeography of a high-dispersal New Zealand sea-star: does upwelling block gene-flow? Molecular Ecology 13: 2797-2806

Waters JM, Rowe DL, Apte S, King TM, Wallis GP, Anderson L, Norris RJ, Craw D, Burridge CP (2007). Geological Dates and Molecular Rates: Rapid Divergence of Rivers and Their Biotas. Systematic Biology 56: 271-282

Watts PC, Hamilton JGC, Ward RD, Noyes HA, Souza NA, Kemp SJ, Feliciangeli MD, Brazil R, Maingon (2005). Male sex pheromones and the phylogeographic structure of the Lutzomyia longipalpis species complex (Diptera: Psychodidae) from Brazil and Venezuela. American Journal of Tropical Medicine and Hygiene 73: 734-743 
Wilson CJN (1993). Stratigraphy, chronology, styles and dynamics of late Quaternary eruptions from Taupo volcano, New Zealand. Philosophical Transactions of the Royal Society of London, Series A 343: 205-306.

Wilson CJN, Walker GPL (1985).The Taupo eruption, New Zealand. I. General aspects. Philospophical Transactions of the Royal Society of London, Series A 314: 199-228

Wilson CJN (2001). The 26.5 ka Oruanui eruption, New Zealand: an introduction and overview. Journal of Volcanology and Geothermal Research 112: 133-174

Winterbourn MJ, Anderson NH (1980). The life history of Philanisus plebeius Walker (Trichoptera: Chathamiidae), a caddisfly whose eggs were found in a starfish. Ecological Entomology 5: 293304

Wilcock HR, Hildrew AG, Nichols RA (2001). Genetic differentiation of a European caddisfly: past and present gene flow among fragmented larval habitats. Molecular Ecology 10: 1821-1834

Wilcock HR, Nichols RA, Hildrew AG (2003). Genetic population structure and neighbourhood population size estimates of the caddisfly Plectrocnemia conspersa. Freshwater Biology 48: $1813-1824$

Wood JR, Resh VR (1984). Demonstration of sex pheromones in caddisflies (Trichoptera). Journal of Chemical Ecology 10: 171-175

Worthy TH, Holdaway RN (2002). The Lost World of the Moa: Prehistoric Life of New Zealand. Indiana University Press, Bloomington, Indiana. 


\section{Chapter Three: Phylogeny of the Chathamiidae and origins of the species Hydrobiosis lindsayi and Oecetis chathamensis (Insecta: Trichoptera) with regard to the formation of the Kermadec and Chatham Islands.}

\subsection{Introduction:}

Aside from the main islands, New Zealand biogeographic region consists of several groups of isolated oceanic islands as far afield as the Kermadec, Chatham, Auckland, Antipodes and Campbell Islands, comprising an area spanning over $20^{\circ}$ of latitude from the subantarctic to the subtropics. All these groups share close biological links with New Zealand and to each other in spite of being as far from the main islands as $1,000 \mathrm{~km}$. However, although the biogeographic understanding of New Zealand's mainland is now particularly well documented, New Zealand's oceanic islands are usually ignored in contemporary molecular studies (Heenan et al. 2010).

The Chathamiidae are an unusual family of caddisflies that breed in the marine intertidal zone, and are one of a handful of invertebrate families that are often thought of as endemic to New Zealand (Gibbs 2006). Although all five species and two genera are found in New Zealand, uniquely the most common species Philanisus plebeius has been found to be resident in New South Wales Australia since 1904 (Hudson 1904, Riek 1970). This is currently the only known New Zealand caddisfly species that is not fully endemic (Collier 1993), although the Australian population is almost certainly a recent dispersal event from New Zealand within the last few thousand years (Refer to Chapter Two of thesis). The family also has the ecological requirements of a marine invertebrate species and therefore does not require any established terrestrial ecology to flourish, yet can disperse as an airbourne winged phase at adulthood. It therefore follows that the Chathamiidae represents a group of evolutionary and biogeographic interest.

There are five established species all having been described in detail by Riek (1976) and Ward (1994, 1995) distributed throughout New Zealand (see Fig 3.1). The abundant and well-studied 
Philanisus plebeius is found throughout New Zealand and New South Wales, P. mataua is restricted to a few sites in the upper North Island including the three Kings Islands, P. fasciatus to the Kermadec Islands, Chathamia intergripennis to the upper North Island, and C. brevipennis to the Chatham Islands. The island endemic species (C. brevipennis and $P$. fasciatus) have only been collected in the largest of the islands in their archipelagos (Chatham Island and Raoul Island respectively) and it is unknown whether they are more widely distributed.

Only the common Chathamiid species Philanisus plebeius and Chathamia integripennis have been included in any phylogenetic studies to date; although the family is shown to be genetically distinct and monophyly is supported (Kjer et al. 2001, 2002, Hogg et al. 2009, Johanson et al. 2009, Johanson \& Malm 2010). In spite of both species being placed in separate genera the genetic distance between the two has been shown to be surprisingly small (a base pair difference of $3.2 \%$ for COI, Hogg et al. 2009), a distance for caddisflies typically found within genera and smaller than found even within some established species (Hogg et al. 2009, Pauls et al. 2009, Lehrian et al. 2010, Zhou et al. 2010). In addition the monophyly of Chathamia is unclear, with C. integripennis placed in the same genus as the initially described $C$. brevipennis based on 'similarity' with no typical 'Chathamia' features having been discussed (Riek 1976). It is indicated that the taxonomy of the family may need revision, and as a result any new genetic information should provide important data for resolving the taxonomy of this group.

Both the endemicity status of the family as well as the small number of species, easily allows for a complete phylogenetic analysis. Also importantly the group's archipelagic distribution would mean a phylogeny would also have a significant biogeographic application. $P$. fasciatus for example is likely to have begun diverging since its isolation on the Kermadec Islands. However the island chain is volcanic and has had a dynamic history making a prior estimation of the age of the group, and thus P. fasciatus, almost impossible. Although the major islands are estimated a few tens of thousands of years old, the age of continuous land in the island chain itself remains largely unknown (Smith $e t$ al. 2006). The Chatham Island group has been relatively stable much longer since the early Pleistocene 2Ma and perhaps even earlier (Campbell 1998, Paterson et al. 2006, Campbell et al. 2006, 
Campbell \& Hutching 2007, Campbell et al. 2008), a characteristic that may be reflected by the relatively divergent morphology of $C$. brevipennis, including brachyptery (wing reduction) in the adults. It is plausible that $C$. brevipennis has been resident on the Chatham Islands shortly since emergence.

Aside from C. brevipennis at least four to five other species of Trichoptera are found on the Chatham Islands. Hydrobiosis lindsayi (Hydrobiosidae) and Oecetis chathamensis (Leptoceridae) are endemic to Chatham Island, although very similar to related species in New Zealand (Tillyard 1925). Two 'micro-caddisfly' species (Hydroptilidae), Oxyethira albiceps and Paraoxyethira hendersonsi also inhabit the Chathams; however are minute, adaptable and extremely common species also found throughout New Zealand and its subantarctic islands (Wise 1964, 1972, Neboiss 1986, Marris 2000). A final species, Hudsenoma species ' $\mathrm{X}$ ' (Leptoceridae), has been collected on at least two occasions, however remains undescribed as a species. These species present further opportunity for further exploration of caddisfly colonisation and evolution between Chatham Islands and New Zealand and serve as a comparison for any analysis of $C$. brevipennis.

\subsubsection{The Chatham Islands}

The Chatham Islands are of particular interest due to the large size of the islands $\left(996 \mathrm{~km}^{2}\right)$ as well as their isolation (roughly $800 \mathrm{~km}$ East of New Zealand). The islands are the only emergent region of the extensive continental Chatham rise east of New Zealand, and are known to have once formed part of continental Gondwana; clearly demonstrated for example by dinosaur fossils from the Cretaceous (Stilwell et al. 2006, Campbell \& Hutching 2007). Ancient vicariance has been hypothesised to explain the origin of the Chatham biota as having a Gondwanan origin (Craw 1988), however the area is now known have remained underwater since the submergence of Zealandia in the Cenozoic (Wood et al. 1989, Campbell et al. 1994, Trewick et al. 2007). The geological foundations of most of the modern Island group itself only formed from Pliocene-Miocene intra-plate basaltic volcanism dating roughly 6-4 Ma. Despite this, there is evidence suggesting that the region 
nevertheless remained submerged and the modern islands only finally emerged due to uplift in the Pleistocene, roughly 2 Ma (Campbell 1998, Paterson et al. 2006, Campbell et al. 2006, 2008, Campbell \& Hutching 2007). Estimating the age of the islands is additionally complicated by the known existence of an emergent volcano now forming Mangere Island (the 'Mangere Volcano') 6-4 $\mathrm{Ma}$, and the modern Island has remains of fossils and a freshwater lake from this period (Campbell \& Hutching 2007). However geological evidence indicates the Volcano fully submerged in the mid Pliocene, and there is believed to have been no land in the Chatham region 4-2 Ma. Any of the old 'Mangere biota' is generally assumed long extinct.

The modern Islands today comprises a single large landmass (Chatham Island) and several smaller islands and islets; however during lower sea levels during Pleistocene ice ages the archipelago would have been considerably larger and fully interconnected (Hay et al. 1970). The biota of the Chatham Islands is characterised by a high level of endemicity, although is believed entirely of recent New Zealand origin via oceanic dispersal. The endemic biota has been thoroughly investigated through a large number of molecular studies which almost universally point to young Pleistocene origins; in insects (Trewick, Arensburger et al. 2004, Chinn \& Gemmell 2004, Trewick et al. 2005, Nolan et al. 2007, Marshall et al. 2008), freshwater crustaceans (Stevens \& Hogg 2004, McGaughran et al. 2006), Plants (Wagstaff \& Garnock-Jones 1998, Heenan et al. 2010), Spiders (Vink \& Paterson 2003) Galaxiid fish (Waters \& McDowall 2005) and Birds (Trewick 1997, Boon et al. 2000, Kennedy et al. 2000, 2001, Chambers et al. 2001, Miller \& Lambert 2006, Banks \& Paterson 2007). However this general pattern is not always consistent; Pliocene-Micoene ages up to 6 Ma have been inferred in some unusual cases; Geodorcus stag beetles (Trewick 2000), Skinks (Liggins et al. 2008) and at least four plant species (Heenan et al. 2010). Although in the minority, such studies may therefore potentially indicate a link between the modern 'Chatham' and the old 'Mangere' biotas (Heenan et al. 2010). 


\subsubsection{The Kermadec Islands}

The Kermadecs comprise a widely separated chain of six islands, all the peaks of large submarine stratovolcanoes $800-1,100 \mathrm{~km}$ North-East of New Zealand, terminating with the northernmost Raoul Island, roughly $900 \mathrm{~km}$ south of Tonga. Much smaller than the Chatham Islands, the island group only comprises a total of $33 \mathrm{~km}^{2}$, most of which is comprised of Raoul $\left(29.32 \mathrm{~km}^{2}\right)$ and Macauley $\left(3 \mathrm{~km}^{2}\right)$ Islands which also contain most of the biodiversity. Raoul volcano itself is highly active with a complex stratigraphy dating back roughly a million years; however most of the geology indicates submarine formation (such as the old boat cove pillow lavas from 0.6-1.4 Ma). By contrast the modern dacitic caldera dates only from the past $3.7 \mathrm{ka}$ and an age as young as $2 \mathrm{ka}$ has been suggested for the emergent island itself (Brothers \& Searle 1970, Kaplin 1981, Smith et al. 2006, 2010). The offshore submarine Denham caldera, significantly larger than the emergent Raoul caldera, has a similar age (2.2 ka Worthington et al. 1999).

The other main island; the smaller and currently inactive Macauley over $100 \mathrm{~km}$ to the South-West of Raoul, is known to have been considerably larger in the past until a major eruptive and caldera collapse event dated 6,310 years ago (producing the sandy bay tephra, SBT), prior to which it apparently approached or even exceeded modern Raoul in size (Brothers \& Martin 1970, Lloyd et al. 1996, Smith et al. 2003 a). Today the caldera remains almost entirely submerged, excepting the small island itself. Curtis Island is the only other island aside from Raoul still showing residual activity, although the island is small, eroded and evidently becoming dormant (Smith et al. 1988). None of the other smaller, southerly islands (Cheeseman Island, L'Esperance rock, and L'Havre rock - only exposed during low tide) have been studied nearly as extensively and their ages are unknown, although are dormant and relatively eroded (Smith et al. 2006). Due to the dynamic nature of the islands it is currently very difficult estimating the age of the islands as emergent land from geology alone.

The island group does contain a number of endemic plant and animal taxa including intertidal and terrestrial plants, birds and invertebrates, although diversity is low and most species are shared 
with Tonga or New Zealand (Dugdale 1973, Watt 1975, Arensburger et al. 2004, Barkla et al. 2010). Molecular analysis of the endemic Kermadec pohutukawa (Metrosideros kermadecensis) suggests a New Zealand dispersal origin dating into the Pleistocene as much as 0.5-1 Ma before present (Wright et al. 2000, 2003). Molecular studies of Kermadec cicadas (Kikihia cutora exulis) show extremely close relationships to relatives in New Zealand, although molecular distances estimate a similar Pleistocene origin of $0.55 \pm 0.16 \mathrm{Ma}$ (Arensburger et al. 2004). From biological evidence it is indicated that there has been habitable land in the region for as much as $0.5 \mathrm{Ma}$, although much more molecular information is currently needed.

\subsubsection{Aims}

This chapter aims to use DNA sequences to construct a phylogeny of the Chathamiidae, and by using a rough molecular clock, to understand the evolution of marine caddisfly species in the Kermadec and Chatham Islands. These dates can then also be used as supportive information in estimations of the island groups themselves. The evolutionary origin of other caddisfly species from the Chatham Islands will also be investigated for comparison with the species $C$. brevipennis.

\subsection{Materials and Methods}

\subsubsection{Sample collection}

Samples of $P$. plebeius and $C$. integripennis were collected from around New Zealand and Australia from November 2008 to February 2010 (see Chapter two of thesis). Philanisus fasciatus were collected by Karen Baird from Raoul Island in May 2010. Specimens of C. brevipennis, Hydrobiosisis lindsayi and Oecetis chathamensis were collected from localities in Chatham Island. Samples of Oecetis unicolor collected from mainland New Zealand was also used for outgroup analysis. Methodology of collection was largely that as described in Chapter two and included the 
collection of larvae, adults and pupae. Adults were collected from near appropriate habitat either being coasts, lakes or streams; either by light-trapping or collected by hand when possible. All larvae or pupae were collected by searching manually through substrate of the rocky intertidal or small running streams, for marine or freshwater species respectively. No samples of $P$. mataua were successfully collected, however a single museum specimen was generously provided for this study. Collection and specimen details are listed in Fig 3.1.

\subsubsection{DNA sequencing and alignment}

DNA was extracted using a standard phenol-chloroform methodology (refer to Chapter two of thesis), using leg material from a number of specimens (3-5 individuals) of Oecetis chathamensis, $O$. unicolor, Hydrobiosis lindsayi, Chathamia brevipennis, C. integripennis, Philanisus plebeius, and $P$. fasciatus. For $P$. plebeius only 3 individuals were used; one to represent each of the three genetic haplogroups identified in Chapter Two. Also included was an unidentified larva from near Sydney, originally identified as P. plebeius.

A 618 bp fragment of the mitochondrial gene cytochrome oxdidase I (COI) was amplified using the primers HCO2198 and LCO1490 (Folmer et al. 1994). Additionally for each of the Chathamiidae species (except $P$. mataua) and each of the three haplogroups of P.plebeius; a fragment of the mitochondrial gene 16S was amplified using the primers 16SBRH and 16SARL (Palumbi et al. 1991). In the case of the older P. mataua specimen, LCO1490 was paired with the primer ChatP12r (new to this study), and was amplified and sequenced twice to counter for possible mis-priming. All primers are listed in Table 3.2. The concentrations and parameters for the PCR template, thermocycler, purification and sequencing have been presented in Chapter Two. All DNA sequencing used one primer only; HCO2198 for COI and 16SBRH for 16S. Also used were a large number of sequences from Genbank from a number of related studies. All sequences are listed with specimen details in Table. 3.1. 
Chromatograms were visualised using Chromas software V. 145 (Technelysium Pty Ltd; http://www.technelysium.com.http://au/chromas.html). All sequences were loaded into the Clustal X algorithm in MEGA 4.0 (Kumar et al. 2007, 2008). Both COI and 16S were aligned using default parameters, with finer scale editing of $16 \mathrm{~S}$ by eye.

\subsubsection{Genetic analysis and phylogenetic reconstruction}

The COI dataset was explored and had sequence statistics determined using the MEGA data explorer tool and DNAsp v 5 (Librado \& Rozas 2009). Several separate datasets were used for phylogenetic reconstruction. A dataset of COI for the Chathamiidae was used using all obtained sequences of $P$. fasciatus, $C$. brevipennis and $C$. integripennis with a single sequence used from each of the three haplogroups of P. plebeius identified in Chapter Two. A smaller dataset using 16S data was analysed separately. For outgroup taxa, sequences of Olinga feredayi and Zelolessica cheira were used to represent the Conoesucidae and Helicophidae respectively; two of the closest families to the Chathamiidae (Kjer et al. 2001, 2002, Johanson \& Keijsner 2008, Johanson et al. 2009, Johanson \& Malm 2010, also refer to Chapter four of thesis).

Additionally another dataset comprised entirely of COI was used to explore the origin of the Chatham Island species Hydrobiosis lindsayi and the phylogeny of the endemic New Zealand genus Hydrobiosis as a whole, with all sequences other than $H$. lindsayi imported from Genbank, constituting over half of all described species (13 out of 24). Additionally another New Zealand genus, Edpercivalia, was also included as a possible subtaxon of Hydrobiosis as evidenced in another study (Hogg et al. 2009). Only two species of Edpercivalia were used (out of 12 described species), however if nested within Hydrobiosis the genus likely forms a monophyletic crown group. For outgroups, representatives of related Hydrobiosid caddisflies with the Hydrobiosinae were included, using a genetic data from every genus sequenced so far available online. The species Apsilochorema hwangi (subfamily Apsilochoreminae) was used as a basal taxon to root the tree. 
All Oecetis sequences formed yet another, smaller dataset. The only other New Zealand species of Oecetis; O. iti, was not included, however is known only from few sites in the central South Island and the upper North Island and is unlikely to be important in the ancestry of $O$. chathamensis (contrast to $O$. unicolor which is widespread). No close relatives to serve as approptiate outgroups were obtainable for this analysis (which would likely be closely related species from Australia). Due to only two taxa being used, the Oecetis dataset was left unrooted, and explored using only a simple neighbour-joining analysis in MEGA (10,000 bootstrap replicates, default assumptions: maximum composite likelihood, homogenous pattern among lineages, uniform rate among sites).

For the remaining datasets, phylogenetic analyses were performed using the software packages MrBayes 3.1 (Heulsenbeck \& Ronquist 2001, Ronquist \& Huelsenbeck 2003) and PAUP* 4.0 (Swofford 1999).The program MODELTEST 3.7 (Posada \& Crandall 1998) was implemented through PAUP* to identify the most likely suitable evolutionary model using the Akiake information (AIC), selecting a GTR $+\mathrm{I}+\mathrm{G}$ modelfor both COI datasets (Chathamiidae and Hydrobiosidae) and selecting a GTR+I model for 16s.

Maximum parsimony (MP, Farris 1970) and Maximum Likelihood (ML, Felsenstein 1981) analyses were estimated using PAUP* on the COI dataset for the Chathamiidae. Maximum parsimony was performed using a heuristic search model, and bootstrapped using 10,000 replicates. Maximum likelihood was run using the model selected by MODELTEST and run under a heuristic search criterion using 10,000 replicates for bootstrap support.

Bayesian analyses were implemented in MrBayes 3.1, again using the closest model possible as suggested by MODELTEST, and run for all datasets. For each dataset one cold and three heated Markov chains were run for a total of either $10,000,000$ generations sampled every 1,000 to obtain a total of 1,000 trees (for both Chathamiidae sets) or 20,000,000 generations for a sample of 2,000 trees (for the Hydrobiosidae). The first $25 \%$ of trees were discarded as a burn-in phase, with the remaining trees used to estimate the posterior probabilities. 


\subsubsection{Estimating divergences and molecular clock}

In order to infer the ages of the species a molecular clock was attempted on the dataset. The prospect by which an independent clock can be used in this study is limited however. Helicophidae from the purbeck beds of England (154.8-137.2 Ma, Sukatsheva \& Jarzembowski 2001), and two fossil taxa with affinites to the Calocidae, Helicophidae and Conoesucidae have been identified from Baltic Amber (85-74 Ma, Botosaneanu \& Wichard 1983), although one has since been ascribed to the Northern family Sericostomatidae (Wietchat \& Wichard 1998), neither of which therefore suitable as reliable estimates for a recent common ancestor. Excepting perhaps the probable Pleistocene age of the Chatham Islands, no fossil or geological dates can be used here with any confidence.

A divergence rate was estimated using two strict molecular clocks used from Brower 1994 (2.3\% per Ma) and Papadopoulou et al. 2010 (3.54 / 2.69\% for COI / COI+16s). Pairwise distances used for calibration were estimated in MEGA, using corrected (between mean) group distances, with each species analysed with its assumed nearest sister taxon as inferred by estimated phylogeny and/or genetic distance. The species Philanisus fasciatus and Chathamia integripennis are assumed to form sister taxa based on molecular distance. Also as the phylogeny of Hydrobiosis remained largely unresolved (see results, fig 3.8), distances were estimated between $H$. lindsayi and the mean divergence from the closest remaining 'Umbripennis' Hydrobiosis species (H. copis, H. budgei, H. umbripennis, H. parumbripennis, H. johnsi, H. styracine and H. falcis), Standard error was calculated with in MEGA with 10,000 replicates with use of the Kimura-2 parameter model.

\subsection{Results}

\subsubsection{Sample collection}

Most target species were successfully collected from Chatham Island. Only larvae and pupae of Chathamia brevipennis were found, all from near Kaingaroa township in the North-West of the Island amongst coralline algae, in spite of repeated light trapping for adults in near Port Hutt, 
Waitangi and Owenga. No Hudsonema were collected from the island although a possible abandoned larval case was found in Awatotara creek, near the southern end of Chatham Island, indicating a breeding population, although this may have been of Oecetis chathamensis. Adults of $O$. chathamensis by contrast were common and easily collected in number throughout the island including from Te Whanga lagoon, lakes and streams. Hydrobiosis lindsayi were readily collectable as larvae, pupae and adults from or near any clean running stream. From the remainder of New Zealand samples of adult Oecetis unicolor, P. plebeius, P. fasciatus and C. integripennis were readily obtained, although no P. mataua were collected.

Also in addition, large numbers of the microcaddisfly genera Paraoxyethira and Oxyethira were collected from both New Zealand and Chatham Islands. However as the species on the Chathams are the same from New Zealand and other distant islands; an in-depth phylogeographic analysis would be needed for each species, which would be logistically difficult as Hydroptilid caddisflies are among the most common and ubiquitous insects in New Zealand. Whilst in the duration of this study it was eventually decided not to analyse these species.

\subsubsection{Sequences and sequence statistics}

The Philanisus mataua sequence had a number of sites shown in chromatograms with twin peaking, taken to be the presence of two mitochondrial sequences within the same individual. This species was thus analysed separately (see methods). The COI dataset for the Chathamiidae (omitting P. mataua and outgroups) constituted 618 base pairs, with 70 variable sites and 66 parsimony informative sites. The Hydrobiosidae dataset constituted 620 base pairs, which within Hydrobiosis and Edpercivalia alone 200 of which were variable and 158 parsimony informative. The Oecetis dataset was 633 base pairs, with 30 variable sites and 21 parsimony informative sites. The 16S dataset (only Chathamiidae) was 418 base pairs with 44 variable; however only 3 were parsimony informative - likely due to the extreme singular divergence of $C$. brevipennis for this gene (see Fig. 3.5). Nucleotide compositions were generally consistent across all lineages; $32.6-40.8 \% \mathrm{~T}, 13.8$ - 
$19.4 \% \mathrm{C}, 29.4-33.5 \% \mathrm{~A}, 11.8-17.4 \% \mathrm{G}$ for COI, and $40.40-40.6 \% \mathrm{~T}, 7.1-7.2 \% \mathrm{C}, 39.7-40.1 \% \mathrm{~A}$, 12.2-12.6 G\% for 16s. However the Chathamiidae were generally more A-T rich, and the Hydrobiosidae more G-C rich for COI.

Pairwise divergences from within groups and between groups means are shown in Tables 3.43.6 (also see Table 3.7 for Oecetis). Distance analysis alone strongly indicates a high divergence for C. brevipennis, and confirming separate species status for Oecetis chathamenis and Hydrobiosis lindsayi. High interspecific divergences (>1\%) are indicated for P. plebeius and O. unicolor, and little or no variation for C. brevipennis, P. fasciatus or H. lindsayi. Additionally no variation was found within 16s for Philanisus plebeius (not shown in figures).

\subsubsection{Phylogeny of the Chathamiidae}

Maximum likelihood, Maximum parsimony and Bayesian trees of COI \& $16 \mathrm{~S}$ data all Chathamiidae species, excepting P. mataua, are shown in figs 3.3-3.6. Monophyly of either genus was not supported. C. brevipennis was established as a relatively distant sister taxon to P. plebeius, $P$. fasciatus and $C$. integripennis which form a closely related monophyletic group (the 'Philanisid clade') strongly supported by both $16 \mathrm{~s}$ and COI data. Within the 'Philanisid' group relationships were unclear, although Bayesian analyses indicated a C. integripennis- $P$. fasciatus sister relationship for COI and a C.integripennis-P.plebeius sister relationship for $16 \mathrm{~s}$.

C. integripennis was the most widely sampled taxon (not including P. plebeius from Chapter Two) and displayed the most genetic variation (0.6\%). The 'Sydney Chathamiid', a larva previously assumed to be P. plebeius based on location is indicated unusually to be a $C$. integripennis occurring in Australia, closely related to one haplotype in particular from New Zealand ("05" - Hogg et al. 2009, 1 base pair difference). 


\subsubsection{Phylogenetic placement of Philanisus mataua}

The short sequence obtained from the single sample of $P$. mataua was highly ambiguous, and chromatograms consistently confirmed the presence of two separate mitochondrial sequences (the region was amplified and sequenced twice, and in both cases chromatograms showed the same results). Within the region of COI sequenced for P. mataua (418 base pairs), there were 20 variable sites within the Philanisid clade, 7 of which were heterogeneous for P. mataua. In addition no site changes were unique to this sequence; all variable sites fell within variation for either P. plebeius or C. integripennis. Uncorrected pairwise distances (not including ambiguous regions) were identical between the $P$. mataua sequence and either the 'Sydney Chathamiid' (see above) or a New Zealand $C$. integrippenis sequence ("05”) imported from Hogg et al. (2009), both indistinguishable at the COI region concerned (the two ultimately differ elsewhere however). 3 singleton sites (4 if P. fasicatus is excluded) unique to these $C$. integripennis sequences converged with heterogeneous base pair regions within the $P$. mataua sequence, indicating one sequence to match the $C$. integripennis haplotype.

If the phasing is assumed to be the same as with the C. integripennis sequence, then was possible to form a hypothetical counter-sequence ( $P$. mataua 'A' and 'B'; with 'A' identical to $C$. integripennis). The B sequence was found to fall within variation exhibited within P. plebeius, although divergent and unrelated to any known haplotype. Uncorrected divergence distances between P. mataua 'B' and P. plebeius ranged from $0.79-1.49 \%$, (only $0.79-0.99 \%$ to P. plebeius clade A). Neighbour-joining trees for the unmodified and modified P. mataua sequence/s and all available Philanisus data (including C. integripennis) are shown in Figs 3.9-3.10.

\subsubsection{Phylogeny of Hydrobiosis and Oecetis}

Oecetis chathamensis was found to be distinct from $O$. unicolor supporting separate species status (see Fig 3.7) However genetic diversity was considerably higher within O. unicolor (1.5\% vs 0.5), approaching levels found between species. The dataset of the Hydrobiosidae generally showed varying levels of Bayesian support. Edpercivalia was weakly suggested to be nested within 
Hydrobiosis sister to the species $H$. charadraea, however at the very least is indicated to form the sister taxon followed by the genus Costachorema. The inner phylogeny of Hydrobiosis itself was less clear although monophyly of the 'Umbripennis' group was well supported, with $H$. gollanis basal to the other species (including $H$. lindsayi), in turn shown to be closely related.

\subsubsection{Divergences and Age assumptions}

Mean corrected pairwise divergences for each taxon of interest with hypothesised divergence ages are shown in Table 3.6. Chathamia brevipennis is indicated to represent the oldest lineage analysed at 4.91-2.46 Ma in age, followed by at Hydrobiosis lindsayi at 4-2.1 Ma. The remainder of the Chathamiidae are indicated to have diverged more recently during the Pleistocene 1.39-0.56 Ma, the most recent split being with Chathamia integripennis and Philanisus fasciatus 0.92-0.34 Ma. Oecetis chathamensis and O. unicolor are suggested to have diverged 1.78-0.79 Ma. The molecular models had a high margin of error (using two clocks), however $C$. brevipennis was indicated to show largely congruent ages using each clock and gene (roughly 4 Ma), with the exception of the 3.59\% clock from Papadopoulou et al. (2010) for COI.

\subsection{Discussion}

\subsubsection{Phylogeny and taxonomy of the Chathamiidae}

As clearly shown by both COI and 16S data, both Chathamia and Philanisus are polyphletic taxa with the species $C$. integripennis nested within Philanisus (related to P. fasciatus in particular) together comprising a a 'Philanisid' clade. The only other species of Chathamia, C. brevipennis, by contrast formed a remote sister taxon to this grouping. This relationship is also supported by biogeographic inference as the northerly-distributed $C$. integripennis makes a poor candidate to be close to the ancestry of the Chatham Island $C$. brevipennis. As $C$. brevipennis is the type species of Chathamia, this can be easily resolved by transferring C. integripennis to Philanisus (creating the new 
species name Philanisus integripennis), rendering both genera monophyletic and leaving Chathamia monotypic and endemic to the Chatham Islands.

The high genetic distance between $C$. brevipennis and the remainder of the family also supports the retention of the genus Chathamia as distinct from Philanisus, although distances suggestive of subfamily status were not supported in agreement with Riek (1976). Any morphological features identified by Riek between Chathamia integripennis and C. brevipennis are considered to be analogous convergences, or alternatively plesiomorphic features (however this would indicate the species to have been the basal 'Philanisid' in regard to the probable singular evolution of 'Philanisus' features, which was never supported - the basal Philanisid was likely either P. plebeius or $P$. fasciatus). The extant representatives of the Chathamiidae are indicated to have begun radiation in the Pliocene to early Pleistocene (with $C$. brevipennis), with the Philanisid group diverging in the late Pleistocene, roughly 1 Ma.

Another significant result was the identification of a larval $C$. integripennis to be found in Sydney New South Wales. Possible error was accounted for as the specimen was re-extracted and sequenced again, confirming the result. This is the first time this species has been found outside of Northern New Zealand, and joins P. plebeius as the only New Zealand caddisfly species to be also found in Australia. The sample also being larval clearly demonstrates a breeding population (as opposed to a rare adult vagrant). However the sample was identified very close to one NZ haplotype (1 base pair difference) indicating a very recent origin or possibly a human introduction (however the NZ sequence was not from this study and the collection locality remains unknown). The singular pair difference is also congruent with that found between the New Zealand and Australian populations of Philanisus plebeius, (see Chapter Two) although sampling in this species was much more thorough.

Philanisus mataua raised the most issue with phylogenetic placement, with sequenced data showing two mitochondrial sequences. This was considered not to reflect degeneration due to the age of the sample (a 17 year old museum specimen) as the heterogenous sites occurred only in areas variable in Philanisus (including $C$. integripennis), and either represents contamination or 
heteroplasmy. The two P.mataua sequences were considerably different (7/20 variable 'Philanisid' sites differed between them). Naturally occurring and divergent heteroplasmic sequences are generally the result non-maternal mitochondrial transmission, or 'paternal leakage' (Lansman et al. 1983). In insects, paternal leakage of mitochondrial DNA has been documented in species of bee (Meusel \& Moritz 1993, Magnacca \& Brown 2010 a, b), Drosophila (Satta et al. 1988, Kondo et al. 1990, 1992, Matsuura et al. 1991, Sherengul et al. 2006), mosquitoes (Paduan \& Ribolla 2008), moths (Arunkumar et al. 2006) and cicadas (Fonataine et al. 2007).

If the two sequences represent heteroplasmy then $P$. mataua appears to represent a hybrid between $P$. plebeius and $C$. integripennis (see Figs $3.9 \& 3.10$ ). This is biogeographically plausible; $P$. mataua is rare and occurs sympatrically with both P. plebeius and C. integripennis over most of its distribution (in the upper North Island see fig 3.1). Natural intraspecific hybridisation is not well documented in Trichoptera although is evidenced to occur in a number of studies (Blahnik 1995, Leese 2004, Pauls 2004, Wells 2006, Pauls et al. 2009, 2010). Heteroplasmy is also more frequent in hybrids; it has been suggested that intra-specific hybridisation leads to frequent heteroplasmy as oocyte enzymes are less likely to recognise and counter unrelated mitochondria (Kondo et al. 1990, Kaneda et al. 1995, Kvist et al. 2003, Ballard et al. 2004). Heteroplasmy does not seem to be commonly inherited (Gyllensten 1991) indicating this sample would likely be a direct hybrid.

However even among intraspecific hybrids heteroplasmy is generally uncommon (Kondo et al. 1990, Gyllensten 1991); thus the likelihood of one sample to be heteroplasmic is unlikely. It is also is unclear what extent the morphology of $P$. mataua is intermediate between $C$. integripennis and $P$. plebeius; several morphological features are distinct to the species (Ward 1994, 1995). Additionally C. integripennis is not recorded from the Three Kings Islands; an apparent stronghold of P. mataua (5/12 of all collection records, and 8 of about 20 known specimens). It is perhaps more probable the sample is simply contaminated by $C$. integripennis DNA, made only more likely as most of the sample was used for DNA extraction. Cannibalism is known to occur in normally herbivorous caddisfly larvae (Mecom 1972, Wissinger et al. 1996, 2004) and is known in P. plebeius (Leader 1976), although it seems unlikely consumed material as a larva would transmit through to adulthood. 
Contamination is probably the most parsimonious explanation although new $P$. mataua sequences are necessary to confirm either hypothesis.

Overall the taxonomy of the family needs some revising. It is proposed that Chathamia integripennis be transferred to the genus Philanisus. This would leave Chathamia a monotypic Chatham Island taxon, and Philanisus comprising all of the four species found in mainland New Zealand, the Kermadecs and Australia. Additionally new molecular data should be collected for $P$. mataua in order to test for its phylogenetic status. It cannot be ignored that possible hybridisation and molecular introgression may have considerable implications inferring the phylogeny of the Chathamiidae, especially as only mitochondrial markers were used in this study and that heteroplasmy is indicated (Posada \& Crandall 2002, Sackton et al. 2003, Piganeau et al. 2004).

\subsubsection{Phylogenetic placement of Hydrobiosis lindsayi and Oecetis chathamensis}

The placement of Edpercivalia as a subtaxon of Hydrobiosis was not well supported in this study. Morphological data supports the close relationship of Edpercivalia and Hydrobiosis, although Edpercivalia shares a number of presumably pleisomorphic features with Costachorema and separate genus status seems likely (Ward et al. 2004). Separate species status of $H$. lindsayi was supported, as is the placement of H. lindsayi within the Umbripennis group of Hydrobiosis (Schmid 1989, Smith 1998). Molecular divergence suggests the divergence of $H$. lindsayi from the remaining Hydrobiosis 4-2.1Ma, not fully congruent with a Pleistocene date for the origin of the Chatham Islands.

Oecetis chathamensis was also supported as distinct from $O$. unicolor, supporting morphological differences such as 'turquoise' coloured larvae unique to the taxon (Champion \& Clayton 2004), both diverging 1.78-0.79 Ma. The younger age of O. chathamensis (Leptoceridae) contrast to H. lindsayi (Hydrobiosidae) is likely expected. Although the Hydrobiosidae is the most diverse caddisfly family in New Zealand (roughly half of described species), Hydrobiosids are apparently poor long-distance dispersers with all native genera entirely endemic and globally have a largely southern Gondwanan biogeography (Schmid 1989, de Moor \& Ivanov 2008), although two 
have dispersed from New Zealand and are endemic to the Auckland Islands (Wise 1976, Schmid 1989, Micheaux \&Leschen 2004). Leptocerids are by contrast among the most widespread of Trichoptera and are among the few families to commonly inhabit oceanic islands (e.g. Malicky 1992, Smithers 2000, Wells 2004). In addition O. chathamensis and O. unicolor closely resembles the species O. umbra from Tasmania, and the whole New Zealand lineage is likely a recent Australian dispersal (Neboiss 1979, Wells 2004).

\subsubsection{Philanisus fasciatus and the Kermadec Islands.}

P. fasicatus was shown to form a distinct taxon, although closely related to the species $P$. plebeius, P. mataua and C. integripennis (the 'Philanisid' clade). Nevertheless, the species is indicated by COI data to have diverged from $C$. integripennis between 0.34-0.92 Ma, well into the early to mid Pleistocene. The date compares with the only other molecular study of a Kermadec insect; that found for Kermadec cicadas (0.39-0.71 Ma, Arensburger et al. 2004). The lineage that constitutes the Kermadec pohutukawa (Metrosideros kermadecensis) is believed to have dispersed out of New Zealand 0.5-1 Ma, although includes a number of Pacific species as far north as Hawaii (the 'excelsa' lineage) and some gene flow between M. kermadecensis and the New Zealand M. excelsa has been indicated (Wright et al. 2000, 2001, Gardner et al. 2004). No other molecular studies have been undertaken including any of the endemic Kermadec fauna or flora with the exception of two species of limpet (Wood \& Gardner 2007), however this only discussed local connectivity and no molecular clock was used.

From the current genetic evidence however it can be proposed that there has been continuous land in the Kermadec region suitable for terrestrial inhabitation $>0.3 \mathrm{Ma}$ and possibly considerably longer, also supported by the general existence of other species and subspecies endemic to the Islands. Using geological records to estimate an age of the islands is difficult, as being the tops of active volcanoes they are likely to have had an ephemeral history having risen and fallen numerous times in the past. The two largest islands (Raoul and Macauley Islands) are both closely linked to massive, 
near-surfacing submarine calderas both representing recent eruptive collapse events. Macauley Island was likely over 10 times its current size before the SBT eruption 6 ka (Brothers \& Martin 1970, Lloyd et al. 1996, Smith et al. 2003 a), and even the comparatively large Raoul was probably more massive until the collapse of Denham caldera $2.2 \mathrm{ka}$ (Worthington et al. 1999). Such events would have had a catastrophic effect on the biodiversity; for example the eruption $2.2 \mathrm{Ka}$ on Denham caldera is estimated to be comparable in volume to the 1883 Krakatau eruption (Worthington et al. 1999), and the SBT eruption is possibly one of the largest eruptions in the entire Holocene (Latter et al. 1992, Lloyd et al. 1996). If recent Holocene ages of Raoul and Macauley islands is assumed it is probable that there must have been sufficient continuous land elsewhere in the region long enough for some unique biota to form.

As is known with Macauley (Brothers \& Martin 1970, Lloyd et al. 1996, Smith et al. 2003 a), some or even all of the smaller islands (and their volcano bodies) were likely once much larger prior to caldera collapse and erosion. All islands would have also been considerably more massive during lower sea levels in the Pleistocene as recently as the last glacial maximum ( $20 \mathrm{ka})$. In addition the Kermadec chain also constitutes at least 26 major volcanic centres comprising numbers of submarine volcanoes and seamounts, some (such as the Giggenbach volcano) are high enough to have formed islands over $50 \mathrm{~m}$ high during this period (Wright 1994, Ballace et al. 1999, Smith et al. 2003 b, Wright et al. 2006). Collapse and re-eruption is common in the Kermadec-Tonga arc (Ballance et al. 1999, Wright et al. 2008), and thus there have likely been a number of islands, now long submerged. As a result of these factors the emergent areas of the Kermadec region have likely been under a period of considerable flux.

Therefore in spite of a volatile history it seems plausible there has been continuous land suitable to support terrestrial animal and plant life in the Kermadec region since the early-mid Pleistocene 0.3-0.5 Ma and perhaps earlier. However the Kermadec biota can therefore probably be assumed to have undergone a series of historical 'island-hopping' episodes and repeatedly subjected to regular local extinctions or volcanic 'sterilisations' with the current restriction of most species to Raoul and Macauley Islands untypical. Species such as $P$. fasciatus being largely intertidal, and $M$. 
kermadecensis able to colonise fresh lava flows (Clarkson 1990), may have been better suited for prolonged survival in this environment. This may also explain why overall diversity in the islands is low, although many more molecular studies are still needed.

\subsubsection{Chathamia brevipennis, Oecetis chathamensis, Hydrobiosis lindsayi and the Chatham} Islands.

C. brevipennis was indicated conclusively by both COI and 16 s to be highly divergent from the remainder of the Chathamiidae and that Chathamia should be rendered a monotypic genus endemic to the island group (Chathamia integripennis being unrelated and nested within Philanisus). This may be significant as although endemicity in the Chatham Islands is high, levels only very rarely reach above the species or sub-species level (Emberson 1995, 1998 Heenan et al. 2010). For age estimates, Chathamia brevipennis diverged from the remaining Chathamiidae 2.46-4.91 Ma ago, supporting a Pliocene origin of the species. The genetic divergence ( 10\% for COI and $16 \mathrm{~s})$ and the age (>2.4 Ma) are among the highest found for any Chatham Island species. Additionally Hydrobiosis lindsayi was also indicated a possibly old taxon 4-2.1 Ma in age, although the lower estimates are congruent with geological records. Oecetis chathamensis was indicated conclusively to be a recent Pleistocene dispersal roughly $1 \mathrm{Ma}$ in age, typical of most Chatham species.

However these dates should perhaps be considered carefully, Brower's substitution rate in particular has been known to considerably overestimate probable divergence times in Lepidoptera (Gratton et al. 2008). However such rates invariably differ between lineages, and other subsequent studies on insects using independent clock models have inferred a wide variety of divergence rates (Papadopoulo et al. 2010). In addition strict models assume a constant rate of divergence; however rates are known to be non-linear, rapidly decreasing with age as nucleotide saturation and selection pressures begin to play an increasing role (Brown et al. 1979, 1982, Arbogast et al. 2002).

Relaxed molecular clocks allow rates to differ and have been used in caddisflies finding substitution rates as high as $5-6 \%$ per Ma for recently diverged taxa (less than $1 \mathrm{Ma}$ ), with rates 
rapidly decreasing with apparent age (Espeland \& Johanson $2010 a, b$ ). Divergences over 10\% in these studies are suggested to reflect ages well in excess of $5 \mathrm{Ma}$, for example divergences under $12 \%$ have been proposed as roughly $20 \mathrm{Ma}$ in age in the genus Agmina (Espeland \& Johanson $b$ ). Additionally, 16s shows an unusually high level of divergence between $C$. brevipennis and the remaining Chathamiidae, roughly the same found in COI despite the slower evolution rate of $16 \mathrm{~s}(\sim 3 \mathrm{x}$ slower in Papadopoulou et al. 2010). This may suggest further mutation of COI has slowed due to negative selection; further supporting a Pliocene age for $C$. brevipennis (a minimum age of $3.12 \mathrm{Ma}$ is suggested when both genes are combined).

Thus an ultimate minimum age of $2.46 \mathrm{Ma}$ is probably conservative and potentially much higher. If the divergence and the speciation of $C$. brevipennis is directly related to the allopatric event of dispersal to the Chatham islands, then the divergence must directly relate to continuous land in the region since the assumed time (additionally the lineage need not reflect the whole age of the island group). Alternatively $C$. brevipennis can be hypothesised as having originated from a now-extinct lineage from New Zealand and thus not directly related to the remaining Chathamiidae. This argument will always remain a possibility; as the in spite of their presumed antiquity (thus reaching family status) the Chathamiidae have a remarkably low diversity and are likely to have passed through a recent evolutionary bottleneck. An island group such as the Chathams may have provided a refuge for an older lineage of Chathamiids, only now recently extinct in New Zealand.

Two species flightless stag beetle from the Chatham Islands (Geodorcus spp.) were aged at $\sim 6 \mathrm{Ma}$ (Trewick 2000), although it was decided in the particular study the closest mainland relative was not included. Only three Geodorcus species (just one from the mainland) were analysed out of a described 17 (Holloway 1996, 2007) making this inference likley. All other divergences (see introduction section for full review) for Chatham Island invertebrates, including spiders, damselflies, cicadas, stick insects, cockroaches, isopods and amphipods show much more recent $\sim 1-2$ Ma arrivals within New Zealand. Similarly the endemic Chatham mudfish and the majority of the flora show a recent origin. No bird taxa are found to be any more recent than the mid-early Pleistocene; the entirety of the endemic Chatham avifauna is restricted to species or subspecies level. However three extinct 
monotypic bird genera; Pachyanas, Cabalus and Diaphorapteryx (Chatham Island duck, and Chatham and Hawkin's rails) were endemic to the islands and may have older origins (Holdaway et al. 2001).

High distances have however been found for at least four plant taxa (6.18-10.97 Ma, Heenan et al. 2008) and for the Chatham skink (5.86-7.29 Ma, Oligosoma nigiriplantare nigiriplantare, Liggins et al. 2008), although the closest mainland relatives to the Chatham skink may have not been sampled. For a hypothetical explanation regarding the old age of some plant taxa, Heenan et al. discussed the confirmed Miocene-Pliocene emergence of the Mangere volcano (Campbell \& Hutching 2007) and also cited the evidence of fossiliferous and palynological records of Opoitian (5.28-3.6 Ma) and Waipipian-Mangapanian (3.6-2.4 Ma) age, apparently carrying though to present (Mildenhall 1994). Also discussed was one Pliocene bone indistinguishable from the modern Chatham Pigeon (Hemiphaga chathamensis, Eagle et al. 2005), although this is now believed a recent Holocene intrusion (Worthy et al. 2009).

If the Mangere-volcano hypothesis is considered, there has been continuous land in the wider Chatham region for up to $6 \mathrm{Ma}$, as much as $4 \mathrm{Ma}$ longer than has been suggested by recent geological studies. It is possible that some of the Rangitihi Volcanics (the most recent of all the Chatham volcanoes) were emergent earlier, or that there was emergent land elsewhere in the Chatham Rise allowing for a tenacious evolutionary connection between the 'Mangere' and 'Chatham' biotas (Campbell et al. 1988, Heenan et al. 2010). Intertidal Chathamiids may have fared better than most terrestrial invertebrates and the skink $O$. nigiriplantare can survive on small rock stacks (McCann 1955), so both animals may have persisted through a geographical bottleneck. This explanation is purely conjectural and may be based off overestimated ages, however does explain why some of the Chatham biota appear to have Pliocene or even Miocene origins whilst the vast majority is evidently much younger. With this indicated more molecular studies should be undertaken of select taxa linking the Chatham Islands to New Zealand, and some taxa such as Geodorcus should be re-investigated. In addition the geological possibility of a Plio-Pleistocene link 2-4 Ma between Mangere volcano and the modern Chathams should perhaps be more seriously considered. 


\subsection{Figures}

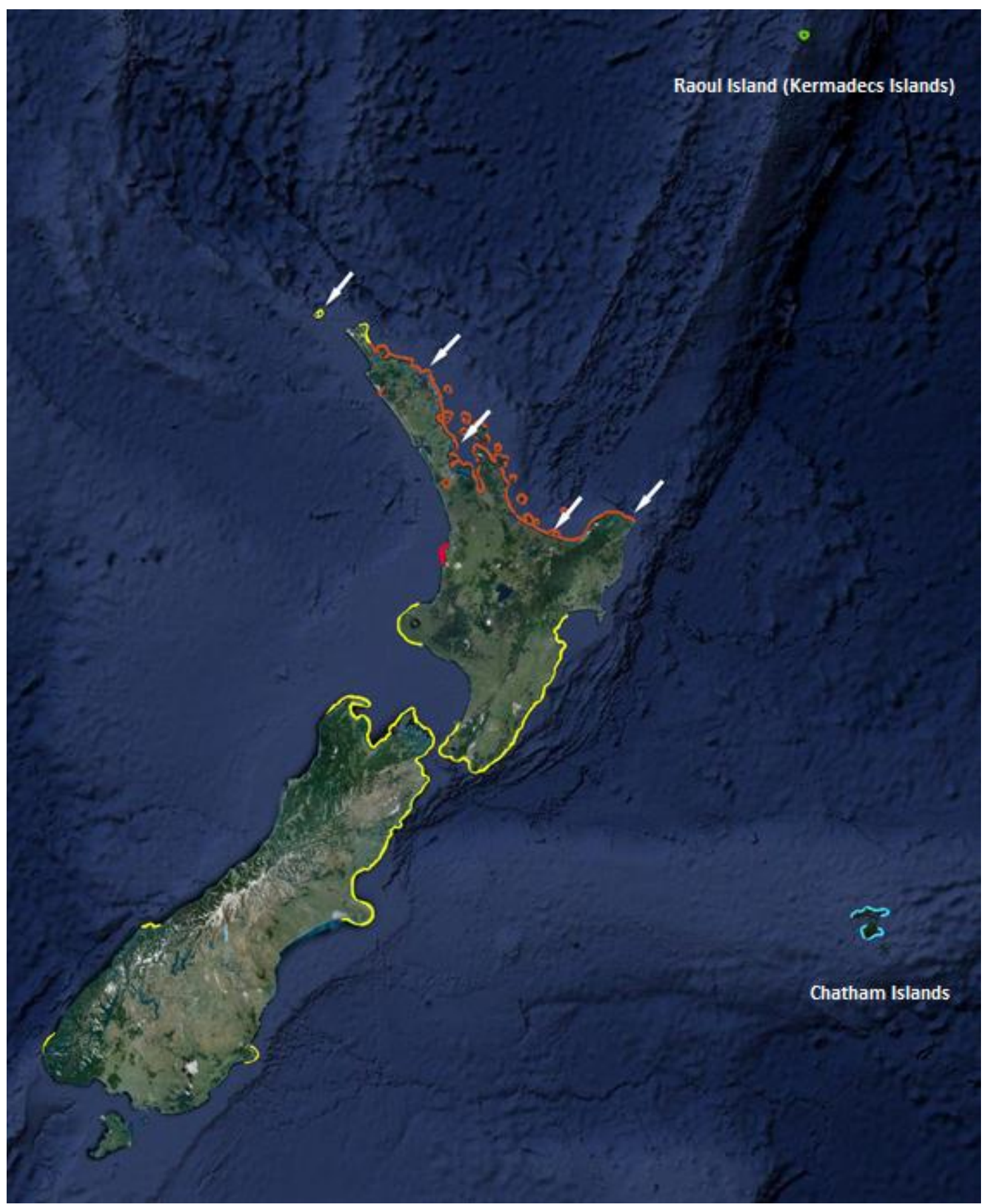

FIG 3.1) Estimated distribution of the Chathamiidae in New Zealand as inferred from collection records at the New Zealand trichoptera database (http://http://nzcaddis.massey.ac.nz/). As follows Yellow = Philanisus plebeius, Red = Chathamia integripennis, Orange = Philanisus plebeius $/$ Chathamia integripennis, Blue = Chathamia brevipennis, Green $=$ Philanisus fasciatus. White arrows designate the localities where Philanisus mataua has been collected. Not shown is the Australian distribution of Philanisus plebeius (Roughly 40km of coastline from Sydney Southwards), and also one dubious record from Stewart Island. Distribution disjunctions, especially in the South Island and the eastern North Island may reflect sampling bias. 


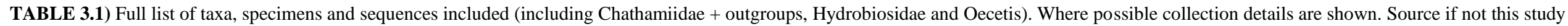

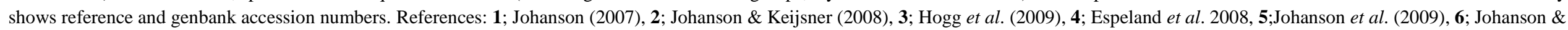
Espeland (2010), 7; Shan et al. (unpublished).

*Distribution of whole species, specific sample collection site unknown. $\quad * *$ Unidentified prior to sequencing.

\begin{tabular}{|c|c|c|c|c|c|c|c|c|c|}
\hline Species & Gene & Specimen No. & Ontogeny & No. & Source & Collector & Locality & Coordinates & Date \\
\hline Philanisus plebeius "A" & $\mathrm{COI} \& 16 \mathrm{~s}$ & L201 & Adult & 1 & This study & Ian Henderson & Marbourough Sounds & $41^{\circ} 14^{\prime} 25 \mathrm{~S}, 174^{\circ} 16^{\prime} 14 \mathrm{E}$ & $30 / 12 / 2008$ \\
\hline Philanisus plebeius "B" & COI \& 16s & A1002 & Adult & 1 & This study & Alex Boast & Tauranga & $37^{\circ} 42^{\prime} 29 \mathrm{~S}, 174^{\circ} 53^{\prime} 15 \mathrm{E}$ & $16 / 02 / 2009$ \\
\hline Philanisus plebeius "C" & COI \& $16 \mathrm{~s}$ & B303 & Adult & 1 & This study & Alex Boast & Mangakuri Beach & $39^{\circ} 57^{\prime} 59 \mathrm{~S}, 176^{\circ} 55^{\prime} 14 \mathrm{E}$ & $27 / 02 / 2009$ \\
\hline Philanisus mataua & COI & $\mathrm{PM} 2$ & Adult & 1 & This study & John Ward & Whangapaparoa & $36^{\circ} 35^{\prime} 35 \mathrm{~S}, 174^{\circ} 49^{\prime} 40 \mathrm{E}$ & 24/01/1993 \\
\hline Philanisus fasciatus & COI \& $16 \mathrm{~s}$ & PF101 & Adult & 1 & This study & Karen Baird & Raoul Island & $29^{\circ} 14^{\prime} 56 \mathrm{~S}, 177^{\circ} 55^{\prime} 14 \mathrm{E}$ & $20 / 10 / 2009$ \\
\hline Philanisus fasciatus & COI & PF102-3, 301-3 & Adult & 2 & This study & Karen Baird & Raoul Island & $29^{\circ} 14^{\prime} 56 \mathrm{~S}, 177^{\circ} 55^{\prime} 14 \mathrm{E}$ & $20 / 10 / 2009$ \\
\hline Chathamia integripennis & COI & CI1 & Adult & 1 & This study & Alex Boast & Waiwera & $36^{\circ} 32^{\prime} 56 \mathrm{~S}, 174^{\circ} 42^{\prime} 32 \mathrm{E}$ & $8 / 03 / 2009$ \\
\hline Chathamia integripennis & $\mathrm{COI}$ & CI201-2,301-2 & Adults & 4 & This study & Alex Boast & Mt. Maunganui & $37^{\circ} 37^{\prime} 30 \mathrm{~S}, 174^{\circ} 10^{\prime} 29 \mathrm{E}$ & $17 / 02 / 2009$ \\
\hline Chathamia integripennis & $\mathrm{COI}$ & 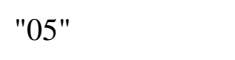 & - & 1 & 3 GU263323 & - & New Zealand* & - & - \\
\hline Chathamiia integripennis & COI & DP2 & - & 1 & 5 FJ263238 & - & New Zealand* & - & - \\
\hline Chathamia integripennis $* *$ & $\mathrm{COI}$ & K901 & Larva & 1 & This study & Alice Wells & Sydney & $33^{\circ} 49^{\prime} 25 \mathrm{~S}, 151^{\circ} 16^{\prime} 37 \mathrm{E}$ & $22 / 08 / 2008$ \\
\hline Chathamia brevipennis & COI \& $16 \mathrm{~s}$ & $\mathrm{CB} 1$ & Larva & 5 & This study & Alex Boast & Kaingaroa, Chat. Is. & $43^{\circ} 43^{\prime} 49 \mathrm{~S}, 176^{\circ} 16^{\prime} 07 \mathrm{E}$ & $14 / 02 / 2010$ \\
\hline Chathamia brevipennis & COI & CB2-5 & Larvae/Pupae & 4 & This study & Alex Boast & Kaingaroa, Chat. Is. & $43^{\circ} 43^{\prime} 49 \mathrm{~S}, 176^{\circ} 16^{\prime} 07 \mathrm{E}$ & $14 / 02 / 2010$ \\
\hline Olinga feredayi & COI \& $16 \mathrm{~s}$ & BM5 & - & 1 & 2 EF395045-4980 & - & New Zealand* & - & - \\
\hline Zelolessica cheira & COI \& 16s & $\mathrm{BP} 4$ & - & 1 & 2EF395047-4982 & - & New Zealand* & - & - \\
\hline Hydrobiosis lindsayi & COI & HB101-201 & Larva/Pupa & 2 & This study & Alex Boast & Awatotara Ck., Chat. Is. & $44^{\circ} 03^{\prime} 34 \mathrm{~S}, 176^{\circ} 37^{\prime} 12 \mathrm{E}$ & $15 / 02 / 2010$ \\
\hline Hydrobiosis lindsayi & COI & HB301 & Adult & 1 & This study & Alex Boast & Makara R. Chat. Is. & $43^{\circ} 59^{\prime} 19 \mathrm{~S}, 176^{\circ} 27^{\prime} 13 \mathrm{E}$ & $16 / 02 / 2010$ \\
\hline Hydrobiosis budgei & COI & "59" & - & 1 & 3 GU263339 & - & New Zealand* & - & - \\
\hline Hydrobiosis chardraea & $\mathrm{COI}$ & "47" & - & 1 & 3 GU263340 & - & New Zealand* & - & - \\
\hline Hydrobiosis copis & COI & "23" & - & 1 & 3 GU263344 & - & New Zealand* & - & - \\
\hline Hydrobiosis falcis & $\mathrm{COI}$ & "44" & - & 1 & 3 GU263345 & - & New Zealand* & - & - \\
\hline Hydrobiosis gollanis & COI & "09" & - & 1 & 3 GU263346 & - & New Zealand* & - & - \\
\hline Hydrobiosis harpidiosa & $\mathrm{COI}$ & "42" & - & 1 & 3 GU263347 & - & New Zealand* & - & - \\
\hline Hydrobiosis johnsi & $\mathrm{COI}$ & "39" & - & 1 & 3 GU263348 & - & New Zealand* & - & - \\
\hline
\end{tabular}


TABLE 3.1) Continued.

\begin{tabular}{|c|c|c|c|c|c|c|c|c|c|}
\hline Species & Gene & Specimen No. & Ontogeny & No. & Source & Collector & Locality & Coordinates & Date \\
\hline Hydrobiosis parumbripennis & COI & "22" & - & 1 & 3 GU263349 & - & New Zealand* & - & - \\
\hline Hydrobiosis soror & COI & "14" & - & 1 & 3 GU263352 & - & New Zealand* & - & - \\
\hline Hydrobiosis spatulata & COI & "08" & - & 1 & 3 GU263353 & - & New Zealand* & - & - \\
\hline Hydrobiosis styracine & COI & "21" & - & 1 & 3 GU263354 & - & New Zealand* & - & - \\
\hline Hydrobiosis umbripennis & COI & "60" & - & 1 & 3 GU263355 & - & New Zealand* & - & - \\
\hline Edpercivalia cassicola & COI & "43" & - & 1 & 3 GU263334 & - & New Zealand* & - & - \\
\hline Edpercivalia thomasoni & COI & "19" & - & 1 & 3 GU263335 & - & New Zealand* & - & - \\
\hline Atrachorema mangu & COI & "30" & - & 1 & 3 GU263321 & - & New Zealand* & - & - \\
\hline Costachorema callistum & COI & "45" & - & 1 & 3 GU263326 & - & New Zealand* & - & - \\
\hline Costachorema hecton & COI & "26" & - & 1 & 3 GU263327 & - & New Zealand* & - & - \\
\hline Costachorema xanthopterum & COI & "28" & - & 1 & 3 GU263330 & - & New Zealand* & - & - \\
\hline Neurochorema armstrongi & COI & "52" & - & 1 & 3 GU263358 & - & New Zealand* & - & - \\
\hline Neurochorema confusum & COI & "57" & - & 1 & 3 GU263361 & - & New Zealand* & - & - \\
\hline Psilochorema leptoharpax & COI & AO1 & - & 1 & 4 AM902790 & - & New Zealand* & - & - \\
\hline Psilochorema mimicum & COI & "18" & - & 1 & 3 GU263391 & - & New Zealand* & - & - \\
\hline Xanthochorema bifurcatum & COI & W2 & - & 1 & $1 \mathrm{DQ} 485522$ & - & New Caledonia* & - & - \\
\hline Moruya charadra & COI & DC6 & - & 1 & 6 FN179076 & - & Australia* & - & - \\
\hline Tiphobiosis cowiei & COI & "66" & - & 1 & 3 GU263407 & - & New Zealand* & - & - \\
\hline Tiphobiosis kleinpastei & COI & "72" & - & 1 & 3 GU263409 & - & New Zealand* & - & - \\
\hline Tiphobiosis veniflex & COI & "50" & - & 1 & 3 GU263410 & - & New Zealand* & - & - \\
\hline Synchorema zygoneura & COI & BY5 & - & 1 & 4 AM902799 & - & New Zealand* & - & - \\
\hline Apsilochorema hwangi & COI & $?$ & - & 1 & 7 AY490798 & - & China* & - & - \\
\hline Oecetis chathamensis & COI & OC201 & Adult & 1 & This study & Alex Boast & Henga L., Chat. Is. & $43^{\circ} 51^{\prime} 60 \mathrm{~S}, 176^{\circ} 33.12 \mathrm{E}$ & $12 / 02 / 2010$ \\
\hline Oecetis chathamensis & COI & OC601 & Adult & 1 & This study & Alex Boast & Te Whanga L., Chat. Is & $43^{\circ} 49^{\prime} 59 \mathrm{~S}, 176^{\circ} 30.19 \mathrm{E}$ & $14 / 02 / 2010$ \\
\hline Oecetis chathamensis & COI & OC701 & Adult & 1 & This study & Alex Boast & Makara R., Chat. Is. & $43^{\circ} 59^{\prime} 19 \mathrm{~S}, 176^{\circ} 27^{\prime} 13 \mathrm{E}$ & $16 / 02 / 2010$ \\
\hline Oecetis unicolor & COI & OC8-9 & Adult & 2 & This study & Alex Boast & St Arnaud & $41^{\circ} 48^{\prime} 12 \mathrm{~S}, 172^{\circ} 50.44 \mathrm{E}$ & $27 / 02 / 2010$ \\
\hline Oecetis unicolor & COI & OC11 & Adult & 1 & This study & Alex Boast & MangakuriBeach & $39^{\circ} 57^{\prime} 59 \mathrm{~S}, 176^{\circ} 55^{\prime} 14 \mathrm{E}$ & $5 / 12 / 2009$ \\
\hline
\end{tabular}


TABLE 3.2) List of primers used for amplification and sequencing.

\begin{tabular}{llll}
\hline & & & \\
Gene & Primer Name & Primer sequences $\left(\mathbf{5}^{\prime} \mathbf{-} \mathbf{3}^{\prime}\right)$ & Reference \\
\hline COI & HCO2198 & TAAACTTCAGGGTGACCAAAAAATCA & Folmer et al. 1994 \\
COI & LCO1490 & GGTCAACAAATCATAAAGATATTGG & Folmer et al. 1994 \\
COI & ChatP12 & GAAATACCAGCTAAATGTAAAG & This study \\
$16 \mathrm{~s}$ & $16 \mathrm{sARL}$ & CGCCTGTTTATCAAAAACAT & Palumbi (1996) \\
$16 \mathrm{~s}$ & $16 \mathrm{sBRH}$ & CCGGTCTGAACTCAGATCACGT & Palumbi (1996)
\end{tabular}

TABLE 3.3) Interspecific divergence means (d) for COI for all species sequenced for this study (except $P$. mataua), with standard error (S.E.). Calculated in MEGA v 4 with 10,000 replicates using the Kimura-2 parameter model.

\begin{tabular}{lrr}
\hline Species & d & \multicolumn{2}{c}{ S.E. } \\
\hline Philanisus plebeius & 0.013 & 0.004 \\
Philanisus fasciatus & 0.001 & 0.001 \\
Chathamia integripennis & 0.006 & 0.002 \\
Chathamia brevipennis & 0 & 0 \\
Hydrobiosis lindsayi & 0 & 0 \\
Oecetis chathamensis & 0.005 & 0.002 \\
Oecetis unicolor & 0.015 & 0.004
\end{tabular}

TABLE 3.4 ) Intraspecific pairwise divergence means for COI (bottom-left) between species of the Chathamiidae and outgroups with standard error (top-right). Calculated in MEGA v 4 with 10,000 replicates using the Kimura-2 parameter model.

$\begin{array}{lcccccr}\text { Species } & \text { 1) } & \text { 2) } & \text { 3) } & \text { 4) } & \text { 5) } & \text { 6) } \\ \text { 1) Philanisus plebeius } & & 0.006 & 0.006 & 0.013 & 0.018 & 0.017 \\ \text { 2) Philanisus fasciatus } & 0.027 & & 0.005 & 0.014 & 0.017 & 0.018 \\ \text { 3) Chathamia integripennis } & 0.026 & 0.016 & & 0.013 & 0.017 & 0.018 \\ \text { 4) Chathamia brevipennis } & 0.102 & 0.100 & 0.099 & & 0.019 & 0.018 \\ \text { 5) Olinga feredayi } & 0.179 & 0.170 & 0.167 & 0.198 & & 0.019 \\ \text { 6) Zelolessica cheira } & 0.167 & 0.171 & 0.175 & 0.176 & 0.196 & \end{array}$

TABLE 3.5) Intraspecific pairwise divergence means for 16S (bottom-left) between species of the Chathamiidae and outgroups with standard error (top-right). Calculated in MEGA v 4 with 10,000 replicates using the Kimura-2 parameter model.

$\begin{array}{lcccccr}\text { Species } & \text { 1) } & \text { 2) } & \text { 3) } & \text { 4) } & \text { 5) } & \text { 6) } \\ \text { 1) Philanisus plebeius } & & 0.005 & 0.003 & 0.015 & 0.021 & 0.020 \\ \text { 2) Philanisus fasciatus } & 0.010 & & 0.005 & 0.015 & 0.021 & 0.020 \\ \text { 3) Chathamia integripennis } & 0.005 & 0.010 & & 0.015 & 0.021 & 0.020 \\ \text { 4) Chathamia brevipennis } & 0.081 & 0.079 & 0.081 & & 0.020 & 0.021 \\ \text { 5) Olinga feredayi } & 0.163 & 0.160 & 0.163 & 0.154 & & 0.020 \\ \text { 6) Zelolessica cheira } & 0.148 & 0.142 & 0.148 & 0.166 & 0.154 & \end{array}$


TABLE 3.6) Intraspecific pairwise divergences between all Hydrobiosis and Epdercivalia sequences (down-right), with standard error (up-left). This study is concerned primarily with Hydrobiosis lindsayi only so other Hydrobiosidae were omitted from this analysis. Calculated in MEGA v 4 with 10,000 replicates using the Kimura-2 parameter model.

1) Hydrobiosis umbripennis

2) Hydrobiosis soror

3) Hydrobiosis spatulata

4) Hydrobiosis styracine

5) Hydrobiosis budgei

6) Hyrobiosis copis

7) Hydrobiosis falcis

8) Hydrobiosis harpidiosa

9) Hydrobiosis parumbripennis

10) Hydrobiosis johnsi

11) Hydrobiosis gollanis

12) Hydrobiosis charadraea

13) Hydrobiosis lindsayi

14) Edpercivalia cassicola

15) Edpercivalia thomasoni
1) 2) 3)

0.121 $0.014 \quad 0.016$

$0.140 \quad 0.136$

$0.077 \quad 0.152 \quad 0.156$

$\begin{array}{llll}0.081 & 0.152 & 0.170 & 0.099\end{array}$

$\begin{array}{llllll}0.081 & 0.137 & 0.150 & 0.082 & 0.072\end{array}$

$\begin{array}{lllllll}0.083 & 0.155 & 0.162 & 0.023 & 0.092 & 0.081\end{array}$

$\begin{array}{lllllll}0.156 & 0.133 & 0.152 & 0.176 & 0.163 & 0.165\end{array}$

$\begin{array}{lllllll}0.040 & 0.127 & 0.136 & 0.089 & 0.086 & 0.07\end{array}$

$\begin{array}{lllllll}0.066 & 0.141 & 0.146 & 0.081 & 0.111 & 0.08\end{array}$

$\begin{array}{lll}0.128 & 0.131 & 0.153\end{array}$

$0.161 \quad 0.134$

$0.072 \quad 0.141 \quad 0.154$

$\begin{array}{lll}0.168 & 0.152 & 0.168\end{array}$

$0.174 \quad 0.154 \quad 0.162$

$\begin{array}{lll}\text { 4) } & \text { 5) } & \text { 6) } \\ 0.011 & 0.011 & 0\end{array}$

$0.016 \quad 0.016$

$0.017 \quad 0.017$

0.01

011

$\begin{array}{ll}0.131 & 0.133\end{array}$

$\begin{array}{ll}0.131 & 0.133 \\ 0.179 & 0.173\end{array}$

$0.09 \quad 0.086$

0.130

0.173

$\begin{array}{ll}0.176 & 0.186\end{array}$

$0.197 \quad 0.189$

0.16

0.1 $\begin{array}{llll}1 & 0.006 & 0.018 & 0.012\end{array}$

$$
0.012
$$

$$
0.011
$$

0.181

0.091

0.079

0.125

0.169

0.087

8) 9)

1630.072

159

.1650 .1

165

0.154
10)

11)

$\begin{array}{ll}0.01 & 0.015\end{array}$

$\begin{array}{ll}0.016 & 0.015\end{array}$

$0.016 \quad 0.017$

$0.012 \quad 0.016$

$0.014 \quad 0.016$

$0.012 \quad 0.015$

$0.011 \quad 0.015$

$0.017 \quad 0.017$

$0.011 \quad 0.016$

0.016

0.1420 .148

$0.16 \quad 0.177$

0.094

0.126

$0.126 \quad 0.184$

$\begin{array}{llllll}G & A & A / C & T & A & T\end{array}$
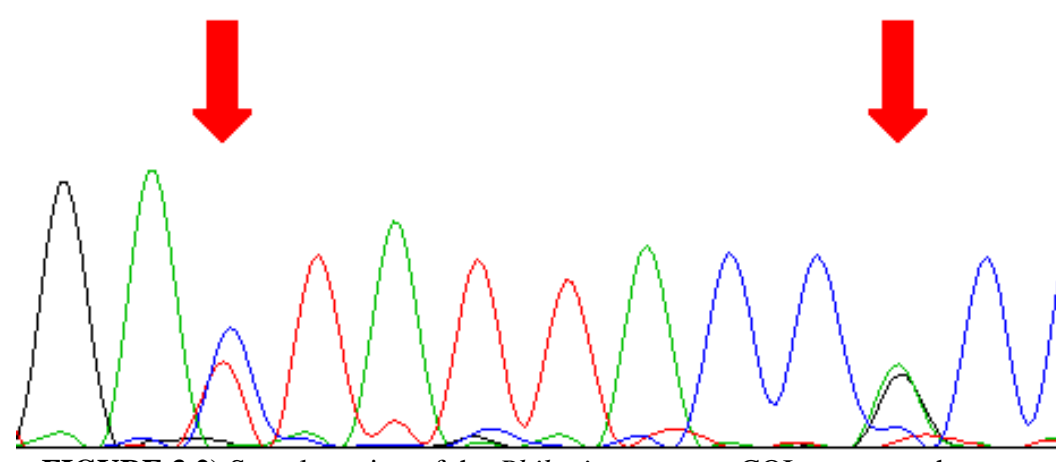

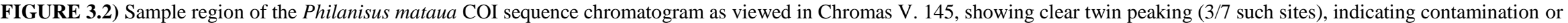
heteroplasmy. All such regions coincided with variable sites indicative either of Philanisus plebieus or Chathamia integripennis. 


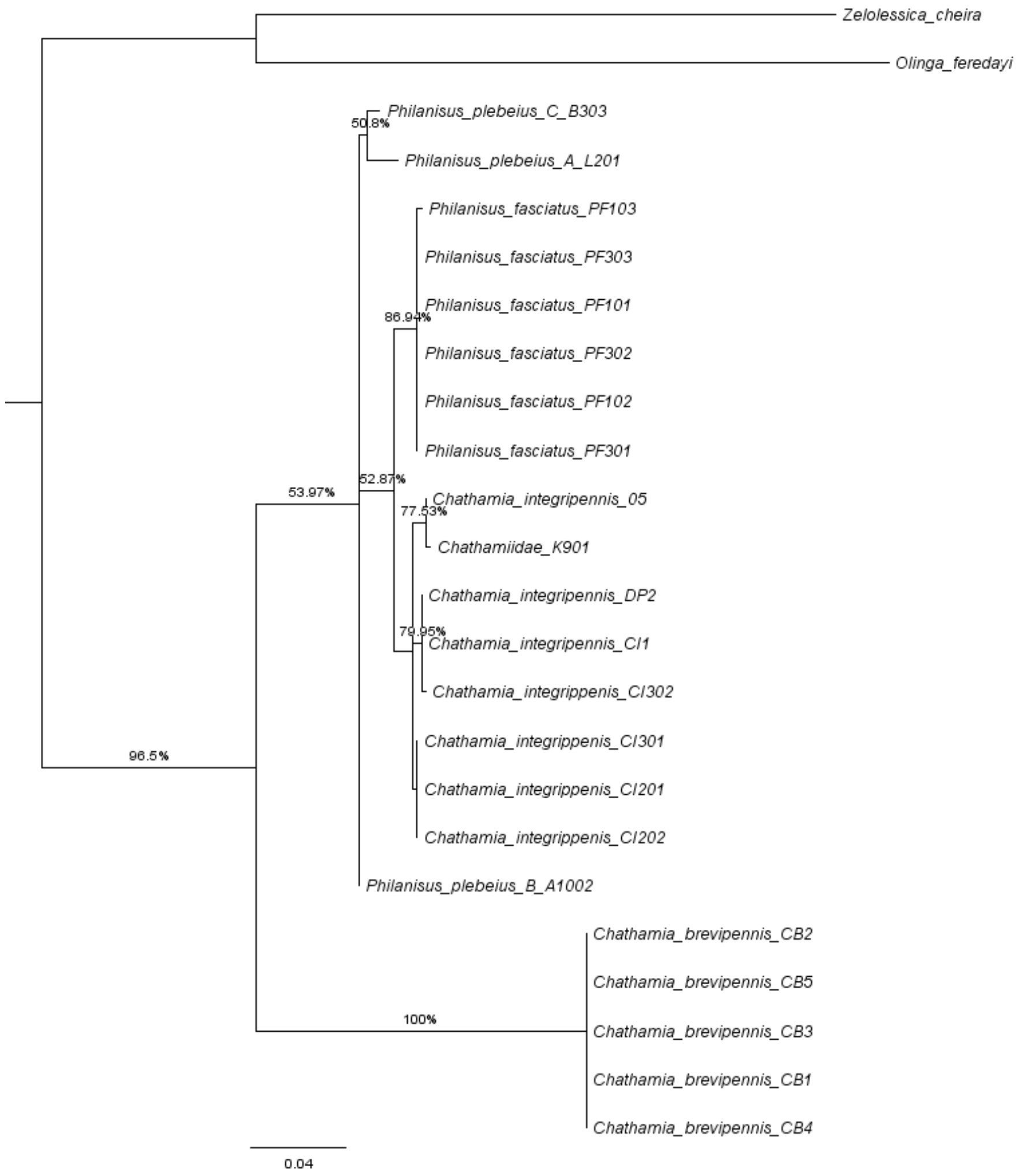

FIG 3.3) Bootstrap consensus Maximum likelihood (ML) tree of the Chathamiidae $(10,000,000$ replicates, Heuristic search logarithm) as inferred in PAUP* through COI data. Bootstrap values (\%) are shown. 


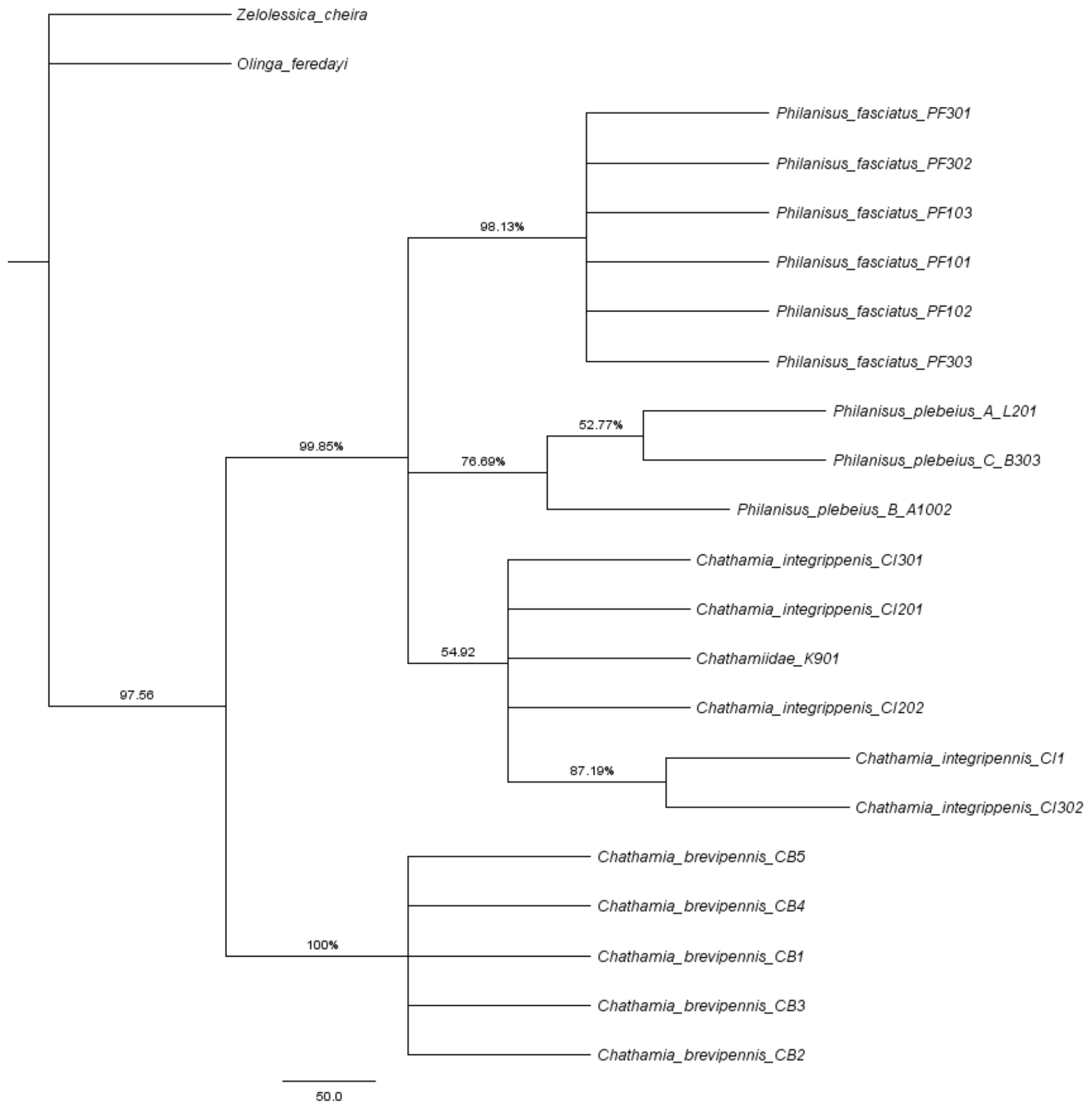

FIG 3.4) Bootstrap consensus Maximum Parsimony (MP) tree of the Chathamiidae $(10,000,000$ replicates, Heuristic search logarithm) as inferred in PAUP* through COI data. Bootstrap values (\%) are shown. 
Chapter Three: Phylogeny of the Chathamiidae

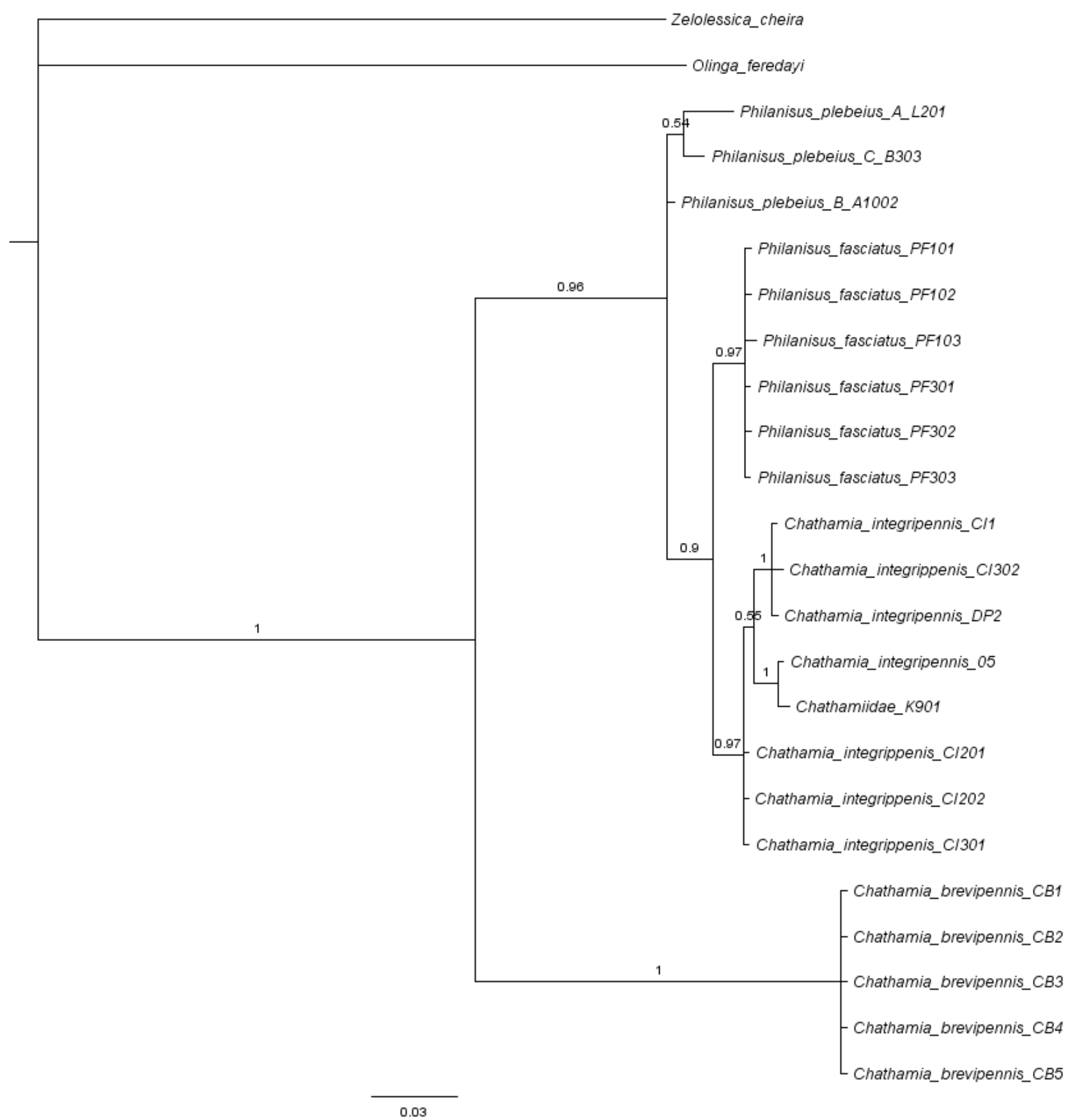

FIG 3.5) Bayesian analysis tree of the Chathamiidae as inferred by COI data and analysed through MrBayes. Posterior Bayesian probability indices are shown. 


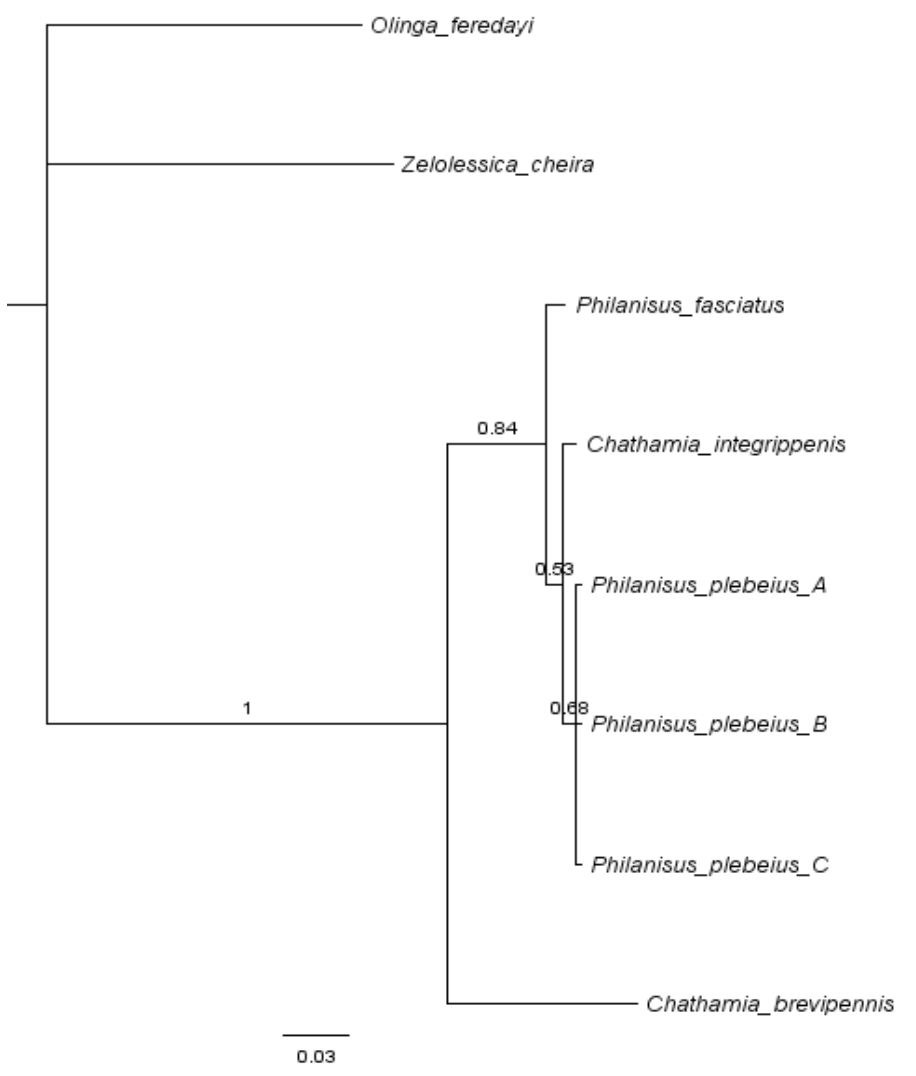

FIG 3.6) Bayesian analysis tree of the Chathamiidae as inferred by $16 \mathrm{~s}$ data and analysed through MrBayes. Posterior Bayesian probability indices are shown.

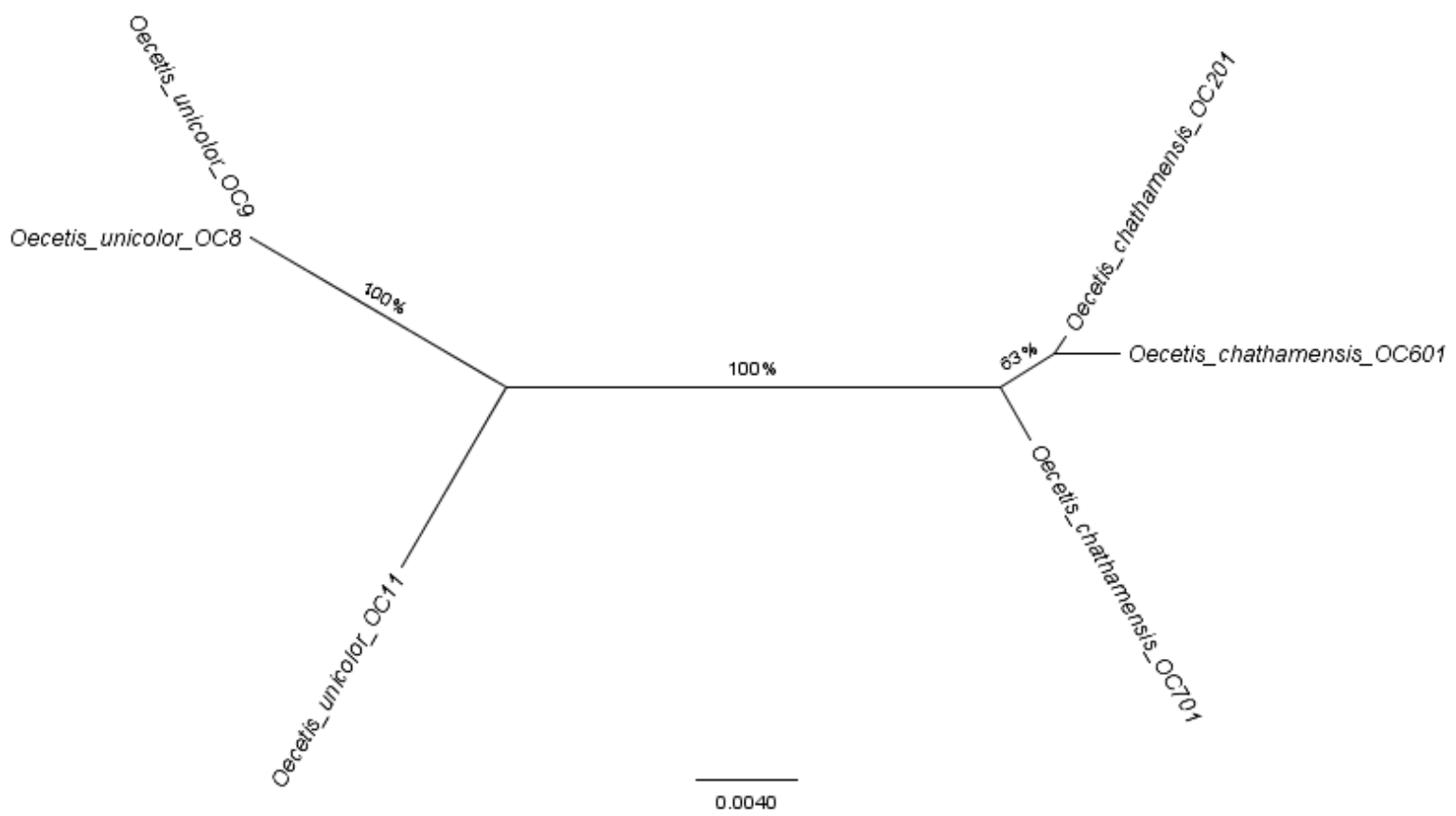

FIG 3.7) Unrooted neighbor joining tree of Oecetis chathamensis and O. unicolor as calculated in MEGA v 4. Separate species status is here supported.Bootstrap values shown from 10,000 replicates using maximum composite likelihood model(TamuraNei). 


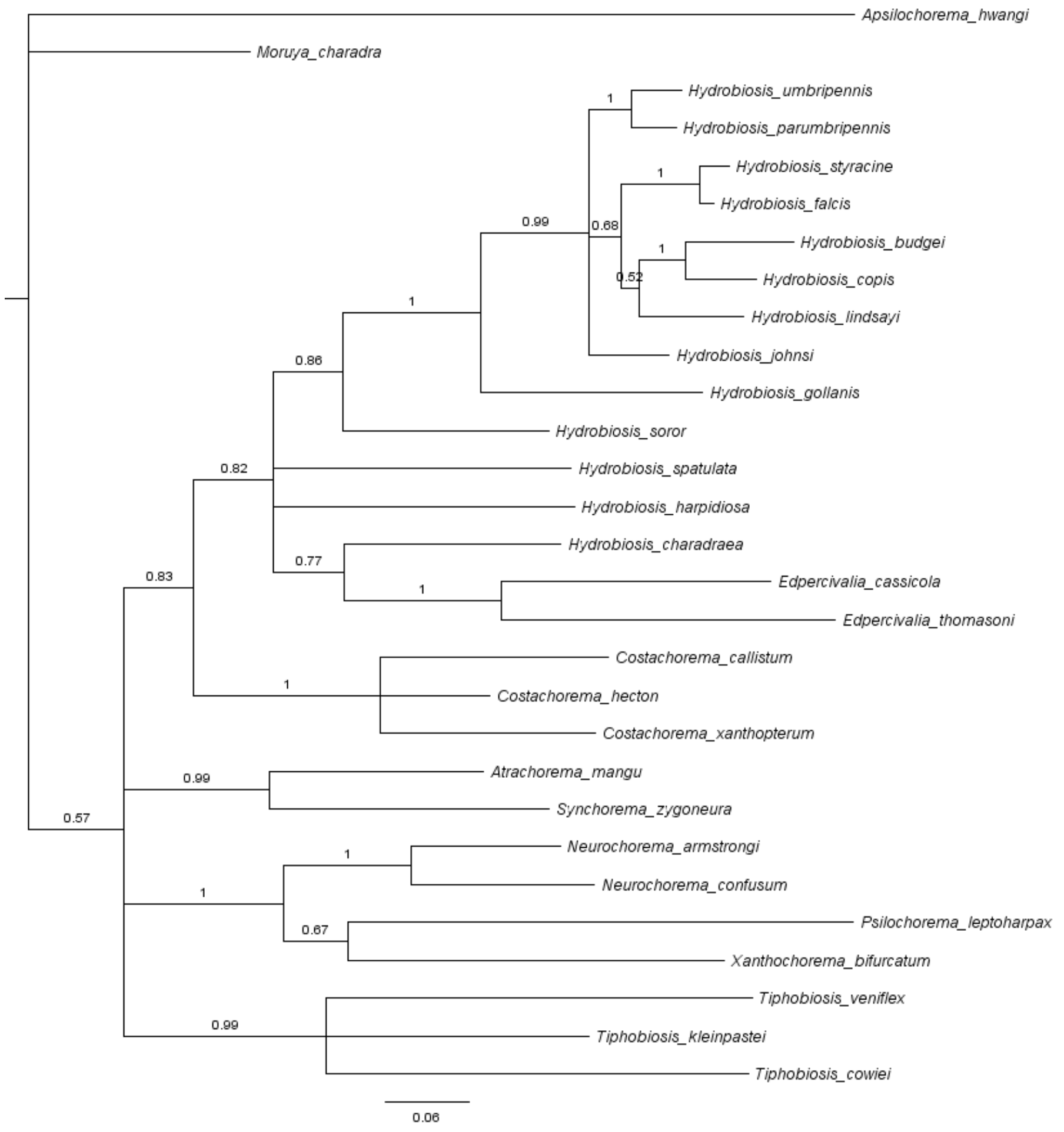

FIG 3.8) Bayesian analysis tree of the Hydrobiosidae primarily to infer the phylogenetic placement of the species Hydrobiosis lindsayi, as inferred by COI data and analysed through MrBayes. Posterior Bayesian probability indices are shown. 
Chapter Three: Phylogeny of the Chathamiidae
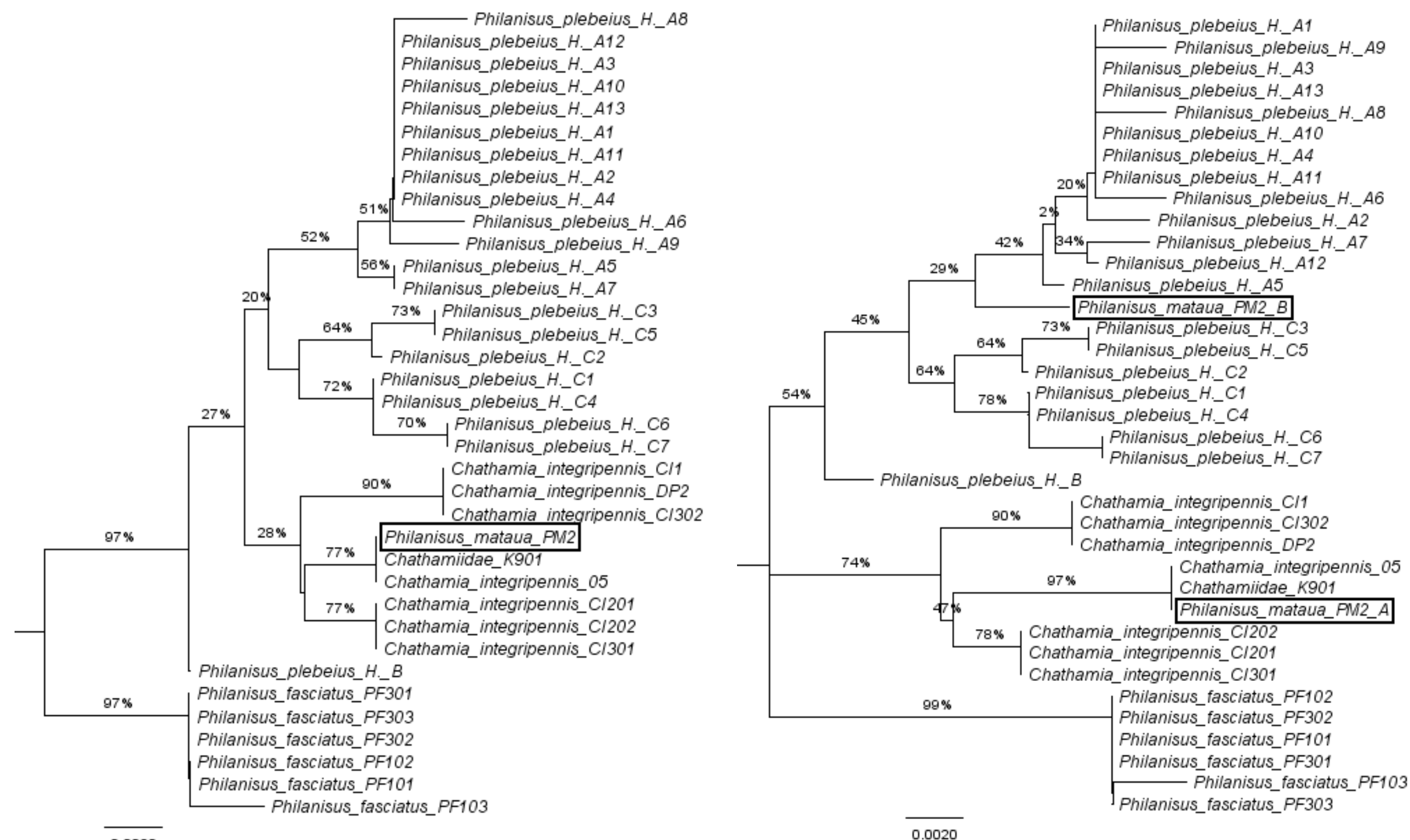

$\overline{0.0020}$

0.0020

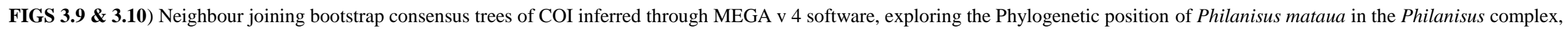

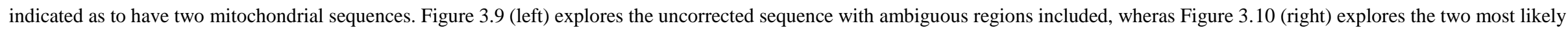
sequences ('A' \& 'B') and their independent phylogenetic placements. Bootstrap values based on 10,000 replicates, maxiumum composite likelihood model (Tamura - Nei). 
TABLE 3.7) Estimated age divergences in Ma as inferred through varying rough molecular clocks. Corrected (mean) pairwise divergence of each species to closest sister group (see methods for more detail) \pm Standard error; analysed for separately if possible for both COI and COI +16 s combined, calculated in MEGA v 4 with 10,000 replicates using the Kimura-2 parameter model. Clock 1 uses a $2.3 \%$ mitochondrial DNA divergence rate of $2.3 \%$ per Ma from Brower et al. (1994). Clock 2 uses the more recent divergences from Papadopoulou et al. (2010), with separate divergence estimates for COI (3.54\% per Ma) and COI+16s combined (2.69\% per Ma).

\begin{tabular}{|c|c|c|c|c|}
\hline Species & Gene & Corrected Divergence & $\begin{array}{l}\text { Age estimate (N) } \\
\text { Clock } 1(2.3 \%) \\
\end{array}$ & $\begin{array}{l}\text { Clock } 2 \\
(3.54 / 2.69 \%) \\
\end{array}$ \\
\hline \multirow[t]{2}{*}{ Chathamia brevipennis } & $\mathrm{COI}$ & $0.100 \pm 0.013$ & $4.35 \pm 0.56$ & $2.83 \pm 0.37$ \\
\hline & $\mathrm{COI}+16 \mathrm{~s}$ & $0.093 \pm 0.009$ & $4.04 \pm 0.39$ & $3.46 \pm 0.34$ \\
\hline \multirow[t]{2}{*}{ Philanisus plebeius } & $\mathrm{COI}$ & $0.027 \pm 0.005$ & $1.17 \pm 0.22$ & $0.76 \pm 0.14$ \\
\hline & $\mathrm{COI}+16 \mathrm{~s}$ & $0.019 \pm 0.004$ & $0.83 \pm 0.17$ & $0.71 \pm 0.15$ \\
\hline \multirow[t]{2}{*}{ Philanisus fasciatus } & COI & $0.016 \pm 0.005$ & $0.70 \pm 0.22$ & $0.45 \pm 0.14$ \\
\hline & $\mathrm{COI}+16 \mathrm{~s}$ & $0.012 \pm 0.003$ & $0.52 \pm 0.13$ & $0.45 \pm 0.11$ \\
\hline \multirow[t]{2}{*}{ Chathamia integripennis } & $\mathrm{COI}$ & $0.016 \pm 0.005$ & $0.70 \pm 0.22$ & $0.45 \pm 0.14$ \\
\hline & $\mathrm{COI}+16 \mathrm{~s}$ & $0.012 \pm 0.003$ & $0.52 \pm 0.13$ & $0.45 \pm 0.11$ \\
\hline Hydrobiosis lindsayi & $\mathrm{COI}$ & $0.083 \pm 0.009$ & $3.61 \pm 0.39$ & $2.35 \pm 0.25$ \\
\hline Oecetis chathamensis & $\mathrm{COI}$ & $0.034 \pm 0.006$ & $1.48 \pm 0.30$ & $0.96 \pm 0.17$ \\
\hline
\end{tabular}




\subsection{References:}

Arbogast BS, Edwards SV, Wakely J, Beerli P (2002). Estimating Divergence Times from Molecular Data on Phylogenetic and Population Genetic Timescales. Annual Review of Ecology and Systematics 33: 707-740

Arensburger P, Simon C, Holsinger K (2004). Evolution and phylogeny of the New Zealand cicada genus Kikihia Dugdale (Homoptera: Auchenorrhyncha: Cicadidae) with special reference to the origin of the Kermadec and Norfolk Island's species. Journal of Biogeography 31: 17691783

Arunkumar KP, Metta M, Nagaraju J (2006). Molecular phylogeny of silkmoths reveals the origin of domesticated silkmoth, Bombyx mori from Chinese Bombyx mandarina and paternal inheritance of Antheraea proylei mitochondrial DNA. Molecular Phylogenetics and Evolution 40: $419-427$

Baker AM, Williams SA, Hughes JM (2003). Patterns of spatial genetic structuring in a hydropsychid caddisfly (Cheumatopsyche sp. AV1) from southeastern Australia. Molecular Ecology 12: 3313-3324

Ballance PF, Ablaev AG, Pushchin IG, Pletnev SP, Birylina MG, Itaya T, Follas HA, Gibson GW (1999). Morphology and history of the Kermadec trenc-arc-backarc-basin-remnant arc system at 30 to $32^{\circ} \mathrm{S}$ : geophysical profile, microfossil and K-Ar data. Marine Geology 159: $35-62$

Banks JC, Paterson AM (2007). A preliminary study of the genetic differences in New Zealand oystercatcher species. New Zealand Journal of Zoology 34: 141-144

Barkla JW, Dilks PJ, Greene TC, Griffiths R (2010). Homolanthus polyandrous (Euphorbiaceae) on Macauley Island, southern Kermadec Islands, with notes on that island's vascular flora. New Zealand Journal of Botany 46: 373-379

Ballard JWO, Whitlock MC (2004). The incomplete natural history of mitochondria. Molecular Ecology 13: 729-744

Blahnik RJ (1995). New species of Smicridea (subgenus Smicridea) from Costa Rica, with a revision of the fasciatella complex (Trichoptera: Hydropsychidae). Journal of the North American Benthological Society 14: 84-107

Boon WM, Kearvell JC, Daugherty CH, Chambers GK (2000). Molecular systematics of New Zealand Cyanoramphus parakeets: conservation of Orange-fronted and Forbes' Parakeets. Bird Conservation International 10: 211-239

Boon WM, Daugherty CH, Chambers GK (2001). The Norfolk Island Green Parrot and New Caledonian Red-crowned Parakeet are distinct species. Ети 101: 113-121

Botosaneanu L, Wichard W (1983). Upper-Cretaceous Amber Trichoptera. In Proceedings of the fourth International Symposium on Trichoptera Ed. JC Morse pp 43-49.Dr W. Junk Publishers, The Hague. 
Brothers RN, Martin KR (1970). The Geology of Macauley Island, Kermadec Group, Southwest Pacific. Bulletin Volcanologique 34: 330-346

Brothers RN, Searle EJ (1970). The Geology of Raoul Island, Kermadec Group, Southwest Pacific. Bulletin Volcanologique 34: 7-37

Brower AVZ (1994). Rapid morphological radiation and convergence and convergence among races of the butterfly Heliconius eratoinferred from patterns of mitochondrial DNA evolution. Proceedings of the National Academy of Sciences of the USA 91: 6491-6495

Brown W Jr, George M Jr, Wilson AC (1979). Rapid evolution of animal mitochondrial DNA. Proceedings of the National Academy of Science of the USA 76: 1967-71

Brown W, Prager EM, Wang A, Wilson AC (1982). Mitochondrial DNA sequences of primates: tempo and mode of evolution. Journal of Molecular Evolution 18: 225-239

Campbell HJ (1998). Fauna and flora of the Chatham Islands: less than 4 my old? 'Geology and Genes’ III Geological Society of New Zealand Miscellaneous Publication 97: 15-16

Campbell HJ, Andrews PB, Beu AG, Edwards AR, Hornibrook Nde B, Laird MG, Maxwell PA, Watters WA (1988). Cretaceous-Cenozoic lithostratigraphy of the Chatham Islands. Journal of the Royal Society of New Zealand 18: 285-308

Campbell HJ, Andrews PB, Beu AG, Maxwell PA, Edwards AR, Laird MG, Hornibrook D De B, Mildenhall DC, Watters WA, Buckeridge JS, Lee DE, Strong CP, Wilson GJ, Hayward BW (1994). Cretaceous-Cenozoic geology and biostratigraphy of the Chatham Islands. Institute of Geological \& Nuclear Sciences Monograph no 2, 269 pp

Cambell HJ, Begg JC, Beu AG (2006). On the turn of a scallop. 'Geology and Genes' III Geological Society of New Zealand Miscellaneous Publication 121: 9

Campbell HJ, Begg J, Beu A, Carter B, Curtis N, Davies G, Emberson R, Given D, Goldberg J, Holt K, Hoernlie K, Malahoff A, Mildenhall D, Landis C, Paterson A, Trewick S (2008). Geological considerations relating to the Chatham Islands, mainland New Zealand and the history of New Zealand terrestrial life. Geological Society of New Zealand Miscellaneous Publication 126: 5-6

Campbell HJ, Hutching G (2007). In Search of Ancient New Zealand. Penguin Books, London.

Chambers GK, Boon WM, Buckley TR, Hitchmough RA (2001). Using molecular methods to understand the Gondwanan affinities of the New Zealand biota: three case studies. Australian Journal of Botany 49: 377-387

Champion PD, Clayton JS (2004). Aquatic vegetation of Chatham Island (Rekohu). DOC Science Internal Series 164.

Chinn WG, Gemmell NJ (2004). Adaptive radiation within New Zealand endemic species of the cockroach genus Cellatoblata Johns (Blattidae): a response to Plio-Pleistocene mountain building and climate change. Molecular Ecology 13: 1507-1518

Clarkson AD (1990). A review of vegetation development following recent ( $<450$ years) volcanic disturbance in North Island, New Zealand. New Zealand Journal of Ecology 14: 59-71 
Collier K (1993). Review of the status, distribution, and conservation of freshwater invertebrates in New Zealand. New Zealand Journal of Marine and Freshwater Research 27: 339-356

Craw R (1988). Continuing the synthesis between panbiogeography, phylogenetic systematics and geology as illustrated by empirical studies on the biogeography of New Zealand and the Chatham Islands. Systematic Zoology 37: 291-310

de Moor FC, Ivanov (2008). Global diversity of caddisflies (Trichoptera: Insecta) in freshwater. Hydrobiologia 595: 393-407

Dugdale JS (1973). A note on Kermadec Islands Lepidoptera. New Zealand Entomologist 5: 197-199

Eagle MKB, Gill BJ, Grant-Mackie JA (2005). Pliocene bird bones from Pitt Island, Chatham Islands, New Zealand. Records of the Auckland Museum 42: 67-73

Emberson RM (1995). The Chathams Islands beetle fauna and the age of separation of the Chatham Islands from New Zealand. New Zealand Entomologist 18: 1-7

Emberson RM (1998). The beetle (Coleoptera) fauna of the Chatham Islands. New Zealand Entomologist 21: 25-64

Espeland M, Johanson KA, Hovmöller R (2008). Early Xanthochorema (Trichoptera, Insecta) radiations in New Caledonia originated on ultrabasic rocks. Molecular Phylogenetics and Evolution 48: 904-917

Espeland M, Johanson KA (2010) $a$. The effect of environmental diversification on species diversification in New Caledonian caddisflies (Insecta: Trichoptera: Hydropsychidae). Journal of Biogeography 37: 879-890

Espeland M, Johanson KA (2010) $b$. The diversity and radiation of the largest monophyletic animal group on New Caledonia (Trichoptera: Ecnomidae: Agmina). Journal of Evolutionary Biology 23: $2112-2122$

Farris JS (1970). Methods for computing Wagner trees. Systematic Zoology 18: 274-385

Felsenstein J (1981). Evolutionary trees from DNA sequences: a maximum likelihood approach. Journal of Molecular Evolution 17: 386:376

Folmer O, Black M, Hoeh W, Lutz R, Vrijenhoek R (1994). DNA primers for amplification of mitochondrial cytochrome $\mathrm{c}$ oxidase subunit I from diverse metazoan invertebrates. Molecular Marine Biology and Biotechnology 3: 294-299

Fontaine KM, Cooley JR, Simon C (2007). Evidence for Paternal Leakage in Hybrid Periodical Cicadas (Hemiptera: Magicicada spp.) PLoS ONE 9: 892

Gardner RC, de Lange PJ, Keeling DJ, Bowala T, Brown HA, Wright SD (2004). A late Quaternary phylogeography for Metrosideros (Myrtaceae) in New Zealand inferred from chloroplast DNA haplotypes. Biological Journal of the Linnaean Society 83: 399-412

Gaunt MW, Miles MA (2002). An Insect Molecular Clock Dates the Origin of the Insects and Accords with Paleontological and Biogeographic Landmarks. Molecular Biology and Evolution 19: 748-761 
Gibbs G (2005). Ghosts of Gondwana: a history of life in New Zealand. Craig Potton Publishing, Nelson.

Gratton P, Konopiński MK, Sbordoni V (2008). Pleistocene evolutionary history of the Clouded Apollo (Parnassius Mnemosyne). Molecular Ecology 17: 4228-4262

Gyllensten UD, Wharton A, Josefson, Wilson A (1991). Paternal inheritance of mitochondrial DNA in mice. Nature 352: 255-257

Hay RF, Mutch AR, Watters WA (1970). Geology of the Chatham Islands. New Zealand Geological Survey 83: 753-757

Heenan PB, Mitchell AD, de Lange PJ, Keeling J, Paterson AM (2010). Late-Cenozoic origin and diversification of Chatham Islands endemic plant species revealed by analyses of DNA sequence data. New Zealand Journal of Botany 48: 83-136

Hogg ID, Smith BJ, Banks JC, Dewaard JR, Hebert PDN (2009). Testing use of mitochondrial COI sequences for the identification and phylogenetic analysis of New Zealand caddisflies (Trichoptera). New Zealand Journal of Marine and Freshwater Research 43: 1137-1146

Holdaway RN, Worthy TH, Tennyson AJD (2001). A working list of breeding birds of the New Zealand region at first human contact. New Zealand Journal of Zoology

Holloway BA (1996). Two new genera of New Zealand stag beetles previously treated as Dorcus MacLeay and Lissotes Westwood (Coleoptera: Lucanidae). New Zealand Journal of Zoology 23: 61-66

Holloway BA (2007). Lucanidae (Insecta: Coleoptera). Fauna of New Zealand (61)

Hudson GV (1904). New Zealand Neuroptera.(West, Newman \& Co.; London).

Huelsenbeck JP, Ronquist F (2001). MRBAYES: Bayesian inference of phylogenetic trees. Bioinformatics 17: 754-755

Johanson KA (2007). Association and description of males, females and larvae of two New Caledonian Xanthochorema species (Trichoptera: Hydrobiosidae) based on mitochondrial 16S and COI sequences. Entomological Science 10: 179-199

Johanson KA, Keijsner M (2008). Phylogeny of the Helicophidae (Trichoptera), with emphasis on the New Caledonian species of Helicopha. Systematic Entomology 33: 451-483

Johanson KA, Kjer K, Malm T (2009). Testing the monophyly of the New Zealand and Australian endemic family Conoesucidae Ross based on combined molecular and morphological data (Insecta: Trichoptera: Sericostostomatoidea). Zoologica Scripta 38: 563-573

Johanson KA, Espeland M (2010). Phylogeny of the Ecnomidae (Insecta: Trichoptera). Cladistics 26: $36-48$

Johanson KA, Malm T. (2010). Testing the monophyly of Calocidae (Insecta: Trichoptera) based on multiple molecular data. Molecular Phylogenetics and Evolution 54: 535-541

Kaplin PA (1981). Relief, Age, and Types of Oceanic Islands. New Zealand Geographer 37: 3-12 
Kaneda H, Hayashi JI, Takahama S, Jaya C, Lindahl KF, Yonekawa H (1995). Elimination of paternal mitochondrial DNA in intraspecific crosses during early mouse embryogenesis. Proceedings of the National Academy of Sciences of the USA 92: 4542-4546

Kennedy M, Gray RD, Spencer HG (2000). The Phylogenetic Relationships of the Shags and Cormorants: Can Sequence Data Resolve a Disagreement between Behavior and Morphology? Molecular Phylogenetics and Evolution 17: 345-359

Kondo R, Satta Y, Matsuura ET, Ishiwa H, Takahata N,Chigusa SI (1990). Incomplete Maternal Transmission of Mitochondrial DNA in Drosophila. Genetics 126: 657-663

Kjer KM, Blahnik RJ, Holzenthal (2001). Phylogeny of Trichoptera (Caddisflies): Characterisation of Signal and Noise within Multiple Datasets. Systematic Biology 50: 781-816

Kjer KM, Blahnik RJ, Holzenthal (2002). Phylogeny of caddisflies (Insecta, Trichoptera). Zoologica Scripta 31: 83-91

Kumar K, Dudley J, Nei M, Kumar S (2007). MEGA4: Molecular Evolutionary Genetics Analysis software version 4.0. Molecular Biology and Evolution 24: 1596-1599.

Kumar K, Dudley J, Nei M, Kumar S (2008). MEGA: A biologist-centric software for evolutionary analysis of DNA and protein sequences. Briefings in Bioinformatics 9: 299-306

Kvist L, Martens J, Nazarenko AA, Orell M (2003). Paternal Leakage of Mitochondrial DNA in the Great Tit (Parus major). Molecular Biology and Evolution 20: 243-247

Lansman RA, Avise JC, Huettel MD (1983). Critical experimental test of the possibility of "paternal leakage" of mitochondrial DNA. Proceedings of the National Academy of Sciences of the USA 80: 1969-1971

Latter JH, Lloyd EF, Smith IEM, Nathan S (1992). Volcanic Hazards in the Kermadec Islands and at Submarine Volcanoes between Southern Tonga and New Zealand. Ministry of Civil Defence Volcanic Hazards Information Series 4: 42 pp.

Leader JP (1976). Marine caddisflies (Trichoptera: Philanisidae). Marine Insects (ed. By L. Cheng), pp. 191-302. North Holland, Amsterdam.

Leese F (2004). Molecular genetic, chemotaxonomic, and autecological investigations of European Sericostomatidae (Insecta: Trichoptera). 1-137. Diploma-thesis. Fakultät für Biologie der Ruhr-Universität Bochum.

Lehrian S, Pauls SU, Haase P (2010). Genetic structure of an autumn-emerging caddisfly with inherently low dispersal capacity and insights into its phylogeography. Journal of the North American Benthological Society 29: 1100-1118

Librado P, Rozas J (2009). DnaSP v5: A software for comprehensive analysis of DNA polymorphism data. Bioinformatics 25: 1451-1452

Liggins L, Chapple DG, Daugherty CH, Ritchie P (2008). Origin and post-colonization evolution of the Chatham Islands skink (Oligosoma nigriplantare nigriplantare). Molecular Ecology 17: 3290-3305 
Lloyd EF, Nathan S (1981). Geology and tephrochronology of Raoul Island, Kermadec Group, New Zealand.NZ Geological Survey Bulletin 95 pp 105

Lloyd EF, Nathan S, Smith IEM, Stewart RB (1996). Volcanic history of Macauley Island, Kermadec Ridge, New Zealand. New Zealand Journal of Geology and Geophysics 39: 295-208.

Magnacca KN, Brown MJF (2010) $a$. Mitochondrial heteroplasmy and DNA barcoding in Hawaiian Hylaeus (Nesoprosobis) bees (Hymenoptera: Colletidae). BMC Evolutionary Biology 10: 174

Magnacca KN, Brown MJF (2010) $b$. Tissue segregation of mitochondrial haplotypes in heteroplasmic Hawaiin bees: implications for DNA barcoding. Molecular Ecology Resources 10: $60-68$

Malicky H (1992). Köcherfliegen (Trichoptera) von den Kapverdischen inseln. Zeitschrift der Arbeitsgemeinschaft Österreichische Etomologen 34: 106-110

Marris JWM (2000). The beetle (Coleoptera) fauna of the Antipodes Islands, with comments on the impact of mice; and an annotated checklist of the insect and arachnid fauna. Journal of the Royal Society of the New Zealand 2: 169-195

Marshall DC, Slon K, Cooley JR, Hill KBR, Simon C (2008). Steady Plio-Pleistocene diversification and a 2-million-year sympatry threshold in a New Zealand cicada radiation. Molecular Phylogenetics and Evolution 48: 1054-1066

Matsuura ET, Niki Y, Chigusa SI (1991). Selective transmission of mitochondrial DNA in heteroplasmic lines for intra- and interspecific combinations in Drosophila melanogaster. Japanese Journal of Genetics 66: 197-207

McCann C (1955). The lizards of New Zealand. Gekkonidae and Scincidae. Dominion Museum Bulletin 17: 1-127

McGaughran A, Hogg ID, Stevens MI, Chadderton WL, Winterbourn MJ (2006). Genetic divergence of three freshwater isopod species from southern New Zealand. Journal of Biogeography 33: $23-30$

Mecom JO (1972). Feeding habits of Trichoptera in a mountain stream. Oikos 23: 401-407

Meusel MS, Moritz RFA (1993). Transfer of paternal mitochondrial DNA during fertilization of honeybee (Apismellifera L.) eggs. Current Genetics 24: 539-543

Michaeux B, Leschen RAB (2005). East meets west; biogeology of the Campbell Plateau. Biological Journal of the Linnean Society 86: 95-115

Mildenhall DC (1994). Palynological reconnaissance of early Cretaceous to Holocene sediments, Chatham Islands, New Zealand. Institute of Geological and Nuclear Sciences Monograph 7

Miller HC, Lambert DM (2006). A molecular phylogeny of New Zealand's Petroica (Aves: Petroicidae) species based on mitochondrial DNA sequences. Molecular Phylogenetics and Evolution 40: 844-855

Neboiss A (1977). A taxonomic and zoogeographic study of Tasmanian caddis-flies (Insecta: Trichoptera). Memoirs of the National Museum of Victoria 38: 1-208 
Neboiss A (1986). Atlas of Trichoptera of the SW Pacific-Australian Region. Dr W Junk Publishers, Dordrecht, pp286

Nolan L, Hogg ID, Sutherland DL, Stevens MI, Schnabel (2007). Allozyme and mitochondrial DNA variabiligy within the New Zealand damselfly genera Xanthocnemis, Austrolestes, and Ischnura (Odonata). New Zealand Journal of Zoology 34: 371-380

Paduan KDS, Ribolla PEM (2008). Mitochondrial DNA Polymorphism and Heteroplasmy in Populations of Aedes aegypti in Brazil.Journal of Medical Entomology 45: 59-67

Palumbi S, Martin A, Romano S, McMillan WO, Stice L, Grabowski G (1991). The Simple Fool's Guide to PCR. Department of Zoology, University of Hawaii, Honolulu.

Papadopoulou A, Anastasiou I, Volger AP (2010). Revisiting the Insect Mitochondrial Molecular Clock: The Mid-Aegean Trench Calibration. Molecular Biology and Evolution 27: 1659-1672

Paterson A, Trewick S, Armstrong K, Goldberg J, Mitchell A (2006). Recent and emergent: Molecular analysis of the biota supports a young Chatham Islands. 'Geology and Genes' III Geological Society of New Zealand Miscellaneous Publication 121: 27-29

Pauls S (2004). Phylogeny and phylogeography of the montane caddisfly Drusus discolour (Rambur, 1842) (Trichoptera: Limnephilidae, Drusinae). PhD-Thesis, University of DuisbergEssen.http://miless.uni-duisburg-essen.de/servlets/DocumentSurvlet?id=11665

Pauls SU, Lumbsch T, Haase P (2006). Phylogeography of the montane caddisfly Drusus discolor: evidence for multiple refugia and periglacial survival. Molecular Ecology 15: 1253-2169

Pauls SU, Theissinger K, Ujvarosi L, Balint M, Haase P (2009). Patterns of population structure in two closely related, partially sympatric caddisflies in Eastern Europe: historic introgression, limited dispersal, and cryptic diversity. Journal of the North American Benthological Society 28: $517-536$

Pauls SU, Blahnik RJ, Zhou X, Wardwell CT, Holzenthal RW (2010). DNA barcode data confirm new species and reveal cryptic diversity in Chilean Smicridea (Smicridea) (Trichoptera:Hydropsychidae). Journal of the North American Benthological Society 29: 1058-1074

Piganeau G, Gardner M, Eyre-Walker AE (2004). A Broad Survey of Recombination in Animal Mitochondria. Molecular Phylogenetics and Evolution 21: 2319-2325

Posada D, Crandall KA (1998). MODELTEST: testing the model of DNA substitution. Bioinformatics 14: 817-818

Posada D, Crandall KA (2002). The effect of Recombination on the Accuracy of Phylogeny Estimation. Journal of Molecular Evolution 54: 396-402

Previšić A, Walton C, Kučinić M, Mitrikeski PT, Kerovec M (2009). Pleistocene divergence of Dinaric Drusus endemics (Trichoptera, Limnephilidae) in multiple microrefugia within the Balkan Peninsula. Molecular Ecology 18: 634-647

Riek E.F. (1970). Trichoptera. In CSIRO "Insects of Australia". (Melbourne University Press: Melbourne). 
Riek EF (1976). The marine caddisfly family Chathamiidae (Trichoptera). Journal of the Australian Entomological Society 15: 405-419

Ronquist F, Huelsenbeck JP (2003). MrBayes 3: Bayesian phylogenetic inference under mixed models. Bioinformatics 19: 1572-1574

Sackton TB, Haney RA, Rand DM (2003). Cytonuclear coadapation in Drosophila: disruption of cytochrome c oxidase activity in backcross genotypes. Evolution 57: 2315-2325

Satta Y, Toyohara N, Ohtaka C, Tatsuno Y, Watanabe, Matsuura ET, Chigusa SI, Takahata N (1988). Dubious maternal inheritence of mitochondrial DNA in D. siumulans and evolution of $D$. mauritiana. Genetical Research 52: 1-6

Schmid F (1989). Les Hydrobiosides (Trichoptera, Annulpalpia). Bulletin de L'institut Royal des Sciences Naturelles de Belgique, Entomologie 59: (Suppl.) : 1-154

Shepherd LD, de Lange PJ, Perrie LR (2009). Multiple colonizations of a remote oceanic archipelago by one species: how common is long-distance dispersal? Journal of Biogeography 36: 19721977

Sherengul W, Kondo R, Matsuura ET (2006). Analysis of paternal transmission of mitochondrial DNA in Drosophila. Genes \& Genetic Systems 81: 399-404

Smith BJ (1998). The larva of Hydrobiosis gollanis Mosely (Trichoptera: Hydrobiosidae). New Zealand Journal of Zoology 25: 421-428

Smith IEM, Brothers RN, Muiruri FG, Browne PRL (1988). The geochemistry of rock and water samples from Curtis Island Volcano, Kermadec Group, Southwest Pacific. Journal of Volcanology and Geothermal Research 34: 233-240

Smith IEM, Stewart RB, Price RC (2003) a. The petrology of a large intra-oceanic silicic eruption: the Sandy Bay Tephra, Kermadec Arc, Southwest Pacific. Journal of Volcanology and Geothermal Research 124: 173-194

Smith IEM, Worthington TJ, Stewart RB, Price RC, Gamble JA (2003) b. Felsic volcanism in the Kermadec arc, SW Pacific: crustal recycling in an oceanic setting. Geological Society, London, Special Publications 219: 99-118

Smith IEM, Worthington TJ, Price RC, Stewart RB, Maas R (2006). Petrogenesis of dacite in an oceanic subdction environment: Raoul Island, Kermadec arc. Journal of Volcanology and Geothermal Research 156: 252-265

Smith IEM, Stewart RB, Price RC, Worthington TJ (2010). Are arc-type rocks the products of magma crystallisation? Observations from a simple oceanic arc volcano: Raoul Island, Kermadec Arc, SW Pacific. Journal of Volcanology and Geothermal Research 190: 219-234

Smithers CN (1998). A Species List and Bibliography of the Insects Recorded from Norfolk Island. Technical Reports of the Australian Museum 13: 1-55

Stevens MI, Hogg ID (2003). Population genetic structure of New Zealand's endemic corophiid amphiopds: evidence for allopatric speciation. Biological Journal of the Linnean Society 81: $119-133$ 
Stilwell JD, Consoli CP, Sutherland R, Salisbury S, Rich TH, Vickers-Rich PA, Currie PJ, Wilson (2006). Dinosaur sanctuary on the Chatham Islands, Southwest Pacific: First record of theropods from the K-T boundary Takatika Grit. Palaeogeography, Paleoclimatology, Paleoecology 230: 243-250

Sukatsheva ID, Jarzembowski EA (2001). Fossil caddisflies (Insecta: Trichoptera) from the Early Cretaceous of southern Engalnd II. Cretaceous Research 22: 685-694

Swofford DL (1999). PAUP : Phylogenetic Analysis Using Parsimony (* and other methods), Version 4. Sinauer Associates, Sunderland, MA.

Tillyard RJ (1925). Caddis-flies (order Trichoptera) from the Chatham Islands. Records of the Canterbury Museum 2: 277-284

Trewick SA (1997). Flightlessness and phylogeny amongst endemic rails (Aves: Rallidae) of the New Zealand region. Philosophical Transactions of the Royal Society of London, Series B 352: 429-446

Trewick SA (2000). Molecular evidence for dispersal rather than vicariance as the origin of flightless insect species on the Chatham Islands, New Zealand. Journal of Biogeography 27: 1189-1200

Trewick SA, Goldberg J, Morgan-Richards M (2005). Fewer species of Argosarchus and Clitarchus stick insects (Phasmida, Phasmatidae): evidence from nuclear and mitochondrial DNA sequence data. Zoologica Scripta 34: 483-491

Trewick SA, Paterson AM, Campbell HJ (2007). Hello New Zealand. Journal of Biogeography 34: 16

Vink CJ, Paterson (2003). Combined molecular and morphological phylogenetic analyses of the New Zealand wolf spider genus Anoteropsis (Areneae: Lycosidae). Molecular Phylogenetics and Evolution 28: 576-587

Wagstaff SJ, Garnock-Jones PJ (1998). Evolution and biogeography of the Hebe complex (Scrophulariaceae) inferred from ITS sequences. New Zealand Journal of Botany 36: 425-437

Ward JB (1994). The New Zealand Marine Caddisflies (Trichoptera). The Weta 17: 18-20

Ward JB (1995). Nine new species of New Zealand caddis (Trichoptera). New Zealand Journal of Zoology 22: 91-103

Ward JB, Leschen RAB, Smith B, Dean JC (2004). Phylogeny of the caddisfly (Trichoptera) family Hydrobiosidae using larval and adult morphology, with the description of a new genus and species from Fiordland, New Zealand. Records of the Canterbury Museum 18: 23-43

Waters JM, McDowall RM (2005). Phylogenetics of the Australasian mudfishes: Evolution of an eellike body plan. Molecular Phylogenetics and Evolution 37: 417-425

Watt JC (1975). A General Introduction to terrestrial Arthropoda of the Kermadec Islands. The New Zealand Entomologist 6: 32-45

Weitchat W, Wichard W (1998). Atlas der Pflanzen und Tiere im Baltischen Bernstein. Dr. Freidrich Pfeil, München: 256p 
Wells A (2004). A review of Australian long-horned caddisflies in the Oecetis pechana-group (Trichoptera: Leptoceridae), with descriptions of thirteen new species. Memoirs of Museum Victoria 63: 107-128

Wise KAJ (1964). Insects of Campbell Island.Trichoptera. Pacific Insects Monograph 7: 253-254

Wise KAJ (1972).Trichoptera of the Auckland Islands. Records of the Auckland Institute and Museum 9: $253-267$

Wise KAJ (1978). Further records of subantarctic Trichoptera. Records of the Auckland Institute and Museum 10: 143-187

Wissinger SA, Sparks GB, Rouse GL (1996). Intraguild predation and cannibalism among larvae of detritivorous caddisflies in subalpine wetlands. Ecology 77: 2421-2430

Wissinger S, Steinmetz J, Alexander JS, Brown W (2004). Larval cannibalism, time constraints, and adult fitness in caddisflies that inhabit temporary wetlands. Oecologia 138: 39-47

Wood AR, Gardner JPA (2007).Small spatial scale population genetic structure in two limpet species endemic to the Kermadec Islands, New Zealand. Marine Ecology Progress Series 349: 159170

Wood, RA, Andrews PB, Herzer RH (1989). Cretaceous and Cenozoic geology of the Chatham Rise region, South Island. New Zealand Geological Survery Basin Studies 3: 1-75

Worthington TJ, Gregory MR, Bondarenko V (1999). The Denham Caldera on Raoul Volcano: dacitic volcanism in the Tonga-Kermadec arc. Journal of Volcanology and Geothermal Research 90: 29-48

Worthy TH, Hand SJ, Worthy JP, Tennyson AJD, Scofield RP (2009). A large fruit pigeon (Columbidae) from the early Miocene of New Zealand. The Auk 126: 649-656

Wright IC (1994). Nature and tectonic setting of the southern Kermadec submarine arc volcanoes; An overview. Marine Geology 118: 217-236

Wright SD, Yong CG, Dawson JW, Whittaker DJ, Gardner RC (2000).Riding the ice age El Niño? Pacific biogeography and evolution of Metrosideros subg. Metrosideros inferred from nuclear ribosomal DNA. Proceedings of the National Academy of Sciences 97: 4118-4123

Wright SD, Yong CG, Wichman SR, Dawson JW, Gardner RC (2003). Stepping stones to Hawaii: a trans-equatorial dispersal pathway for Metrosideros (Myrtaceae) inferred from nrDNA (ITS + ETS). Journal of Biogeography 28: 769-774

Wright IC, Worthington TJ, Gamble JA (2006). New multibeam mapping and geochemistry of the $30^{\circ}-35^{\circ} \mathrm{S}$ sector, and overview, of southern Kermadec arc volcanism. Journal of Volcanology and Geothermal Research 149: 263-296

Wright IC, Chadwick WW Jr., de Ronde CEJ, Reymond D, Hyvernaud O, Gennerich HH, Stoffers P, Mackay K, Dunkin MA, Bannister (2008). Collapse and reconstruction of Monwai submarine volcano Kermadec arc 1998-2004. Journal of Geophysical Research 113: B08S03, doi:10.1029/2007JB005138 
Zhou X, Jacobus LM, DeWalt RE, Adamowcz SJ, Hebert PDN (2010). Ephemeroptera, Plecoptera, and Trichoptera fauna of Churchill (Manitoba, Canada): insights into biodiversity patterns from DNA barcoding. North American Benthological Society 29: 814-83 


\section{Chapter Four: Are New Zealand's marine caddisflies a 'Ghost of Gondwana'? Phylogenetic placement of the Chathamiidae.}

\subsection{Introduction}

New Zealand biogeographically has characteristics of both a continental landmass and also an oceanic island (Cooper \& Millener 1993, Wallis \& Trewick 2009). Having broken from Gondwana over 80 million years ago the ancient subcontinent Zealandia today remains largely submerged with the major exception of modern New Zealand. New Zealand itself is often referred to as a literal 'Moa's ark' (Bellamy et al. 1990), host to ancient plants and animals argued to be of a Gondwanan or vicariant origin (e.g Fleming 1962, 1967, Stevens et al. 1988). However New Zealand is also characterised as being 'naturally depauperate but secondarily rich' (Daugherty et al. 1993) containing an unbalanced biota predominantly more indicative of long distance dispersal (Pole 1994, McGlone 2005, McDowall 2008, Goldberg et al. 2008). Although levels of endemicity are among the highest in the world; the number of endemic groups of family status or higher is much lower than would be expected of a continental landmass (Pole 1994, 2000, Macphail 1997, Gibbs 2006). It is now increasingly argued that a marine submergence during the Oligocene (roughly $23 \mathrm{Ma}$ ) known to have reduced New Zealand to at most a few islands (Fleming 1962, Cooper \& Cooper 1995), may have been total (Trewick et al. 2007, Landis et al. 2008). This raises the biogeographic concept of 'New Zealand' as a fully modern entity, biologically separate from 'Zealandia' (Campbell \& Hutching 2007, Trewick et al. 2007, Landis et al. 2008). Numerous taxa do however appear to be congruent with Gondwanan origins, for example Ratite birds, Leiopelmatid frogs, Tuatara, and and various plants and invertebrates; all now central to the debate of inferring the ancient history of New Zealand.

The five species and two genera of case-making caddisfly that comprise the Chathamiidae are among the more unusual aspects of New Zealand's fauna, being some of very few insects in the world that breeds in the marine environment. Additionally, they are one of only three insect families often considered endemic to New Zealand (Gibbs 1979, 2006, Gleeson et al. 2000, Wiegman et al. 2002, 
Kutty et al. 2010). At least two Chathamiid species are found in a small region of New South Wales, Australia, although these are both likely due to singular dispersal events from New Zealand less 20,000 years ago (Refer to Chapters Two and Three). On an evolutionary timescale, the Chathamiidae can be considered a group unique to New Zealand. The freshwater fauna of New Zealand includes many likely candidates for a vicariant Gondwanan origin, as most species are poor dispersers and many are unable to survive prolonged exposure to seawater inhibiting long distance dispersal (Gibbs 2006). Chathamiid caddisflies have the unusual distinction of being marine, although are evolved from freshwater species, thus the biogeographic inference of these groups still has relevance.

A possible ancient vicariant origin of many of freshwater groups is supported by their global distributions; many found only on the Gondwanan fragments of South America, Australia and New Zealand, which with Antarctica comprised the late Gondwanan remnant of 'Australis' (Gibbs 2006); New Zealand being the first to rift roughly 80-85 Ma (Luyendyk 1995, Sutherland 1999). A complete 'Australis' distribution is represented by four caddisfly families (de Moor \& Ivanov) four Mayfly families (Barber-James et al. 2008), four stonefly families (Fochetti \& de Figueroa 2008), the dobsonfly genus Archichauliodes (Cover \& Resh 2008), the scorpionfly family Nannochoristidae (Ferrington 2008), the dragonfly family Austropetaliidae (Kalkman et al. 2008), four genera of craneflies (de Jong et al. 2008), the dipteran subfamily Ceratomerinae (Plant 1991, Wagner et al. 2008), two families of syncarid 'shrimps' (Camacho \& Valdecasas 2008), crayfish of the Parastacidae (Crandall \& Buhay 2008) and the freshwater mussel family Hyriidae (Bogan 2008), all with representatives in New Zealand. As of yet very few of these groups have been subjected to molecular analysis, vicariant origins in New Zealand being supported for two mayfly families, and Hyriid mussels, and unsupported for one mayfly family (Ogden \& Whiting 2005, Fenwick 2006).

The caddisfly families Hydrobiosidae, Kokiriidae, Philorheithridae, Helicophidae; the subfamily Triplectidinae (Leptoceridae), and also two families not found in New Zealand; the Atriplectididae and the Tasimiidae, have distributions demonstrating an Australis pattern (Ross 1967, de Moor \& Ivanov 2008). The phylogeny of the Helicophidae was analysed by Johanson \& Keijsner (2008), who found a tree topology inconsistent with Gondwanan vicariance, with New Zealand's 
species polyphyletic; sister to species either from South America or Australia. The phylogeny of the Hydrobiosidae, represented by over at least 87 species in 10 genera endemic to New Zealand, has been subject of morphology-based taxonomy (Neboiss 1977, Ward et al. 2004), which similarly indicated a complex history difficult to assign to vicariance or dispersal alone.

Other families with possible Gondwanan roots in New Zealand include those restricted to Australasia, although some oceanic dispersal in these groups seems probable. In the trichoptera this comprises four families, the Calocidae, Conoesucidae, Oeconesidae and the Chathamiidae. Both the Calocidae and the Conoesucidae have been subject to phylogenetic analysis (Johanson et al. 2009, Johanson \& Malm 2010). Basal New Zealand relationships have been indicated in both cases possibly supporting vicariance, although at least one trans-Tasman dispersal event is demonstrated in the Conoesucidae. Five of six genera of the Oeconesidae excepting the monotypic Tascuna from Tasmania, are endemic to New Zealand. Two other taxa are also of special note. The endemic genus Alloecentrella has been of taxonomic interest, being transferred between the Bereaidae, Helicophidae and the Calocidae (Ward 1999), although the original placement in the Helicophidae is now supported (Henderson \& Ward 2007, Johanson \& Keijsner 2008, Johanson \& Malm 2010). One other endemic genus, the monotypic Rakiura is known from a disjunct distribution in North West Nelson and Stewart Island (Michaelis 1973). Rakiura vernale has importance as is the most basal member of the Helicopsychidae (the 'spiral-cased' caddisflies), the remainder of which is comprised entirely of over 192 described species of Helicopsyche with highest diversity in Australia, South-East Asia and South America, although the genus has a global distribution (de Moor \& Ivanov 2008).

Of all New Zealand's aquatic invertebrate families, only the Chathamiidae come so close to full endemic status, although the exact evolutionary relationships of the group itself remain unclear. Riek (1976) first suggested a relationship with the large and widespread family Leptoceridae (superfamily Leptoceroidea). More modern revisions of the taxonomy of the Trichoptera now place the Chathamiidae within the superfamily Sericostomatoidea, the sister grouping to the Leptoceroidea which together comprise the Brevitentoria (Weaver 1984, 1992, Frannia \& Wiggins 1997). Morphological studies have supported various topologies although a relationship between the 
Southern Sericostomatoidean families of the Calocidae, Chathamiidae, Conoesucidae and the Helicophidae is commonly suggested (Scott \& de Moor 1993, Henderson \& Ward 2007). The comprehensive phyogenies of Kjer et al. $(2000,2001)$ using $28 \mathrm{~S}$ ribosomal DNA as a conservative marker have also supported this relationship. However recent phylogenies using $16 \mathrm{~S}$ have instead indicated a possible relationship of the Chathamiidae with the Helicopsychidae and Leptoceridae in spite of the placement of the latter in a different superfamily (Johanson et al. 2009, Johanson \& Malm 2010). The status of the Leptoceroidea as a monophyletic group, although supported by Kjer et al. (2000, 2001), has also been discredited in some recent phylogenies (Frannia \& Wiggins 1997, Morse 1997, Johanson et al. 2009, Johanson \& Malm 2010).

In spite of its unclear relations, separate family status and monophyly of the Chathamiidae has been consistently supported. The Chathamiidae as revised in this Thesis comprise four species of Philanisus (one of which is currently placed in Chathamia, see Chapter 3), and the monotypic Chathamia endemic to the Chatham Islands. One molecular clock based on fossil calibrations suggests an early Cretaceous origin for the family roughly 140 Ma in age (Grimaldi \& Engel 2005); predating New Zealand's continental rifting by some 60 million years. This is almost certainly an overestimate, being partly based on a dubious early cretaceous record of a Helicophid from the purbeck beds of England (Ivanov \& Jarzembowski 2001). A Mesozoic age of origin alone does not fully support a vicariant origin however; as any taxon may have dispersed recently only become recently extinct elsewhere (Waters \& Craw 2006). Additionally the family is comprised of only five closely related species suggested to have diverged in the Pliocene roughly 4-3 Ma, an over 40-fold difference in age if an early Cretaceous origin is accepted (refer to Chapter Three of thesis). The family appears fully capable of oceanic dispersal having crossed the Tasman at least twice, and two species are found in of New Zealand's outermost island groups; the Kermadec and Chatham Islands (Riek 1976). Thus the Chathamiidae are congruent both with an ancient Gondwanan lineage, and also as a more typical recent dispersal taxon.

Although in some respects the phylogenetic placement of the Chathamiidae is well studied there is need for improved resolution. To date all phylogenetic studies have focused only on a single 
conserved marker (either 28S or 16S), supported by a number of faster evolving sequences (including COI among others). By combining data from a number of studies, and with the addition of new taxa this study aims to test the effectiveness of phylogenetic reconstruction in the Trichoptera using conserved ribosomal sequences only. Additionally, by including the basal C. brevipennis, this is the first time that the full evolutionary diversity of the Chathamiidae has been included in such a phylogeny. This will aim to help understand the phylogenetic placement of the Chathamiidae, and with the addition of fossil data this can be expanded to incorporate a relaxed molecular clock to test the hypothesis of a vicariant age for the family (> $80 \mathrm{Ma}$ ). As this analysis will explore a number of taxa, this study will also address other questions of interest, including the age and phylogenetic relationships of taxa such as Alloecentrella and Rakiura; and the relationships between the Leptoceroidea and Sericostomatoidea superfamilies.

\subsection{Materials and Methods}

\subsubsection{Taxon sampling}

This study constructed a phylogeny of the Chathamiidae and related caddisfly families using two regions (D1 and D3) of the nuclear ribosomal gene 28S, and also the mitochondrial ribosomal gene $16 \mathrm{~S}$. For this analysis a number of new sequences were developed from both marine and freshwater species collected from a number of sites around New Zealand, which included all New Zealand case-making genera with the exception of Triplectidina (Leptoceridae); Kokiria (Kokiriidae), Periwinkla (Conoesucidae); and Pseudoeconesus and Tarapsyche (Oeconesidae). Species were collected by a number of methods, including using a UV light trap or net sweeping for adults, or use of a surber net or hand searching in substrate for larvae. All specimens used in the final analysis are listed in Table 4.1

This study also incorporated sequences from a number of previous studies (Kjer et al. 2001, 2002, Johanson \& Keijsner 2008, Johanson et al. 2009, Johanson \& Malm 2010), which included both 
$16 \mathrm{~S}$ and 28S sequences for the New Zealand species Philanisus plebeius (Chathamiidae); and Pycnocentrodes aureolus and Olinga feredayi (Conoesucidae). Both sequences were present for many overseas genera, (although congeneric species had to be combined in some cases) of Sericostoma spp. (Sericostomatidae), Austreithrus spp. (Philorheithridae), Limnocentropus insolitus (Limnocentropodidae), Molanna spp. (Molannidae); and Caenota plicata and Caloca saneva (Calocidae).

DNA was extracted using a standard-phenol chloroform method, and regions of the mitochondrial genes COI and 16S, and also two regions (D1 and D3) of the nuclear gene 28S were amplified using a total of nine different primers (see Table 4.2). The COI region was amplified first and used as a DNA 'barcode' to confirm species status for some specimens, compared with data available on GenBank. The parameters for amplification have been presented in Chapter Two. DNA sequencing generally used one primer only; HCO2198 for COI, 28SD1f for 28SD1, 28SD3f for 28SD3, and 16BRH for $16 \mathrm{~S}$ although some were sequenced from both sides if retrieved data needed improved resolution. Some species were never successfully amplified in all regions and were eventually omitted from further analysis including Zelolessica (Helicophidae), Hudsonema and Oecetis (Leptoceridae), Confluens (Oeconesidae) and Pycnocentrella (Calocidae). Representatives from each family still remained in the analysis however, and these omissions were not considered significant.

All sequences used are listed in Table 4.3. For the Chathamiidae the species Philanisus plebeius and Chathamia brevipennis were used to represent both genera and the Chathamiidae as a whole. Together this dataset comprised six of the families of the Sericostomatoidea. However this excluded the Bereaidae, Anomalopsychidae, Antipodoeciidae, Barbarochthonidae, Hydrosalpingidae and the Petrothrincidae as none of these families are found in New Zealand and data for both genetic regions was not available. Some phylogenetic studies have placed almost all these families near the Chathamiidae at some point, including the Southern African Hydrosaplingidae (Scott \& de Moor 1993), the Southern African and Madagascan Petrothrincidae (Henderson \& Ward 2007), the Northern hemisphere Bereaidae (Henderson \& Ward 2007), and the South American 
Anomalopsychidae (Kjer et al. 2001); although none of these relationships are well supported. The Antipodoeciidae, represented only by the species Antipodoecia turneri from Southern Australia, have not been included in any molecular study to date although morphology does not suggest a close relationship to the Chathamiidae (Ross 1967, de Moor \& Scott 1993, Henderson \& Ward 2007, Holzenthal et al. 2007). The analysis also included three families of the Leptoceroidea (the Molannidae, Leptoceridae and the Limnocentropodidae), and finally one family of the Plenitentoria (the Oeconesidae) for use as an outgroup taxon.

\subsubsection{Alignment, phylogenetic analysis and molecular clock.}

Sequences were aligned in CLUSTALX algorithm in MEGA V 4 (Kumar et al. 2007, 2008), using default parameters and with finer scale editing by eye. All sequences had large number of insertions, thus some regions could not be aligned with certainty and were removed from analysis. Each of the three regions were analysed separately and concatenated using the model selection software jMODELTEST (Posada 2008), selecting a GTR + G (General time reversal model + Gamma) in all cases. The dataset was run in the phylogenetic software MrBayes 3.1 (Heulsenbeck \& Ronquist 2001, Ronquist \& Huelsenbeck 2003) using a total of 10,000,000 generations sampled every 10,000 to gain a total of 1,000 trees. The first $25 \%$ of the trees were discarded as a burn-in phase and the remainder used to estimate the posterior probabilities.

To test for a clock-like evolution of the gene sequences and possible gene saturation, the dataset was analysed using the phylogenetic software DAMBE (Data Analysis in Molecular Biology and Evolution, Xia 2001, Xia \& Xie 2001). The likelihood ratio test used a base tree generated by neighbour-joining with use of a GTR model and the Oeconesidae as an outgroup. Taxa were sampled for use in a Relative Rates test, which included two sister species and their nearest outgroup as inferred by the Bayesian analysis, and was repeated using random sequences throughout the tree. To further test for saturation, a false test of substitution saturation was also run (Xia et al. 2003, Xia \& Lemey 2009). 
The software BEAST v1.6.1. (Drummond \& Rambaut 2007) was used to implement a molecular clock on the data. Parameters were set using a GTR + G model and a Yule speciation model. A molecular clock was run using a relaxed uncorrelated lognormal estimate, with prior age estimates given normal distributions \pm standard deviation (see below for calibrations used). The Bayesian analysis was run using $10,000,000$ generations with a sample frequency of 10,000 , with the first $25 \%$ discarded as a burn-in phase. The log file was then also reviewed in Tracer v. 1.5.

For calibration points a fossil identified as being from the Helicophidae from the Purbeck beds of England (140 Ma) was used (Shukatsheva \& Jarzembowski 2001). However the association with the Helicophidae is dubious as the family is otherwise known only from the Southern Hemisphere, and other Northern hemisphere fossils of the family have since been ascribed to the extant northern hemisphere family Sericostomatidae (Wietchat \& Wichard 1998). This point was therefore used as a node calibration for the origin of the Seriocostomatoidea, assumed as representing the oldest known record of a caddisfly from this group. For a second calibration point a Cretaceous fossil of a larval Leptoceridae from the Baissa deposit of Siberia was used, dated at roughly $135 \mathrm{Ma}$ (Grimaldi \& Engel 2005, Ivanov 2006). This age was used as the estimate for most recent common ancestor of the Leptoceridae and its nearest sister taxon as inferred from the prior bayesian phylogeny. The geological age of the Leptocerid fossil source strata is less certain than that of the 'Helicophid' (Rasnitystn \& Zherikhin 2002) therefore these groups were given normal distribution prior estimates with standard deviations of 20 and 5 million years respectively. Also due to the taxonomic uncertainty of the Helicophid fossil, the analysis was also run using the Leptocerid fossil only. A smaller deviation of only 10 million years was used in this instance, here being the only calibration point available. Although the possible 'correct' sister taxon to the Leptoceridae was not included (such as the Calamoceratidae), this would presumably only allow for an underestimation of the age of the last common ancestor. 


\subsection{Results}

\subsubsection{Phylogenetic Analysis}

The final Bayesian tree is shown in Fig 1.1. Here monophyly of the Chathamiidae was supported, and was strongly indicated to be sister group to a monophyletic Conoesucidae $(99.999 \%$ Bayesian posterior support). This in turn was shown likely to be related to the Helicophidae and the Calocidae together comprising a clade. However this group was also suggested to contain the Molannidae, a Leptoceroidean family. Placement of Alloecentrella in the Helicophidae and Rakiura in the Helicopsychidae were supported. The Sericostomatidae was suggested as basal to other Sericostomatoidean families, and the Leptoceridae and the Philorheithridae were suggested sister taxa (the common ancestor of the latter group were used for fossil calibration). Basal position of the Oeconesidae, shown to comprise a closely related monophyletic group, was also supported.

\subsubsection{Molecular Clock \& Saturation Tests}

The likelihood ratio test found a non-significant result $(\mathrm{P}=0.0613,>0.01)$, thus all taxa are assumed an equidistance from the root of the tree, congruent with a constant evolutionary rate. All relative rates test consistently returned non-significant $\mathrm{P}$-values also supporting this result. The false test of substitution saturation returned a significant P-value $(<0.01)$ and showed an ISS value of 0.1016 and an ISSC of 0.7285 . The ISS < ISSC relationship with the significant P-value indicated little saturation, and indicated a genetic sequence useful for phylogenetic purposes.

Of the two Bayesian trees inferred in BEAST, the tree using both calibration dates (see methods) showed younger (and more conservative) ages than that using only the Leptoceridae which were both older and also more variable. Therefore the tree using both calibrations was used, shown in Fig. 4.2. As inferred in Tracer, the Chathamiidae diverged from the Conoesucidae roughly $93.5 \mathrm{Ma}$ (95\% HPD range of 73-119.5 Ma), and Chathamia and Philanisus are inferred to have diverged 30 Ma (95\% HPD range of 13-53 Ma). Other ages include a divergence of the Conoesucidae at $65 \mathrm{Ma}$ 
(95\% HPD range of 41-83 Ma), a divergence of Helicopsyche and Rakiura at $80 \mathrm{Ma}$ (95\% HPD range of 56-108 Ma), a divergence of the Helicophidae and Calocidae at $80 \mathrm{Ma}$ (95\% HPD range of 57-105 Ma), and a divergence of Philorheithrus and Austreithrus at 64 Ma (95\% HPD range of 34-91 Ma).

\subsection{Discussion}

The phylogeny found in this study generally showed robust Bayesian support and is consistent with previous genetic and morphological based phylogenies. The only feature that stood out as unusual was the placement of the Molannidae well within the Sericostomatoidea. This is almost certainly an artefact of long-branch attraction or issues with DNA alignment, as the Molannidae are known to be closely related to the Leptoceridae, strongly demonstrated both by morphological and genetic evidence (eg. Scott \& de Moor 1993, Kjer et al. 2001, 2002, Johanson \& Malm 2010). Placement of Alloecentrella and Rakiura within the Helicophidae and Helicopsychidae respectively was supported. Most relevant to this study in particular was the strongly supported relationship (Bayesian support of almost 100\%) between the Conoesucidae and the Chathamiidae. This group in turn (if the Molannidae are then excluded) was sister to clade containing the Helicophide and the Calocidae. Using the characters listed by Henderson \& Ward (2007), the Conoesucidae and Chathamiidae share some larval morphological features not found in the Helicophidae and Calocidae. These include the presence of branched abdominal gills and a quadrangular ventral apotome (sclerotized plates under the head); opposed to simple or absent gills, and a triangular apotome in the Helicophidae and Calocidae. Other common features, including those of the adults are generally shared between all four families.

A probable close relationship of these families has been indicated in the past; however this particular topology is new to this study. For example a basal Helicophidae and a ConoesucidaeCalocidae relationship (Johanson \& Keijsner 2008, Johanson et al. 2009, Johanson \& Malm 2010), a basal Conoesucidae and a Chathamiidae-Helicophidae relationship (Henderson \& Ward 2007), and a 
Chathamiidae-Calocidae relationship (Scott \& de Moor 1993) have been demonstrated. None have demonstrated monophyly per se however; the clade containing these four families has also been inferred to include the Sericostomatidae, Petrothrincidae and Anomalopsychidae among others, although a close relationship to any other specific family has not been repeatedly supported. However as several families were not included in this phylogeny, the implications of a more thorough phylogeny to the topology found here must be considered. Other points in the tree include the basal position of the Sericostomatidae, followed by the Helicopsychidae, and also a sister grouping of the Philorheithridae and the Leptoceridae.

The molecular clock found an age of the Chathamiidae consistent with a vicariant origin, with the age of the last common ancestor of the Chathamiidae and the Coneoseucidae dated at roughly 94 Ma (mean age, total distance of 73-113 Ma). The molecular clock also estimated a wide range of ages for the divergence of Philanisus and Chathamia, between 53-13 Ma (mean $30 \mathrm{Ma}$ ). This has implications considering the endemicity status of Chathamia to the Chatham Islands which are likely no older than Pleistocene in age, and conflicts with the assumed Pliocene age of the taxon ( 3Ma) estimated in Chapter Three. It may be that Chathamia represents an old taxon now extinct in mainland New Zealand, the clock is wholly innacurate, or that the molecular clock used here is inappropriate for estimating more recent divergences.

Although the age of the Chathamiidae may seem to agree with New Zealand's rifting from Australia, is important to note that the inferred closest taxon to the Chathamiidae, the Coneosucidae, is well represented in New Zealand. A prior phylogeny of the Conoesucidae indicated at least three clades, one wholly New Zealand, one wholly Australian and one found in both regions (Johansen et al. 2009). This study included taxa representative of all these groupings, and although a Cretaceous divergence of extant taxa was indicated, an age of these diversions congruent with vicariance was not well supported (83-43 Ma, mean $65 \mathrm{Ma}$ ). New Zealand or Australian origins for the Conoesucidae both remain possibilities, although Johansen et al. (2009) assumed a New Zealand origin to be more parsimonious as the arrangement of the clades weakly suggested New Zealand's species to form an ancestral paraphyly, also supported here. If the Conoesucidae and the Chathamiidae comprise a clade 
of New Zealand origin, this may have implications as the inferred age of this group diverging from the Calocidae and Helicophidae is indicated 133-89 Ma in age (mean $114 \mathrm{Ma}$ ), predating New Zealand's continental age somewhat (although the lower estimates are compatible).

It is possible that the fossil calibrations in this study were overestimates. The fossil used to date the node of the Sericostomatoidea was based on some incomplete fossilised wings from near the Jurassic-Cretaceous boundary, and may represent an unrelated taxon. However, a late Jurassic origin of the Sericostomatoidea may have to be expected if the group's biogeography is inferred to reflect continental drift. All families, perhaps excepting the cosmopolitan Helicopsychidae are restricted either to Africa and Madagascar (Barbarochthonidae, Petrothrincidae, Hydrosalpingidae); Eurasia(Beraeidae, Sericostomatidae); or the 'Australis' regions of Australia, South America, New Zealand and New Caledonia (Anomalopsychidae, Antipodoeciidae, Calocidae, Chathamiidae, Conoesucidae, Helicophidae). Pangea and Gondwana (then including Africa) did not fully separate until the late Jurassic, followed by Africa then separating in the Mid-Cretaceous opening the South Atlantic (Golonka \& Bocharova 2000, Jokat et al. 2003). Although biogeography may suggest continental vicariance, monophyly of each geographic grouping is currently equivocal, although weakly indicated in some cases (e.g. Kjer et al. 2002).

An alternative possibility is that Gondwanan India may have transported the Sericostomatidae and Beraeidae into Eurasia, by which the Sericostomatoidea may have reached its present distribution more recently. However this seems unlikely as a fossil attributed to the Sericostomatidae is described from Baltic amber roughly late Creatceous in age (Botosaneanu \& Wichard 1983, Wietchat \& Wichard 1998) and India did not reach Eurasia until the late Cenozoic (Ali et al. 2008). Additionally the role of extinction cannot be discredited, as many contemporary 'Gondwanan' taxa are well represented by Mesozoic fossils in Laurasia, such as the conifer genus Araucaria (Kunzmann 2007). Mesozoic fossils with affinities to the Calocidae, Helicophidae and Coneoesucidae are known from Europe, although their placement within any of these families is dubious (Botosaneanu \& Wichard 1983). The historical biogeography of the Sericostomatoidea is an exciting prospect for further research, however is not within the scope of this particular study. 
Other ages include the divergence of Austreithrus and Philorheithrus as roughly Paleocene in age ( $60 \mathrm{Ma})$. The Philorheithridae have a current distribution indicative of Gondwanan continental drift, restricted to Australia, New Zealand, South America and also possibly Madagascar (Weaver et al. 2008). However the age here suggests that New Zealand's lineage is unlikely to reflect vicariance, although this prospect cannot be rejected (a maximum age of 92 Ma was suggested). However, only two genera of the total nine were used. Various morphological features shared between Philorheithrus and other members of the family are absent in Austreithrus, thus the two genera are unlikely to be closely related (Henderson \& Ward 2006), in which case an even more recent age of Philorheithrus would be demonstrated.

By contrast, a vicariant age of New Zealand's endemic Rakiura was supported (56-108 Ma in age, with mean age of $80 \mathrm{Ma}$ ). Rakiura is almost certainly the most basal member of the Helicopsycidae or the 'snail-cased' caddisflies. The only other genus, Helicopsyche, is found worldwide and comprises roughly 250 known species including seven in New Zealand (Johanson 2001, Holzenthal et al. 2007). Helicopsyche contains a total of six subgenera, one restricted to Australasia (Saotrichia) one to South America (Cochilopsyche), one to Madagascar and the Seychelles (Petrotricia), one to the Americas (Feropsyche), and two (Galopsyche and Helicopsyche) to the Palearctic and Oriental regions (Johanson 1998). Helicopsyche attributable to Feropsyche are known from Dominican amber (Johanson \& Wichard 1996, Weaver 2007), indicating by roughly 2025 Ma all subgenera were well established (Poinar \& Poinar 1999). It is plausible the common ancestor of Rakiura and Helicopsyche was found on Gondwanan 'Australis', with Helicopsyche evolving on South America and Australia and later dispersing elsewhere, including to New Zealand. However this argument may be weakened as the Helicopsychidae is possibly more closely related to the Northern Sericostomatidae and Beraeidae than the other supposedly 'Gondwanan' families (Scott \& de Moor 1993, Kjer et al. 2002), although not evidenced in this study. Again, considerable further study is needed.

This study set out to explore the phylogenetic affiliations of the Chathamiidae and to test if its evolutionary age was congruent with a Gondwanan origin in New Zealand. Here a Chathamiidae 
Conoesucidae sister relationship was well supported. Molecular clock estimates did find an age close to the geological rifting in New Zealand, however the possibility of the taxon to have gone extinct elsewhere, as with many of New Zealand's other ancient plants and animals, will always remain a distinct possibility (Waters \& Craw 2006). Overall the Chathamiidae and indeed many closely related caddisflies represent a fascinating, largely untapped group for extensive historical biogeographical study, in New Zealand and worldwide. It is concluded here that the evidence supports the Chathamiidae representing a taxon of a vicariant Gondwanan origin, and significantly predates the Oligocene submergence of New Zealand. 


\subsection{Figures}

TABLE 4.1) List of all specimens used in this study for use of new sequences.

\begin{tabular}{|c|c|c|c|c|c|c|c|}
\hline Species & Family & Code & Collector & Ontogeny & Location & Date & Coordinates \\
\hline Oeconesus maori & Oeconesusidae & OEC2 & Alex Boast & Adult & Pukerua Bay & 26/03/2009 & $41^{\circ} 02^{\prime} 15 \mathrm{~S}, 174^{\circ} 53^{\prime} 12 \mathrm{E}$ \\
\hline Zelandopsyche ingens & Oeconesusidae & ZE101 & Ian Henderson & Larva & - & $15 / 01 / 2008$ & - \\
\hline Zepsyche acinaces & Oeconesusidae & ZP101 & Ian Henderson & Adult & Tangarakau Gorge & - & - \\
\hline Triplectides dolichos & Leptoceridae & LE202 & Ian Henderson & Adult & Mauatotara Falls & $9 / 02 / 2008$ & - \\
\hline Philorheithrus sp. & Philorheithridae & PS101 & Alex Boast & Larva & St. Arnaud Ranges & - & $41^{\circ} 51^{\prime} 15 \mathrm{~S}, 172^{\circ} 52^{\prime} 60 \mathrm{E}$ \\
\hline Alloecentrella magnicornis & Helicophidae & AL2 & Ian Henderson & Adult & Tangarakau Gorge & 29/01/2010 & - \\
\hline Bereaoptera roria & Conoesucidae & BE201 & Alex Boast & Larva & Ohakune & $2 / 09 / 2009$ & $39^{\circ} 24 ; 09 \mathrm{~S}, 175^{\circ} 24^{\prime} 41 \mathrm{E}$ \\
\hline Pycnocentria evecta & Conoesucidae & PC6 & Alex Boast & Larva & Ohakune & $1 / 09 / 2009$ & $39^{\circ} 25^{\prime} 19 \mathrm{~S}, 175^{\circ} 24^{\prime} 47 \mathrm{E}$ \\
\hline Helicopsyche albecens & Helicopsychidae & HE201 & Alex Boast & Larva & Ohakune & $2 / 09 / 2009$ & $39^{\circ} 24 ; 09 \mathrm{~S}, 175^{\circ} 24^{\prime} 41 \mathrm{E}$ \\
\hline Rakiura vernale & Helicopsychidae & RV101 & Alex Boast & Larva & Westhaven & $25 / 02 / 2010$ & $40^{\circ} 36^{\prime} 43 \mathrm{~S}, 172^{\circ} 34^{\prime} 37 \mathrm{E}$ \\
\hline
\end{tabular}

TABLE 4.2) List of all primers used for amplification and sequencing.

\begin{tabular}{|c|c|c|c|}
\hline Gene/Region & Primer Name & Primer sequences $\left(5^{\prime}\right.$ - 3') & Reference \\
\hline COI & $\mathrm{HCO} 2198$ & TAAACTTCAGGGTGACCAAAAAATCA & Folmer et al. 1994 \\
\hline COI & LCO1490 & GGTCAACAAATCATAAAGATATTGG & Folmer et al. 1994 \\
\hline $16 \mathrm{~s}$ & 16sARL & CGCCTGTTTATCAAAAACAT & Palumbi 1996 \\
\hline $16 \mathrm{~s}$ & $16 \mathrm{sBRH}$ & CCGGTCTGAACTCAGATCACGT & Palumbi 1996 \\
\hline 28S D1 & 28SD1f & GGAGGAAAAGAAACTAACAAGGATT & Kjer et al. 2002 \\
\hline 28S D1 & 28SD1r & CAACTTTCCCTTACGGTACT & Kjer et al. 2002 \\
\hline 28S D3 & 28SD3f & ACCCGTCTTGAAACACGGAC & Kjer et al. 2002 \\
\hline 28S D3 & 28SD3r1 & ATTCCCCTGACTTCGACCTGA & Kjer et al. 2002 \\
\hline 28S D3 & 28SD3r2 & CTATCCTGAGGGAAACTTCGGA & Kjer et al. 2002 \\
\hline
\end{tabular}


TABLE 4.3) List of all sequences used in this study. References: 1 Kjer et al. (2001), 2 Hayashi et al. (2008), 3 Johanson et al. (2009), Johanson \& Keijsner (2008), 5 Johanson \& Malm (2010)

\begin{tabular}{|c|c|c|c|c|c|}
\hline Genus/Species & Family & Biogeography & $\begin{array}{l}\text { Source } \\
16 \mathrm{~S} \\
\end{array}$ & 28SD1 & 28SD3 \\
\hline Oeconesus maori & Oeconesidae & New Zealand & This study & $1 \mathrm{AF} 436174$ & $1 \mathrm{AF} 436295$ \\
\hline Zelandopsyche ingens & Oeconesidae & New Zealand & This study & This study & This study \\
\hline Zepsyche acinaces & Oeconesidae & New Zealand & This study & This study & This study \\
\hline Triplectides dolichos & Leptoceridae & New Zealand & This study & This study & This study \\
\hline Limnocentropus insolitus & Limnocentropodidae & Japan & 2 AB365798 & $1 \mathrm{AF} 436175$ & $1 \mathrm{AF} 436296$ \\
\hline Molanna angustata/uniophila & Molannidae & Europe & 3 FJ263197 & $1 \mathrm{AF} 436201$ & $1 \mathrm{AF} 436321$ \\
\hline Austrheithrus glymalronewa & Philorheithridae & Australia & 3 FJ263221 & $1 \mathrm{AF} 436207$ & $1 \mathrm{AF} 436327$ \\
\hline Philorheithrus sp. & Philorheithridae & New Zealand & This study & This study & This study \\
\hline Alloecentrella magnicornis & Helicophidae & New Zealnad & 4 EF394983 & This study & This study \\
\hline Caenota plicata & Calocidae & Australia & 4 EF395003 & $1 \mathrm{AF} 436191$ & $1 \mathrm{AF} 436311$ \\
\hline Caloca saneva & Calocidae & Australia & 5 FN257670 & $1 \mathrm{AF} 436195$ & $1 \mathrm{AF} 436315$ \\
\hline Chathamia brevipennis & Chathamiidae & Chatham Island & This study & This study & This study \\
\hline Philanisus plebeius & Chathamiidae & Australasia & 3 FJ263205 & $1 \mathrm{AF} 436196$ & $1 \mathrm{AF} 436316$ \\
\hline Bereaoptera roria & Conoesucidae & New Zealand & 3 FJ263202 & This study & This study \\
\hline Costora delora & Conoesucidae & Australia & 4 EF395004 & $1 \mathrm{AF} 436192$ & $1 \mathrm{AF} 436312$ \\
\hline Olinga feredayi & Conoesucidae & New Zealand & 4 EF394980 & $1 \mathrm{AF} 436194$ & $1 \mathrm{AF} 436314$ \\
\hline Pycnocentria evecta & Conoesucidae & New Zealand & 3 FJ263199 & This study & This study \\
\hline Pycnocentrodes aureolus & Conoesucidae & New Zealand & 3 FJ263198 & $1 \mathrm{AF} 436193$ & $1 \mathrm{AF} 436313$ \\
\hline Alloecella grisea & Helicophidae & Australia & 4 EF395006 & $1 \mathrm{AF} 436181$ & $1 \mathrm{AF} 436302$ \\
\hline Helicopsyche albecens & Helicopsychidae & New Zealand & 4 EF394986 & This study & This study \\
\hline Rakiura vernale & Helicopsychidae & New Zealand & 4 EF394976 & This study & This study \\
\hline Sericostoma clypeatum / sp. & Sericostomatidae & Europe & 3 FJ263207 & $1 \mathrm{AF} 436185$ & $1 \mathrm{AF} 436306$ \\
\hline
\end{tabular}




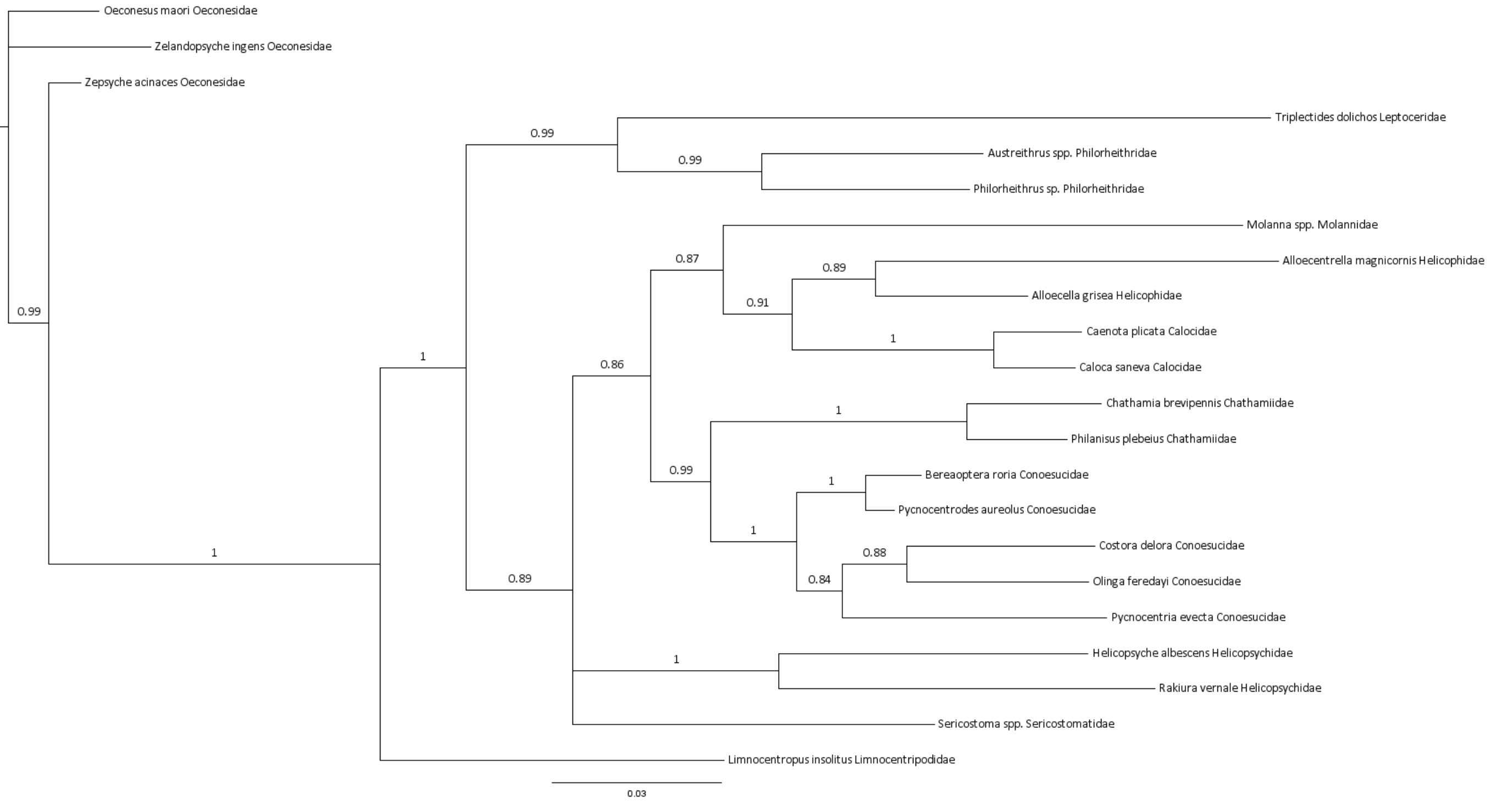

FIG 4.1) Bayesian analysis tree as inferred through MrBayes. Posterior Bayesian probability indices are shown. 


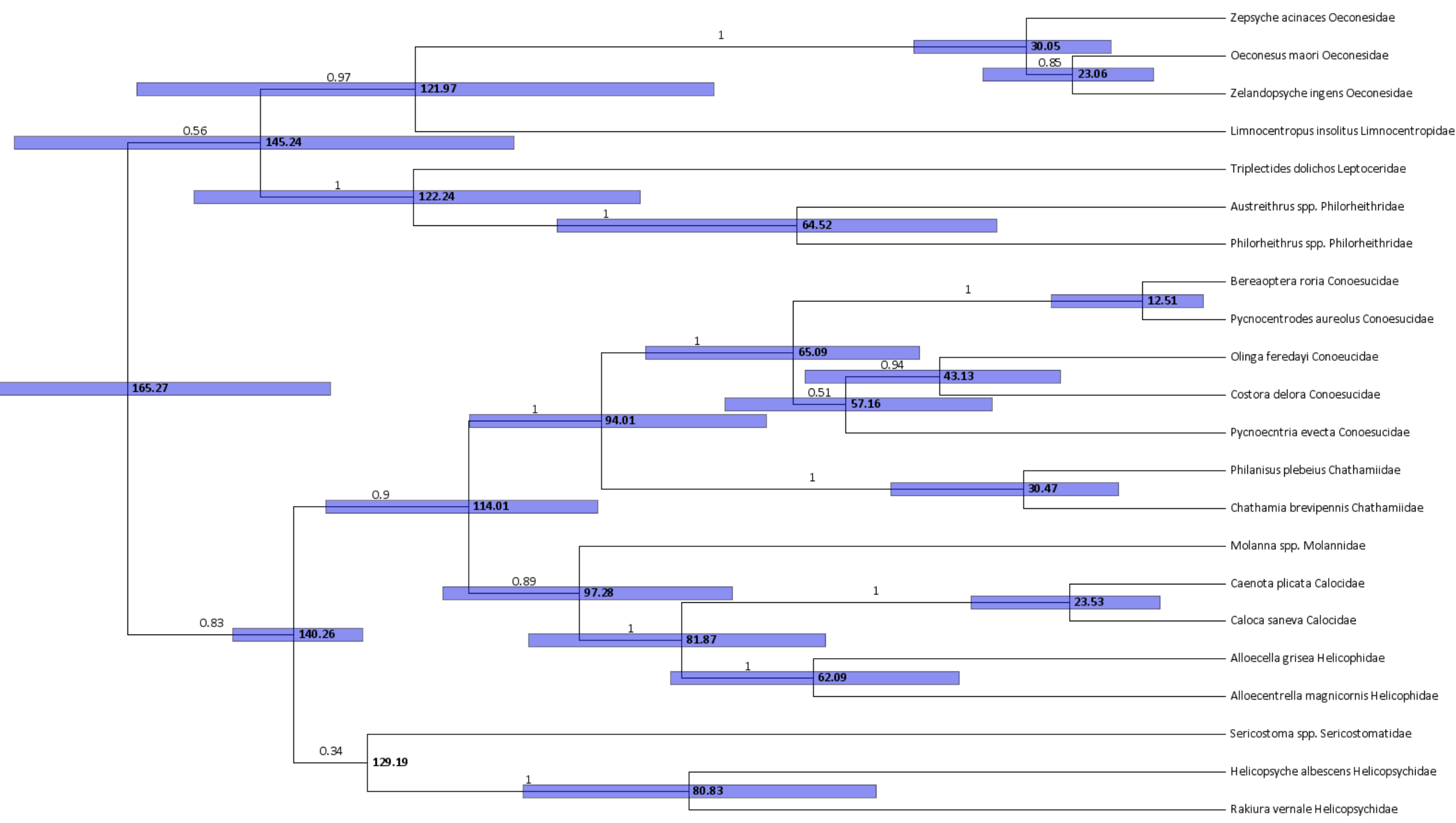

FIG 4.2) Bayesian analysis as run through BEAST with molecular clock estimates shown. Posterior probabilites shown on left of nodes, and estimated age in bold (in Ma). Bars show 95\% HPD. 


\subsection{References:}

Ali JR, Aitchison JC (2008). Gondwana to Asia: Plate tectonics, paleogeography and the biological connectivity of the Indian sub-continent from the Middle Jurassic through latest Eocene (166$35 \mathrm{Ma})$. Earth-Science Reviews 88: 166-35

Barber-James HM, Gattolliat JL, Sartori M, Hubbard MD (2008).Global diversity of mayfleis (Ephemeroptera, Insecta) in freshwater. Hydrobiologia 595: 339-350

Bellamy DJ, Spingett B., Hayden P. (1990). Moa's ark: The voyage of New Zealand. Viking, New York, $231 \mathrm{pp}$

Bogan AE (2008). Global diversity of freshwater mussels (Mollusca, Bivalvia) in freshwater. Hydrobiologia 595: 139-147

Botosaneanu L, Wichard W (1983). Upper-Cretaceous Amber Trichoptera. In: Morse JC (editor), Proceedings of the fourth International Symposium on Trichoptera pp 43-49. Dr W. Junk Publishers, The Hague.

Campbell HJ, Hutching G (2007). In Search of Ancient New Zealand. Penguin Books, London.

Cooper A, Cooper RA (1995). The Oligocene Bottleneck and New Zealand Biota: Genetic Record of a past Environmental Crisis. Philosophical Proceedings of the Royal Society of London, Series B: Biological Sciences 261: 293-302

Cooper RA, Millener PR (1993). The New Zealand Biota; Historical Background and New Research. TRENDS in Ecology and Evolution 8: 429-433

Cover MR, Resh VH (2008). Global diversity of dobsonflies, fishflies and alderflies (Megaloptera; Insecta) and spongillaflies, nevrorthids and osmylids (Neuroptera; Insecta) in freshwater. Hydrobiologia 595: 409-417

Crandall KA, Buhay JE (2008). Global diversity of crayfish (Astacidae, Cambaridae, and Parastacidae - Decapoda) in freshwater. Hydrobiologia 595: Global diversity of crayfish (Astacidae, Cambaridae, and Parastacidae - Decapoda) in freshwater. Hydrobiologia 595: 295-301

Daugherty CH, Gibbs GW, Hitchmough RA (1993). Mega-Island of Micro-Continent? New Zealand and Its Fauna. TRENDS in Ecology and Evolution 8: 437-442

de Moor FC, Ivanov VD (2008). Global diversity of caddisflies (Trichoptera: Insecta) in freshwater. Hydrobiologia 595: 393-407

Drummond AJ, Rambaut A (2007). BEAST: Bayesian evolutionary analysis by sampling trees. BMC Evolutionary Biology 7: 214

Fenwick M. (2006). The molecular phylogenetics of the New Zealand freshwater mussels. Msc Thesis, Victoria University of Wellington.

Ferrington LC Jr. (2008). Global biodiversity of Scorpionflies and Hangingflies (Mecoptera) in freshwater. Hydrobiologia 595: 443-445 
Fleming CA (1962). New Zealand Biogeography. A paleontologist's approach. Tuatara 10: 53-108

Fleming CA (1979). The Geological History of New Zealand and its life. Auckland University Press, $141 \mathrm{pp}$

Fochetti R, de Figueroa JMT (2008). Global diversity of stoneflies (Plecoptera; Insecta) in freshwater. Hydrobiologia 595: 365-377

Frania HE, Wiggins G.B (1997). Analysis of morphological and behavioural evidence for the phylogeny of and higher classification of Trichoptera (Insecta). Royal Ontario Museum Life Sciences Contributions 160: 1-67

Gibbs GW (1979). Some Notes on the Biology and Status of the Mnesarchaeidae (Lepidoptera). New Zealand Entomologist 7: 193-200

Gibbs G (2006). Ghosts of Gondwana: a history of life in New Zealand. Craig Potton Publishing, Nelson.

Gleeson DM, Howitt RLJ, Newcomb RD (2000). The phylogenetic position of the New Zealand batfly, Mystacinobia zelandica (Mystacinobiidae; Oestroidea) inferred from mitochondrial $16 \mathrm{~S}$ ribosomal DNA sequence data. Journal of the Royal Society of New Zealand 30: 155-168

Goldberg J, Trewick SA, Paterson AM (2008). Evolution of New Zealand's terrestrial fauna: a review of molecular evidence. Philosophical Proceedings of the Royal Society of London, Series B: Biological Sciences 363: 3319-3334

Golonka J, Bocharova NY (2000).Hot spot activity and the break-up of Pangea. Palaeogeography, Palaeolimatology, Palaeoecology 161: 49-69

Grimaldi D, Engel MS (2005). Evolution of the Insects. Cambridge University Press, New York.

Hayashi F, Kamimura Y, Nozaki T (2008). Origin of the Transition from Aquatic to Terrestrial Habits in Nothopsyche Caddisflies (Trichoptera: Limnephilidae) Based on Molecular Phylogeny. Zoological Science 25: 255-260

Henderson IM, Ward JB (2006). Four new species of the caddis genus Philorheithrus (Trichoptera: Philorheithridae) from New Zealand. Records of the Canterbury Museum 20: 21-33

Henderson IM, Ward JB (2007).Three new species in the endemic New Zealand genus Alloecentrella (Trichoptera), and a re-evaluation of its family placement. Aquatic Insects 29: 79-96

Huelsenbeck JP, Ronquist F (2001). MRBAYES: Bayesian inference of phylogenetic trees. Bioinformatics 17: 754-755

Ivanov VD (2006). Larvae of Caddisflies (Insecta: Trichoptera) from the Mesozoic of Siberia. Paleontological Journal 40: 178-189

Johanson KA (1998). Phylogenetic and biogeographic analysis of the family Helicopsychidae (Insecta: Trichoptera). Entomologica Scandinavica, Supplement 53: 1-172

Johanson KA (2001). Phylogenetic and biogeographical analysis of the New Zealand Helicopysche von Siebold (Trichoptera: Helicopsychidae). Insect Systematics and Evolution 32: 107-120 
Johanson KA, Keijsner M (2008). Phylogeny of the Helicophidae (Trichoptera), with emphasis on the New Caledonian species of Helicopha. Systematic Entomology 33: 451-483

Johanson KA, Kjer K, Malm T (2009). Testing the monophyly of the New Zealand and Australian endemic family Conoesucidae Ross based on combined molecular and morphological data (Insecta: Trichoptera: Sericostostomatoidea). Zoologica Scripta 38: 563-573

Johanson KA, Malm T. (2010). Testing the monophyly of Calocidae (Insecta: Trichoptera) based on multiple molecular data. Molecular Phylogenetics and Evolution 54: 535-541

Johanson KA, Wichard W (1996). Caddis flies of Dominican amber X. Fossil species of Helicopsyche (Trichoptera). Mitteilungen aus dem Geoloogische-Paläontologischen Institut der Universität Hamburg 79: 195-209

Jokat W, Boebel T, König M, Meyer W (2003). Timing and geometry of early Gondwana breakup. Journal of Geophysical Research 108: 2438

Kalkman VJ, Clausnitzer V, Dijkstra KDB, Orr AG, Paulson DR, van Tol J (2008). Global diversity of dragonflies (Odonata) in freshwater. Hydrobiologia 595: 351-363

Kjer KM, Blahnik RJ, Holzenthal RW (2001). Phylogeny of Trichoptera (Caddisflies): Characterization of Signal and Noise within Multiple Datasets. Systematic Biology 50: 781-816

Kjer KM, Blahnik RJ, Holzenthal RW (2002). Phylogeny of Caddisflies (Insecta, Trichoptera). Zoologica Scripta 31: 83-91

McKnight D.G. (1968). Some Echinoderms from the Chatham Islands. New Zealand Journal of Marine and Freshwater Research 2: 505-526

Kumar K, Dudley J, Nei M, Kumar S (2007). MEGA4: Molecular Evolutionary Genetics Analysis software version 4.0. Molecular Biology and Evolution 24: 1596-1599.

Kumar K, Dudley J, Nei M, Kumar S (2008). MEGA: A biologist-centric software for evolutionary analysis of DNA and protein sequences. Briefings in Bioinformatics 9: 299-306

Kutty S, Pape T, Wiegmann BM, Meier R (2010). Molecular phylogeny of the Calyptratae (Diptera: Cyclorrhapha) with an emphasis on the superfamily Oestroidea and the position of Mystacinobiidae and McAlpine's fly. Systematic Entomology 35: 614-635

Kunzmann L (2007). Araucariaceae (Pinopsida): Aspects in palaeobiogeography and palaeobiodiversity in the Mesozoic. Zoologischer Anzeiger 246: 257-277

Landis CA, Campbell HJ, Begg JG, Mildenhall DC, Paterson AM, Trewick SA (2008). The Waipounamu Erosion Surface: questioning the antiquity of the New Zealand land surface and terrestrial fauna and flora. Geological Magazine 145: 173-197

Luyendyk B.P. (1995). Hypothesis for Cretaceous rifting of east Gondwana caused by subducted slab capture. Geology 23: 373-376

Macphail MK (1997). Comment on M. Pole (1994): 'The New Zealand Flora-Entirely Long-Distance Dispersal?' Journal of Biogeography 24: 113-117 
Michaelis FB (1994). The life history of Rakiura vernale (Trichoptera: Helicopsychidae). Journal of the Royal Society of New Zealand 3: 295-304

McGlone MS (2005). Goodbye Gondwana. Journal of Biogeography 32: 345-351

Neboiss A (1977). A taxonomic and zoogeographic study of Tasmanian caddis-flies (Insecta: Trichoptera). Memoirs of the National Museum of Victoria 38: 1-208

Ogden T.H., Whiting MF (2005). Phylogeny of Ephemeroptera (mayflies) based on molecular evidence. Molecular Phylogenetics and Evolution 37: 625-643

Plant AR (1991). A revision of the genus Ceratomerus (Diptera: Empididae: Ceratomerinae) of New Zealand. Journal of Natural History 25: 1313-1330

Poinar GO, Poinar R (1999). The Amber Forest: A Reconstruction of a Vanished World. Princeton University Press.

Pole M (1994). The New Zealand Flora-Entirely Long-Distance Dispersal? Journal of Biogeography 21: $625-635$

Pole MS (2001). Can long-distance dispersal be inferred from the New Zealand plant fossil record? Australian Journal of Botany 49: 357-366

Posada D (2008). jModelTest: Phylogenetic Model Averaging. Molecular Biology and Evolution 25: 1253-1256.

Rasnitsyn AP, Zherikhin VV (2002). Alphabetic Lists of Selected Insect Fossil Sites: Impression Fossils. In: Rasnitsyn AP, Quicke LJ (editors) History of Insects. Kluwer, Dordrecht, Boston, London, pp 437-444

Riek E.F. (1976). The marine caddisfly family Chathamiidae (Trichoptera). Journal of the Australian Entomological Society 15: 405-419

Ronquist F, Huelsenbeck JP (2003). MrBayes 3: Bayesian phylogenetic inference under mixed models. Bioinformatics 19: 1572-1574

Ross HH (1967). The evolution and past dispersal of the Trichoptera. Annual Review of Entomology 12: $169-206$

Sukatsheva ID, Jarzembowski EA (2001). Fossil caddisflies (Insecta: Trichoptera) from the Early Cretaceous of southern England II. Cretaceous Research 22: 685-694

Sutherland R. (1999) a. Basement geology and tectonic development of the Greater New Zealand region: an interpretation from regional magnetic data. Tectonophysics 308: 341-362

Scott KMF, de Moor FC (1993). Three recently erected Trichoptera families from South Africa, the Hydrosalpingidae, Petrothrincidae and Barbarochthonidae (Integripalpia: Sericostomatoidea). Annals of the Cape Province Museum of Natural History 18: 293-354

Trewick SA, Paterson AM, Campbell HJ (2007). Hello New Zealand. Journal of Biogeography 34: 16 
Wagner R, Barták M, Borkent A, Courtney G, Goddeeris B, Haenni JP, Knutson L, Pont A, Rotheray GE, Rozkošný R, Sinclair B, Woodley N, Zatwarnicki T, Zwick (2008). Global diversity of dipteran families (Insecta Diptera) in freshwater (excluding Simulidae, Culicidae, Chironomidae, Tipulidae and Tabanidae). Hydrobiologia 595: 489-519

Wallis GP, Trewick SA (2009). New Zealand phylogeography: evolution on a small continent. Molecular Ecology 18: 3548-3580

Ward JB (1999). An annotated checklist of the caddis (Trichoptera) of the New Zealand subregion. Records of the Canterbury Museum 13: $32-59$

Ward JB, Leschen RAB, Smith B, Dean JC (2004). Phylogeny of the caddisfly (Trichoptera) family Hydrobiosidae using larval and adult morphology, with the description of a new genus and species from Fiordland, New Zealand. Records of the Canterbury Museum 18: 23-43

Waters JM, Craw D (2006). Goodbye Gondwana? New Zealand Biogeography, Geology, and the Problem of Circularity. Systematic Biology 55: 351-356

Weaver JS III (1984). The evolution and classification of Trichoptera, part I: the groundplan of Trichoptera. In: Morse JC (editor) Proceedings of the Fourth International Symposium of Trichoptera pp 413-419. The Hague, Junk, 486pp

Weaver JS III (1992). Further remarks on the evolution of Trichoptera: a reply to Wiggins. Cladistics 8: $187-190$

Weitchat W, Wichard W (1998). Atlas der Pflanzen und Tiere im Baltischen Bernstein. Dr. Freidrich Pfeil, München: 256p

Weaver JS III, Gibon FM, Chvojka P (2008). A new genus of Philorheithridae (Trichoptera) from Madagascar. Zootaxa 1825: 18-28

Wichard W (2007). Overview and descriptions of caddisflies (Insecta, Trichoptera) in Dominican amber (Micoene). Stuttgarter Beiträge zur Naturkunde Serie B (Geologie und Paläontologie) 366

Wiegman BM, Regier JC, Mitter C (2002). Combined molecular and morphological evidence on the phylogeny of the earliest lepidopteran lineages (2002). Zooloigca Scripta 31: 67-81

Xia X, Xie Z (2001). DAMBE: Data analysis in molecular biology and evolution. Journal of Heredity 92:371-373.

Xia X (2001).Data analysis in molecular biology and evolution. Kluwer Academic Publishers, Boston.

Xia X, Xie Z, Salemi M, Chen L, Wang Y (2003). An index of substitution saturation and its application. Molecular Phylogenetics and Evolution 26: 1-7.

Xia X, Lemey P (2009). Assessing substitution saturation with DAMBE. Pp. 615-630 in Philippe Lemey, Marco Salemi and Anne-Mieke Vandamme (editors). The Phylogenetic Handbook: A Practical Approach to DNA and Protein Phylogeny. 2nd edition Cambridge University Press. 


\section{Chapter Five: General Discussion and Conclusions.}

\subsection{Major results of this study.}

In this thesis, the evolutionary history of New Zealand's marine caddisflies, the Chathamiidae, was examined through the use of a thorough genetic analysis. Firstly an analysis was performed on the common and widespread species Philanisus plebeius from samples throughout New Zealand and also New South Wales Australia, to investigate the phylogeographic structure of this species in New Zealand and also to determine the origin of the population in Australia. Secondly, the inner phylogeny of the Chathamiidae was examined with a special emphasis on the island species Philanisus fasciatus from the Kermadec Islands, and Chathamia brevipennis from the Chatham Islands. In addition, two other species of caddisfly; Oecetis chathamensis and Hydrobiosis lindsayi from Chatham Island were also used as a comparison for $C$. brevipennis. Finally a family level phylogeny of the Chathamiidae and related families was undertaken, using both sequences new to this study and also drawing on data from a number of previous studies. This thesis found a number of new and interesting results in each of these chapters.

The first chapter discussing results (Chapter Two) focused entirely on Philanisus plebeius. It was found that the New Zealand population of $P$. plebeius comprised almost all of the genetic diversity found within the species; a total of 21 haplotypes in 3 identifiable haplogroups. By contrast all Australian sequences shared just one haplotype not found in New Zealand, although this differed from the dominant New Zealand haplotype by only a single base pair, and nested within one of the haplogroups identified. Based on the available genetic information, a human introduction to Australia is not supported although a recent dispersal from New Zealand since the LGM ( 20 ka ago) is largely conclusive. However a human introduction would be very strongly supported should the Australian haplotype be discovered to be resident in a New Zealand population. 
The trans-Tasman nature of the Chathamiidae was also found to be more complex than previously thought, as whilst studying P. plebeius samples from Australia a single larval sample from Sydney was found to be that of Chathamia integripennis. This again differed from a New Zealand haplotype of the species by a single base pair. The species $C$. integripennis was previously thought entirely endemic to New Zealand, and to the upper North Island in particular, so this result was wholly unexpected. It was decided that this particular result fell outside of the scope of Chapter Two and was instead discussed in the following chapter.

In New Zealand itself there was a distinct cryptic population structure found in two closely associated sites in the central eastern North Island, just south of Hawke's bay (comprising the entirety of one of the haplogroups described above), evolutionarily distinct from the remainder of the species. The northern boundary of this cryptic group was not identified, but there was found to be a discrete genetic switch of the genetic groups between Mangakuri and Whangaehu beaches, a geographic distance of just $52 \mathrm{~km}$. A number of possible hypotheses for this break were proposed, including oceanic currents, volcanism and Pleistocene climate change, however none were considered conclusive. The reasoning for this structure is still considered largely unknown, although similar patterns have been found in some marine studies (Nakano \& Spencer 2007, Nickel 2009). Overall this was the major result of this particular Chapter, and together these observations raise the possibility for this population to represent a previously unidentified cryptic species.

The remainder of Philanisus plebeius was shown to contain little genetic diversity, almost all fell within the other major haplogroup, and in turn most of these differing by only one base pair from the most common haplotype which was found throughout New Zealand. It seems probable that this haplogroup represents a radiation following the last glacial maximum, and only this grouping has successfully re-dispersed throughout the remainder of New Zealand. It seems likely that during the glacial cycles, environmental limitations restricted the species largely to the North of New Zealand although more evidence from this region is needed to support this fully. This radiation event also included the single haplotype found in Australia. There was a single sample that was found to be genetically intermediate between the two major groupings (comprising a third and final haplogroup), 
and remains somewhat enigmatic. The distribution of this haplogroup remains largely unknown, although is likely restricted to Northern New Zealand (the sequence came from one sample collected in Tauranga estuary).

The next main chapter (Chapter Three) analysed the phylogeny of the Chathamiidae and also investigated two other unrelated caddisfly species from the Chatham Islands. It was found that the Chathamiid species Chathamia integripennis from the upper North Island (and also evidently Australia, see above), was nested within the genus Philanisus. The type (and only remaining) species of Chathamia, C. brevipennis, instead formed a distant sister taxon to all the remaining Chathamiidae. It was suggested that $C$. integripennis be transferred to Philanisus, an inference that would leave Chathamia a monotypic genus endemic to the Chatham Islands.

Age estimates using strict substitution rates from Brower (1994) and Papadopoulou et al. (2010) suggested an age of roughly 3-500,000 years for the lineage represented by P. fasciatus evidencing that land has been present in the Kermadec region since the mid Pleistocene. A Pliocene age of roughly three million years for the species $C$. brevipennis was also found. However the age for C. brevipennis by relaxed molecular clock using fossil calibrations in the final main chapter (Chapter Four) suggested a minimum age of 12 million years (with a mean of 30 million years). It is unknown which clock is more accurate. However the possibility for $C$. brevipennis to represent a taxon of Pliocene age or older seems likely, possibly significant as the modern Chathams are generally considered no older than Pleistocene in age (Campbell \& Hutching 2007). This may indicate that the C. brevipennis lineage has since gone extinct in New Zealand, or that there has been continuous land in the region longer than current geological estimates suggest. There are a number of studies that do suggest Pliocene ages for at least some Chatham Island taxa (e.g. Liggins et al. 2008, Heenan et al. 2010), congruent with this finding. This study also demonstrated an early Pleistocene age for the species Hydrobiosis lindsayi, and a mid-late Pleistocene age for the species Oecetis chathamensis.

In this study only a small fragment of the gene COI was ever sequenced from the species Philanisus mataua. This sample was a museum specimen roughly 17 years in age (collected in 1993), 
and had been stored in $70 \%$ ethanol at room temperature since this time. Amplification of this sequence involved numerous attempts over several weeks, and was only successful using one new primer developed in this study (paired with the universal primer LCO1490). Another primer was developed to be paired with the universal primer HCO1498 to comprise the remainder of the sequence however was never successful. Eventually the region was successfully amplified and sequenced twice, and the data received demonstrated both times two DNA sequences within each sample (thus either contamination or a heteroplasmic sample). This comprised a total of seven such heterogenous sites, all corresponding exactly with regions either indicative with haplotypes of Philanisus plebeius or Chathamia integripennis. It is considered that $P$. mataua may therefore be a hybrid between these two species, or represents a close relative of $P$. plebeius and the data was contaminated by $C$. integripennis DNA (the reconstructed P. plebeius sample was divergent from any known P. plebieus haplotype, although still fell within the diversity exhibited by this species). New sequences of $P$. mataua are of some interest here, to see which (if either) hypothesis is correct.

The final chapter (Chapter Four) addressed the phylogenetic position of the Chathamiidae among related families and also used a relaxed molecular clock. This particular phylogeny was the first in caddisflies to combine the two ribosomal DNA sequences $28 \mathrm{~S}$ and $16 \mathrm{~S}$ in a single analysis. However the number of taxa was limited. Time constraints and amplification issues resulted in a number of taxa being omitted, in spite of having been successfully collected. Additionally families not found in New Zealand were poorly represented, as these were limited to what had been sequenced in past studies. Only by chance some genera therefore had sequences of both regions available (as opposed to species, as this phylogeny was forced to combine different congeneric species into single sequences). However the tree topology found was robust, and strongly suggested the Chathamiidae to form a sister taxon to the Australasian family Conoesucidae, in turn related to the other mostly Australasian families of the Calocidae and the Helicophidae. A molecular clock was used based on fossil calibrations, and is considered to be conservative and the dates found are thus unlikely to represent overestimates. In this case a late Cretaceous origin of the Chathamiidae was found, 
consistent with a Gondwanan origin in New Zealand. The potential of $28 \mathrm{~S}$ and $16 \mathrm{~S}$ used together to construct a robust phylogeny using a larger number of taxa is well supported.

\subsection{Limitations of this study and future research}

The limitations of this study were in most part, logistical. The phylogeography of $P$. plebeius did not include many sites in the upper North Island excepting from around Auckland and a few samples from Tauranga. No sites from the west coast of the South Island were used, and a number of geographically isolated regions (especially New Plymouth) were limited to very few samples. Additionally the use of only mitochondrial genes can lead to a biased perspective of gene flow in populations due to lineage sorting (Moore 1995). As a result future study of the phylogeographic structure of $P$. plebeius using nuclear genes would be of particular interest. Future research should include a large number of sites in the upper North Island, hypothesised in this study to provide the glacial refuge of the species and thus likely to represent most of the evolutionary diversity. Samples from the western South Island would also be of some interest although are predicted here to show very low genetic diversity, and are unlikely to possess any unique hapotypes. Wider sampling to also test for the possible gaps in the species' distribution (such as the North Eastern North Island and Stewart Island) may need to be undertaken, and also the use of a nuclear gene (such as EF-1a) should perhaps be considered. P. plebeius was well demonstrated, in spite of the limitations here, to have a high degree of interesting genetic features, and should be of interest for a much more thorough analysis. More sampling in New South Wales should also be of interest, especially to confirm or identify the distribution of $C$. integripennis there.

It is considered here that the phylogenetic relationship between the species of the Chathamiidae was robustly tested, excepting the species Philanisus mataua, from which new complete sequences are critically needed. Again no nuclear genes were used however, ignoring the effects of possible prior introgression events misleading the results, such as for example the observed 
placement of C. integripennis within Philanisus (Posada \& Crandall 2002). The family level phylogeny although finding arguably the most robust phylogenetic placement of the Chathamiidae to date, was nonetheless limited by its use of only half of the families of the Sericostomatoidea, and the use of only a few species per family. A larger scale phylogeny of case making caddisflies, or at the very least the Sericostomatoidea, incorporating several conservative genes and all families and also using a molecular clock would provide a fascinating biogeographic study regarding the presumed radiation of this group in the Mesozoic. It is also argued in this study that many more studies on the biotas of New Zealand's outermost islands are urgently needed, especially the Kermadec Islands, and also the sub-Antarctic Islands which have been subject of no phylogeographic studies to date. It is also suggested here that some of the species endemic to the Chatham Islands be selected to further provide evidence for, or against, a pre-Pleistocene age of the Chatham biota. 


\subsection{References}

Brower AVZ (1994). Rapid morphological radiation and convergence among races of the butterfly Heliconius erato inferred from patterns of mitochondrial DNA evolution. Proceedings of the National Academy of Sciences of the USA 91: 6491-6495

Campbell HJ, Hutching G (2007). In Search of Ancient New Zealand.Penguin Books, London.

Heenan PB, Mitchell AD, de Lange PJ, Keeling J, Paterson AM (2010). Late-Cenozoic origin and diversification of Chatham Islands endemic plant species revealed by analyses of DNA sequence data. New Zealand Journal of Botany 48: 83-136

Liggins L, Chapple DG, Daugherty CH, Ritchie P (2008). Origin and post-colonization evolution of the Chatham Islands skink (Oligosoma nigriplantare nigriplantare). Molecular Ecology 17: 3290-3305

Moore WS (1995).Inferring phylogenies from mtDNA variation: mitochondrial-gene trees versus nuclear-gene trees. Evolution 19: 718-726

Nakano T, Spencer HG (2007). Simultaneous polyphenism and cryptic species in an intertidal limpet from New Zealand. Molecular Phylogenetics and Evolution 45: 470-479

Nickel JE (2009).The diversity of Hippocampus abdominalis in New Zealand. MSc thesis, University of Waikato Research Commons

Papadopoulou A, Anastasiou I, Volger AP (2010). Revisiting the Insect Mitochondrial Molecular Clock: The Mid-Aegean Trench Calibration. Molecular Biology and Evolution 27: 1659-1672

Posada D, Crandall KA (2002).The effect of Recombination on the Accuracy of Phylogeny Estimation. Journal of Molecular Evolution 54: 396-40 